US Army Corps

of Engineers

Engineer Research and

Development Center

\title{
A Case History of Embankment Failure: Geological and Geotechnical Aspects of the Celotex Levee Failure, New Orleans, Louisiana
}

by Joseph B. Dunbar, Victor H. Torrey III, Lillian D. Wakeley 
The contents of this report are not to be used for advertising, publication, or promotional purposes. Citation of trade names does not constitute an official endorsement or approval of the use of such commercial products.

The findings of this report are not to be construed as an official Department of the Army position, unless so designated by other authorized documents. 


\section{A Case History of Embankment Failure: Geological and Geotechnical Aspects of the Celotex Levee Failure, New Orleans, Louisiana}

by Joseph B. Dunbar, Victor H. Torrey III, Lillian D. Wakeley

Geotechnical Laboratory

U.S. Army Engineer Research and Development Center 3909 Halls Ferry Road

Vicksburg, MS 39180-6199

Final report

Approved for public release; distribution is unlimited

Prepared for U.S. Army Engineer Division, Mississippi Valley 1400 Walnut Street

Vicksburg, MS 39180-0080

and U.S. Army Corps of Engineers Civil Works Research and Development Program Risk Analyses for Dam Safety 


\section{Army Engineer Research and Development Center Cataloging-in-Publication Data}

Dunbar, Joseph B.

A case history of embankment failure : geological and geotechnical aspects of the Celotex Levee failure, New Orleans, Louisiana / by Joseph B. Dunbar, Victor H. Torrey III, Lillian D. Wakeley ;

prepared for U.S. Army Engineer Division, Mississippi Valley and U.S. Army Corps of Engineers Civil Works Research and Development Program, Risk Analyses for Dam Safety.

114 p. : ill. ; 28 cm. - (Technical report ; GL-99-11)

Includes bibliographic references.

1. Embankments - Louisiana - New Orleans. 2. Levees - Louisiana - New Orleans. 3. Flood control - Louisiana - New Orleans. 4. Structural failures - Louisiana - New Orleans. 5. Celotex Levee (La.) I. Torrey, Victor H. II. Wakeley, Lillian D. III. United States. Army. Corps of Engineers. Mississippi Valley Division. IV. U.S. Army Engineer Research and Development Center. V. Geotechnical Laboratory (U.S.) VI. Civil Works Research and Development Program (U.S.). Risk Analyses for Dam Safety. VII. Title. VIII. Title: Geological and geotechnical aspects of the Celotex Levee failure, New Orleans, Louisiana. IX. Series: Technical report GL ; 99-11.

TA7 E8 no.GL-99-11 


\section{Contents}

Preface $\ldots \ldots \ldots \ldots \ldots \ldots \ldots \ldots \ldots \ldots \ldots \ldots \ldots \ldots \ldots$ vii

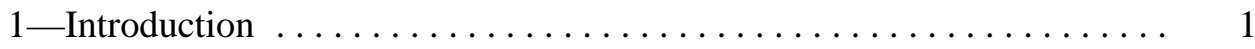

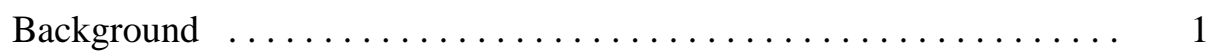

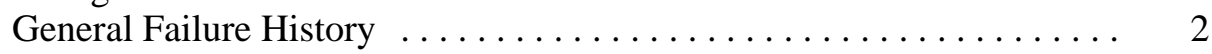

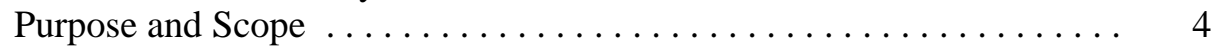

Study Area ............................... 4

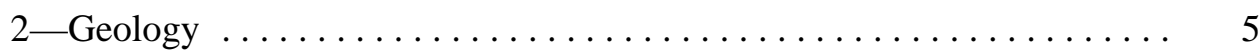

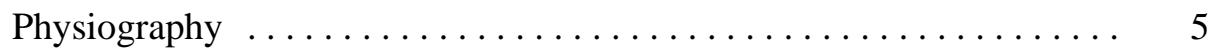

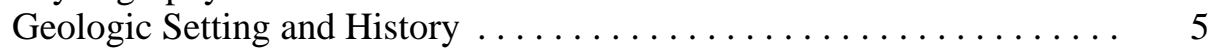

Geologic Structure ........................... 9

Geology and Environments of Deposition . . . . . . . . . . . . 10

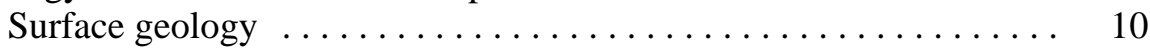

Subsurface geology ....................... 11

Geology of Selected Revetment Reaches . . . . . . . . . . . . . . . . 37

Celotex failure site and Greenville Bend revetment . . . . . . . . . 37

Carrollton Bend and Carrollton Bend revetment . . . . . . . . . 37

Gretna Bend and Gouldsboro revetments ............. 37

Algiers Point revetment ................... 38

3-Historic Mississippi River Migration . . . . . . . . . . . . . . . . 39

Bank Migration . . . . . . . . . . . . . . . . . . . . . . 39

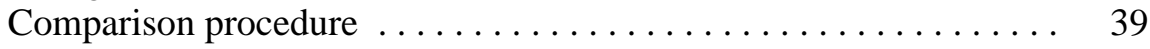

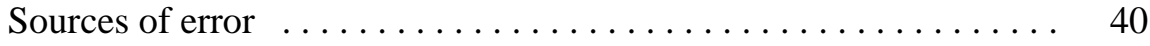

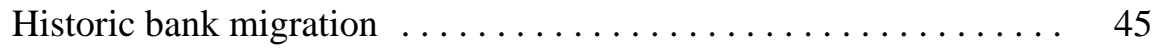

Scour Pool Migration . . . . . . . . . . . . . . . . . . . . . . 49

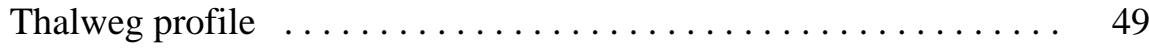

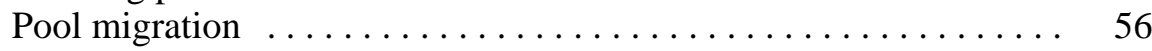

4 -Mississippi River Channel Morphology $\ldots \ldots \ldots \ldots \ldots \ldots$

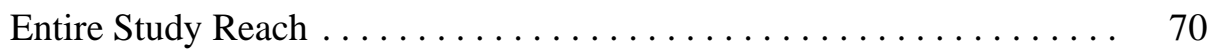

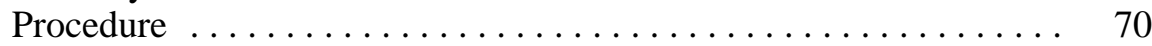

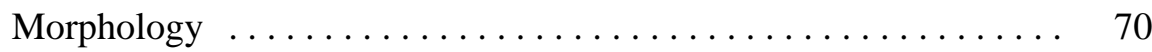

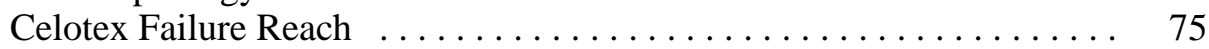

Procedure and profile locations $\ldots \ldots \ldots \ldots \ldots \ldots$

Discussion .......................... 85 
5-The Celotex Levee Failure . . . . . . . . . . . . . . . . . . 87

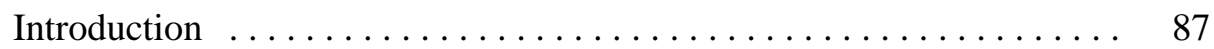

Failure History and Repair Chronology . . . . . . . . . . . . 87

Dimensions and General Character of the Celotex Failure . . . . . . . . 90

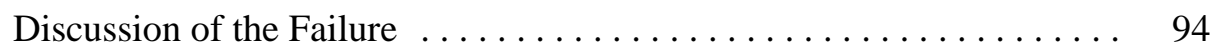

Historic Ramifications of the Celotex Failure . . . . . . . . . . . . . 105

Failure Mechanism .......................... 106

6-Conclusions and Recommendations _.................. 116

References ............................. 118

Appendix A: Environments of Deposition $\ldots \ldots \ldots \ldots \ldots \ldots \ldots$ A1

SF 298

\section{List of Figures}

Figure 1. Map of study area showing location of Celotex levee failure

failure ....................... 3

Figure 2. Holocene delta and distributary systems $\ldots \ldots \ldots \ldots \ldots$

Figure 3. General chronology of Mississippi River delta and distributary systems $\ldots \ldots \ldots \ldots \ldots \ldots \ldots \ldots \ldots$

Figure 4. Geologic map of the study area showing boring and cross section locations $\ldots \ldots \ldots \ldots \ldots \ldots \ldots \ldots \ldots \ldots \ldots \ldots \ldots$

Figure 5a. Geologic cross section $A-A^{\prime} \ldots \ldots \ldots \ldots \ldots \ldots \ldots$

Figure 5b. Geologic cross section A' $-A " \ldots \ldots \ldots \ldots \ldots \ldots \ldots$

Figure 5c. Geologic cross section $\mathrm{B}-\mathrm{B}, \ldots \ldots \ldots \ldots \ldots \ldots \ldots$

Figure 5d. Geologic cross section B' - B" ................. 19

Figure 5e. Geologic cross section $\mathrm{C}-\mathrm{C}$ ' .............. 21

Figure 5f. Geologic cross section $C^{\prime}-C^{\prime}{ }^{\prime} \ldots \ldots \ldots \ldots \ldots \ldots \ldots 23$

Figure 5g. Geologic cross section D - D' ................. 25

Figure 5h. Geologic cross section E - E' ............... 27

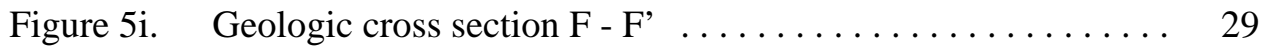

Figure $5 \mathrm{j} . \quad$ Geologic cross section $\mathrm{G}-\mathrm{G}^{\prime} \ldots \ldots \ldots \ldots \ldots \ldots \ldots \ldots \ldots$

Figure $5 \mathrm{k} . \quad$ Geologic cross section $\mathrm{H}-\mathrm{H}^{\prime} \ldots \ldots \ldots \ldots \ldots \ldots \ldots$

Figure 5l. Legend for the geologic sections of Figures 5a through 5k _ . 35

Figure 6. Generalized contour map of the Pleistocene surface ..... 36

Figure 7a. Bank migration comparisons between 1937 and $1984 \ldots \ldots .41$

Figure 7b. Bank migration comparisons between 1894 and $1984 \ldots \ldots .43$ 
Figure 8a. Bank migration changes for left bank between 1894 and 1984

Figure 8b. Bank migration changes for right bank between 1894 and

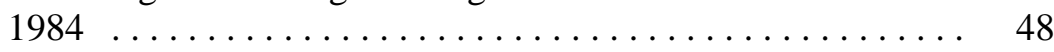

Figure 9a. Thalweg profiles for entire study reach $\ldots \ldots \ldots \ldots \ldots$

Figure 9b. Thalweg profiles at Carrollton Bend $\ldots \ldots \ldots \ldots \ldots \ldots$

Figure 9c. Thalweg profiles at Greenville Bend ........... 52

Figure 9d. Thalweg profiles at Gretna Bend ............. 53

Figure 9e. Thalweg profiles at Gouldsboro Bend ........... 54

Figure 9f. Thalweg profiles at Algiers Point ............... 55

Figure 10a. Scour pool comparisons for the $-100-\mathrm{ft}(-30.5-\mathrm{m})$ contour from river mile 111.9 to $101.8 \ldots \ldots \ldots \ldots \ldots \ldots \ldots$

Figure 10b. Scour pool comparisons for the $-100-\mathrm{ft}(-30.5-\mathrm{m})$ contour from river mile 103.8 to $95.0 \ldots \ldots \ldots \ldots \ldots \ldots \ldots$

Figure 10c. Scour pool comparisons for the $-100-\mathrm{ft}(-30.5-\mathrm{m})$ contour from river mile 97.0 to $88.6 \ldots \ldots \ldots \ldots \ldots \ldots \ldots \ldots$

Figure 11a. Scour pool comparisons for the $-150-\mathrm{ft}(-45.7-\mathrm{m})$ contour from river mile 111.9 to $101.8 \ldots \ldots \ldots \ldots \ldots \ldots \ldots 63$

Figure 11b. Scour pool comparisons for the $-150-\mathrm{ft}(-45.7-\mathrm{m})$ contour from river mile 103.8 to $95.0 \ldots \ldots \ldots \ldots \ldots \ldots \ldots \ldots$

Figure 11c. Scour pool comparisons for the $-150-\mathrm{ft}(-45.7-\mathrm{m})$ contour from river mile 97.0 to $88.6 \ldots \ldots \ldots \ldots \ldots \ldots \ldots$

Figure 12. Frequency histograms of W:D ratios for the 1894 and 1984 hydrographic surveys from river mile 91 to 106 (146.5 to $170.6 \mathrm{~km})$

Figure 13a. Locations of $\mathrm{W}: \mathrm{D}$ ratios for Carrollton Bend at 1 and 2 standard deviations below the mean value $\ldots \ldots \ldots \ldots 72$

Figure 13b. Locations of W:D ratios for Greenville Bend at 1 and 2 standard deviations below the mean value $\ldots \ldots \ldots \ldots$.

Figure 13c. Locations of W:D ratios for Gouldsboro Bend and Algiers Point at 1 and 2 standard deviations below the mean

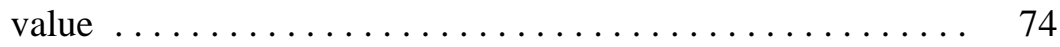

Figure 14a. Map showing locations of river profiles $\ldots \ldots \ldots \ldots \ldots$

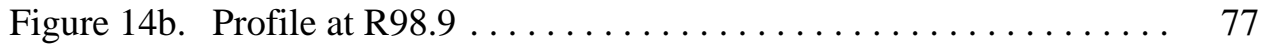

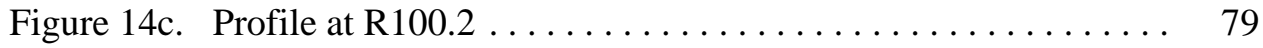

Figure $14 \mathrm{~d}$. Profile at $\mathrm{R} 100.3 \ldots \ldots \ldots \ldots \ldots \ldots \ldots \ldots \ldots \ldots \ldots$

Figure $14 \mathrm{e}$. Profile at $\mathrm{R} 100.6 \ldots \ldots \ldots \ldots \ldots \ldots \ldots \ldots \ldots \ldots \ldots$ 
Figure 15. Detailed location map of the Celotex batture and levee failure showing general outline of failure and 1973

hydrographic survey data $\ldots \ldots \ldots \ldots \ldots \ldots \ldots$

Figure 16. Aerial photo showing location of the Celotex failure . . . . . 89

Figure 17. Batture and levee restoration diagram of the Celotex

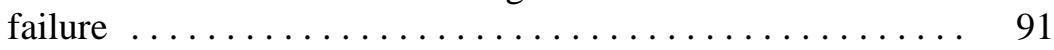

Figure 18. Topographic map of the Celotex batture and levee failure based on land survey, fathometer, and boring data ...... 93

Figure 19. Cross sections of the Celotex failure showing boring and profile data from selected time periods . . . . . . . . . 95

Figure 20. Computer image of the Celotex failure viewed from a position upstream; view is to the south $\ldots \ldots \ldots \ldots \ldots . . \ldots 7$

Figure 21. Computer image of the Celotex failure viewed from a position downstream; view is to the west . . . . . . . . 98

Figure 22. Soil profile along the bank reach containing the Celotex

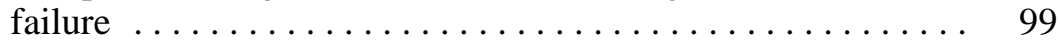

Figure 23. Hydrograph from the Carrollton gage during the period of the Celotex failure . . . . . . . . . . . . . . . 103

Figure 24. Side-scan sonar image of the Celotex failure reach . . . . . . 104

Figure 25. Historic bank lines for the Greenville revetment reach . . . . 107

Figure 26. General mechanism leading to bank failures where the river thalweg is in substratum sands . . . . . . . . . . . . . . 109

Figure 27. Sequential stages of retrogressive failure in dilatant sands . . 110

Figure A1. Topography of the buried Pine Island beach trend . . . . . . . A11 


\section{Preface}

The investigation reported here was initially authorized by the U.S. Army Engineer Division, Lower Mississippi Valley (CELMV), and represents a continuation of research by CELMV and the U.S. Army Engineer Research and Development Center (ERDC), Waterways Experiment Station (WES),

Vicksburg, MS, in evaluating potentially unstable riverbank sites. The principal investigator at WES who conducted this study was Dr. Victor H. Torrey III, Geotechnical Laboratory (GL). Dr. William F. Marcuson III is Director, GL.

This report was prepared at WES by Mr. J. B. Dunbar, Engineering Geology Branch, Dr. Torrey, Earthquake Engineering and Geophysics Branch, and Dr. L. D. Wakeley, Earthquake Engineering and Geosciences Division, GL. In addition, Mr. Jay L. Joseph, U.S. Army Engineer District, New Orleans, provided detailed information about the 1985 Celotex flow slides that was the key to the preparation of this report. The report was revised and completed as part of the work unit on Embankment Breach Analysis of the Civil Works R\&D Program on Risk Analysis for Dam Safety.

At the time of publication of this report, Dr. Lewis E. Link was Acting Director of ERDC, and COL Robin R. Cababa, EN, was Commander.

The contents of this report are not to be used for advertising, publication, or promotional purposes. Citation of trade names does not constitute an official endorsement or approval of the use of such commercial products. 


\section{Introduction}

\section{Background}

The U.S. Army Corps of Engineers (USACE), Lower Mississippi Valley Division (LMVD) and the U.S. Army Engineer Research and Development Center (ERDC), Waterways Experiment Station (WES), have conducted extensive research to understand the mechanism of retrogressive bank failures along the Mississippi River below Baton Rouge, LA. Understanding the failure mechanism is the key to developing preventive measures against retrogressive bank failures in sand deposits which pose a threat to levee stability. Presently, locations susceptible to these failures are identified by periodic hydrographic surveys, by empirical analyses of boring and geologic data, and by determination of engineering properties relevant to river bank stability.

Bank stabilization has been a major challenge for the LMVD since the formation of the Mississippi River Commission (MRC). As part of the various stabilization efforts conducted during the past century, many investigations were undertaken to determine the causes of failures and to explore methods to prevent them. Torrey, Dunbar, and Peterson (1988) reviewed the results and achievements of earlier studies and proposed a mechanism to explain the retrogressive failure process in sand deposits below Baton Rouge. Their report was the first of several reports that specifically defined and characterized the retrogressive failure mechanism. Their study examined the engineering geology and failure mechanisms responsible for two previous failures at Montz (river mile 130) and Lucy (river mile 135), Louisiana.

In the second report in this series, Torrey (1988) examined other failures, including the Celotex failure, to provide additional empirical evidence for the proposed failure mechanism. Additionally, that report examined historic bank migration along the Mississippi River below Baton Rouge during the period 1879 to 1975 to show specific trends which may negatively impact levee safety.

The third report (Dunbar and Torrey 1991) was an engineering-geology investigation of the Marchand levee failure of 1983 and included a 23-mile (37-km) reach of river encompassing the failure. That study indicated that the Marchand failure was different from previous failures studied because it occurred in thick backswamp deposits rather than sandy point bar deposits. However, the regression mechanism identified at the other failure sites was applicable to this failure as well. Scour had apparently induced the retrogressive mechanism in the underlying substratum sands and undermined the upper bank. 
Furthermore, the study revealed that the Marchand reach had experienced chronic bank loss problems, including two previous setbacks within the past 80 years.

During 1999, the USACE initiated a new research program, Risk Analysis for Dam Safety. Research on embankment breach analysis is part of this renewed USACE commitment to improve the safety and reliability of embankment dams and levees. At the USACE Geotechnical and Materials Conference in August 1999, several papers were presented about performance problems, including some failures of levees and embankments. A theme common to many of the embankment cases described during the conference was the specific features of the geologic setting contributed to breaching or failure. Further, in most cases the potential for geologic features to contribute to failure was not understood at the time the structure was designed and constructed. There is much to learn about predicting embankment failures by studying case histories and the geologic settings of failures. Thus, this report contributes to the body of knowledge available for current and future development of risk prediction tools and retrofitting of embankments to improve public safety.

This report is a case history of the Celotex failure. The Celotex bank failure has been traditionally referred to as a "flow failure" and has been empirically associated with point bar deposits as have most such failures of record. Many point bar deposits occurring below Baton Rouge are characterized by a thick sandy substratum beneath a relatively thin cohesive overburden or topstratum. As was the case in the earlier Marchand failure, the Celotex failure added its own new twist to the general flow slide problem because it occurred during the low-water period of the year. It was also of a variant nature compared with earlier failures because it was in point bar deposits associated with an abandoned distributary course from an ancient Mississippi River delta complex. This report will define and evaluate the engineering geology and the interpreted failure mechanism.

\section{General Failure History}

On 30 July 1985, a levee failure occurred on the west (right descending) bank of the Mississippi River at 100.25 river miles (161.34 km) Above Head of Passes $^{1}$ (AHP) in the Jefferson Levee District (Figure 1). The failure location was near the community of Marrero, LA, which is part of the greater New Orleans metropolitan area. More specifically, because it occurred in front of the old Celotex Corporation industrial site, it was referred to as the Celotex failure. Details concerning the chronology of events and the repair method are given in Chapter 5.

1 River mileage pertinent to this report is measured in the upstream direction from a point designated as zero where the river channel divides into several smaller channels called "Head of Passes" and then flows out into the Gulf of Mexico through its true delta. New Orleans, LA, is at about 100.0 miles $(160.9 \mathrm{~km})$ AHP and Baton Rouge, LA, is at about 234.0 miles $(376.6 \mathrm{~km})$ AHP. Henceforth in this report, references to river mileage will refer to miles without replication of the AHP designator. 


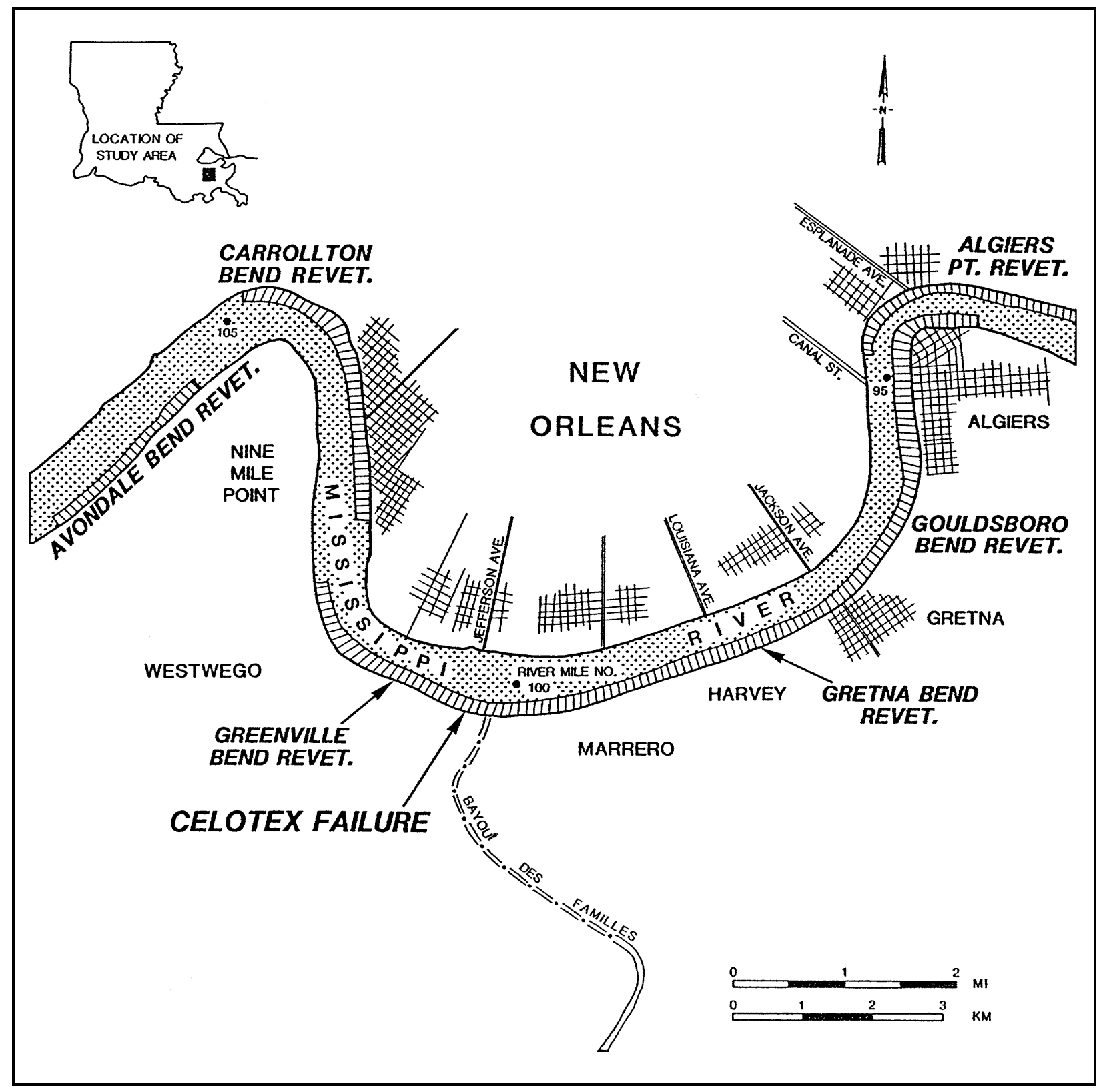

Figure 1. Map of study area showing location of the Celotex levee failure

Emergency repair operations were undertaken by the U.S. Army Engineer District, New Orleans (LMN) immediately after the failure. An old asbestos waste pit was discovered landward of the original levee alignment. LMN decided that an embankment setback was not the most cost-efficient restoration of the levee due to the environmental hazards which would have to be addressed. Instead, a unique repair approach was employed wherein the levee was rebuilt in its existing alignment, after the riverbank profile was restored by filling the failure scarp with shell. Repair operations were completed on 28 November 1985. 
The failure involved approximately $200 \mathrm{ft}(61 \mathrm{~m})$ of the mainline levee embankment. At its widest point, which was approximately $200 \mathrm{ft}(61 \mathrm{~m})$ riverside of the center line of the levee crown, the failure was about $600 \mathrm{ft}$ $(183 \mathrm{~m})$ wide parallel to the river and extended out into the Mississippi River to approximately the $-80 \mathrm{ft}$ (-24 m) National Geodetic Vertical Datum (NGVD) contour. Torrey (1988) estimates that the total volume of material displaced by the failure was approximately $300,000 \mathrm{cu}$ yd $(229,000 \mathrm{cu} \mathrm{m})$.

\section{Purpose and Scope}

The purpose of this study was to determine the cause(s) for the Celotex levee failure. This report will identify and evaluate important characteristics about the engineering geology of the Celotex levee failure. Major objectives of this study are (a) to determine the surface and subsurface geology within the failure reach, (b) define the general Holocene chronology and the historic movement of the river through the study area, (c) examine the general characteristics of the channel geometry in the failure reach, and (d) reconstruct the mechanism responsible for the Celotex levee failure. A further purpose for publishing this report is to document a critically important embankment failure, thereby contributing to prediction of other potential embankment failures.

\section{Study Area}

To better understand changes that have occurred in the failure reach, the study area was defined to include the river reach between miles 91.0 to 106.0 $(146.45$ to $170.59 \mathrm{~km})$ as shown in Figure 1. Within this reach are the Avondale (right bank, river mile 106.0 to 105.0 (170.58 to $168.98 \mathrm{~km}$ )), Carrollton Bend (left bank, river mile 105.0 to 102.0 (168.98 to $164.15 \mathrm{~km}$ )), Greenville Bend (right bank, river mile 102.0 to 98.3 (164.15 to $158.19 \mathrm{~km}$ )), Gretna Bend (right bank, river mile 98.3 to 96.5 (158.19 to $155.3 \mathrm{~km}$ )), Gouldsboro Bend (right bank, river mile 96.5 to 95.5 (155.3 to $153.69 \mathrm{~km}$ )), Algiers Point (left bank, river mile 95.5 to 93.7 (153.69 to $150.79 \mathrm{~km}$ )) and Third District Reach (left bank, river mile 94.9 to 91.0 (152.72 to $146.45 \mathrm{~km}$ )) revetments (Figure 1). The study area, as shown in Figure 1, is located in the northern half of the New Orleans 15-minute U.S. Geological Survey (USGS) topographic quadrangle. The study area includes portions of Orleans and Jefferson Parishes, Louisiana. 


\section{Geology}

\section{Physiography}

The study area is located in the southern portion of the lower Mississippi Valley and is a part of the Mississippi River's deltaic plain. Broad natural levees associated with the Mississippi River and Bayou des Familles, a prehistoric distributary channel, are the most prominent physiographic features in this area. Surface topography is generally of low relief with surface elevations ranging from approximately $25 \mathrm{ft}(7.6 \mathrm{~m}) \mathrm{NGVD}$ along the levee crests to sea level throughout much of the study area. Over a significant part of the New Orleans Metropolitan area the surface elevation is at or below sea level.

In the New Orleans area, the meander pattern of the Mississippi River is distinctive, making four nearly right angle turns which have changed very little during the past 100 years (Figure 1). The width of the Mississippi River within the study area (river mile 91.0 to 106.0 (146.45 to $170.59 \mathrm{~km})$ ) ranges from $1,750$ to $2,700 \mathrm{ft}$ (533 to $823 \mathrm{~m})$. The river thalweg elevations through this reach range from $-70 \mathrm{ft}(-21 \mathrm{~m})$ to about $-190 \mathrm{ft}(-58 \mathrm{~m})$ NGVD. The top of the bank elevation through the study reach averages about $10 \mathrm{ft}(3 \mathrm{~m})$ NGVD. Channel bendways are characterized by deep "permanent" scour pools separated by shallower crossings. Revetment protection along the river corresponds to the deeper scour pools at Avondale, Carrollton, Greenville, Gretna, Gouldsboro, and Algiers (Figure 1).

\section{Geologic Setting and History}

The scope of this study permits a summary of the major events to explain the significance of the engineering geology in the study area. The general geologic chronology that has been defined for the Mississippi River's deltaic plain is based upon thousands of engineering borings drilled during the past 50 years, hundreds of radiometric age determinations of organic deltaic sediments, and numerous geologic studies conducted in this region (Fisk 1944; Kolb and Van Lopik 1958a and 1958b; Kolb 1962; Kolb, Smith, and Silva 1975; Autin et al. 1991; Frazier 1967; Saucier 1969 and 1974; May et al. 1984; Dunbar et al. 1994 and 1995; Smith, Dunbar, and Britsch 1986). Boring data identify a diverse surface and subsurface geology that is related to the different course shifts by the Mississippi River and associated deltaic advances during the Holocene (last 10,000 years). 
To better understand the geology of the area, it is first necessary to briefly review the geologic history of coastal Louisiana since the late Pleistocene (17,000 to 10,000 years ago). Approximately 17,000 years ago, glaciers covered much of North American and sea level was approximately $300 \mathrm{ft}(91 \mathrm{~m})$ below the present level (Kolb, Smith, and Silva 1975). The Gulf shoreline was much farther seaward than at its present location.

The ancestral Mississippi River and its tributaries below Baton Rouge, LA, were entrenched into the underlying Pleistocene surface and had developed a broad drainage basin, approximately 25 miles $(40 \mathrm{~km})$ wide, which extended southeasterly beneath the present deltaic plain (Kolb and Van Lopik 1958a). Geologic mapping (Kolb and Van Lopik 1958a and 1958b; May et al. 1984) indicates that the axis of the valley entrenchment occurs in the vicinity of Houma, LA, approximately 45 miles $(72 \mathrm{~km})$ southwest of New Orleans.

The underlying Pleistocene surface represents deposits from a much older Mississippi River deltaic plain sequence and associated nearshore environments. These sediments were deposited during the previous interglacial cycle (Sangamon interglacial period), approximately 125,000 to 70,000 years ago. Fisk (1944) collectively called these Pleistocene sediments the Prairie Formation. Sediments of the Prairie Formation outcrop at the surface just north of Lake Pontchartrain.

Sea level began rising approximately 17,000 years ago because of glacial melting and reached its present level between 4,000 and 6,000 years before the present. Rising sea level corresponds to a period of valley-wide aggrading of the ancestral alluvial valley by the existing fluvial systems. Melting glaciers released large quantities of sediment to the Pleistocene drainage system and filled the entrenched valley with coarse sediments (sand and gravel). A dense network of shallow and swiftly flowing braided stream courses formed within the ancestral alluvial valley because of overloading by the massive influx of glacial outwash. Along the length and width of the Lower Mississippi Valley, basal substratum sands are present in the subsurface which represent the relic braided stream or outwash plain sediments from glacial melting (Fisk 1944; Kolb et al. 1968; Krinitzsky and Smith 1969; Saucier 1964 and 1967; Smith and Russ 1974). The change in deposition from a braided system to a meandering Mississippi River system occurred approximately 12,000 years before the present (Saucier 1969; and Krinitzsky and Smith 1969).

Advent of the modern sea level began creation of the modern deltaic plain and led to the present land surface. Present day coastal Louisiana is the product of numerous, but generally short lived, seaward prograding delta systems. These deltas are subsequently reworked by coastal transgressive processes and modified. Five major deltaic systems have been built seaward during the past 6,000 years as shown by Figure 2 (after Frazier 1967). Each delta system consists of several major distributary channels and numerous individual delta lobes (Figure 3). The relative ages of these delta systems are generally well established by radiocarbon dating techniques. Limits of the different delta systems and the chronology of the major distributary channels associated with each system are summarized in Figures 2 and 3 (after Frazier 1967). 


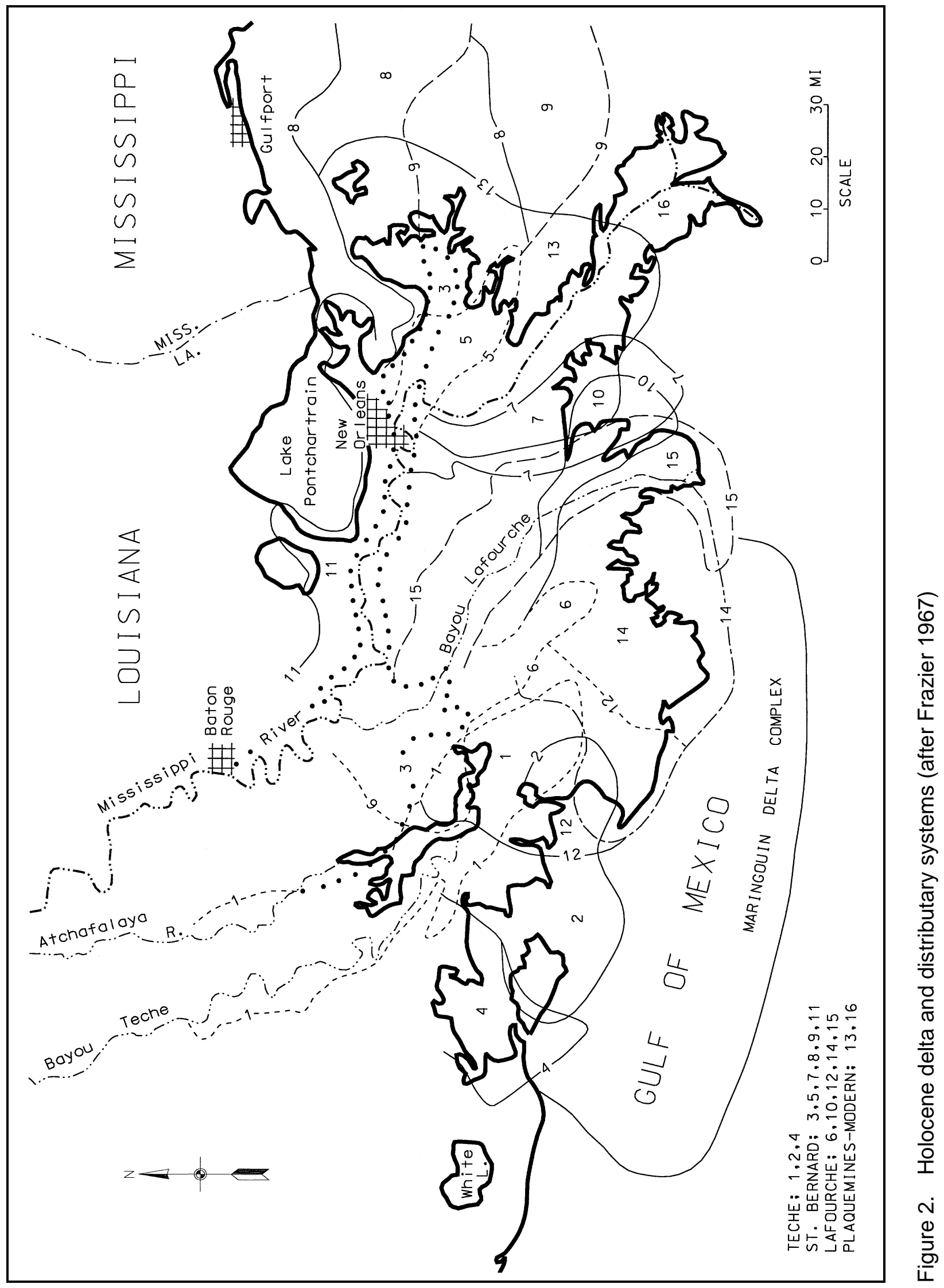




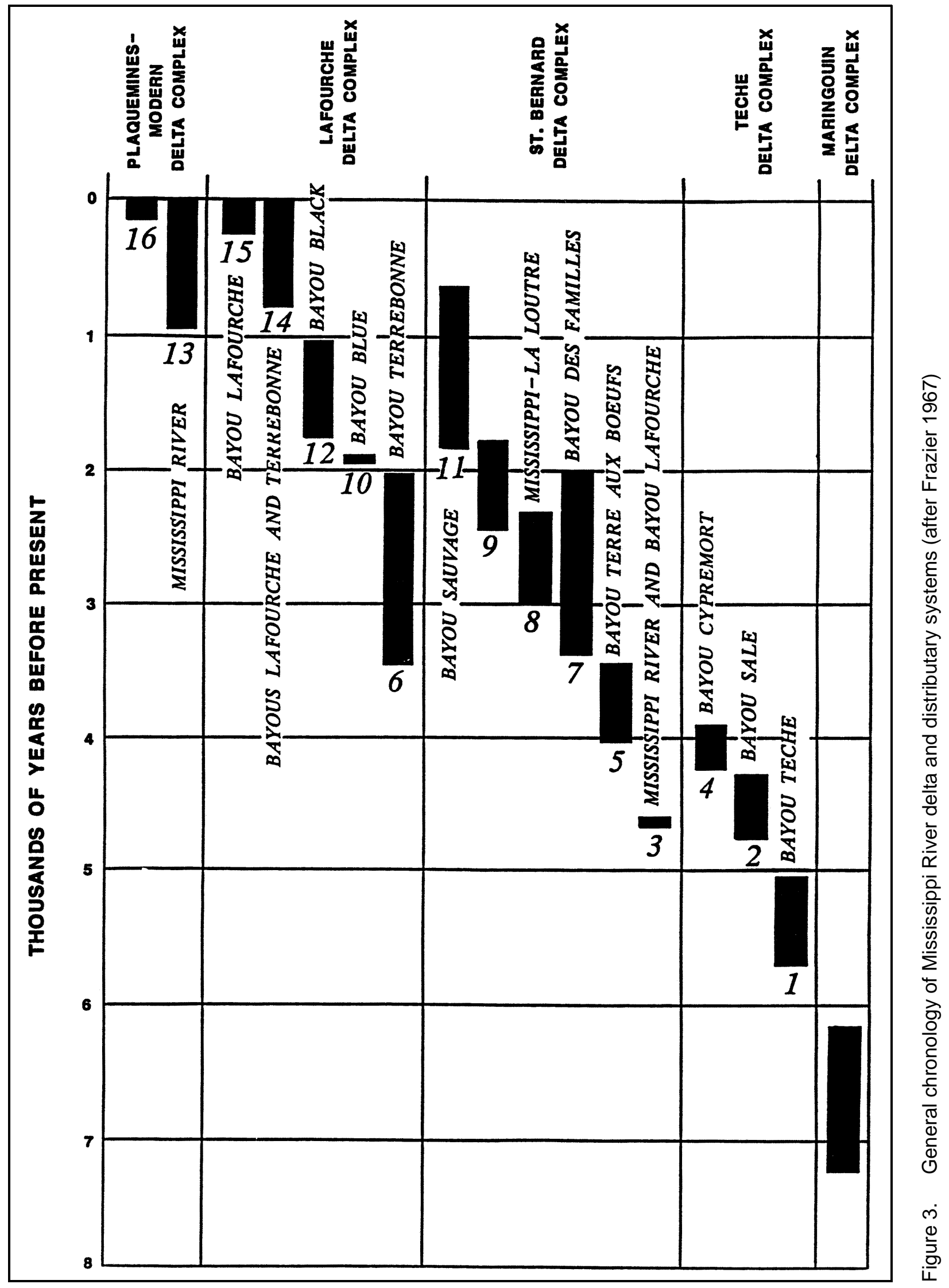


The first advance of a major delta system into the New Orleans area occurred with the St. Bernard system. The present course of the Mississippi River through the New Orleans area was established during the active St. Bernard delta. Partial Mississippi River flow continued to pass through the New Orleans reach following abandonment of the St. Bernard system for the Lafourche delta complex. During the active Lafourche system, the Mississippi River flowed southward at Donaldsonville, through Bayou Lafourche, and to the Gulf of Mexico. After abandonment of the Lafourche system approximately 500 years ago, nearly full Mississippi River flow returned to the present day course.

\section{Geologic Structure}

The study area is part of the seaward thickening wedge of Quaternary sediments which dip gently gulfward and fill the Gulf of Mexico geosyncline. Major structures within this sedimentary prism are piercement salt domes and growth faults. In the study area there are no buried salt domes. The vast majority of Louisiana's salt domes are located south and west of the New Orleans area (New Orleans Geological Society 1962 and 1983; and Halbouty 1967).

Faulting has been identified in the subsurface throughout the deltaic plain and in the Pleistocene deposits exposed at the surface north of Lake Pontchartrain (Wallace 1966; and Snead and McCulloh 1984). These faults are not tectonically active. Instead, they are related to sedimentary loading of the Gulf of Mexico basin. Faulting has been identified in the Pleistocene sediments beneath Lake Cataouatche (approximately 8 miles $(12.8 \mathrm{~km})$ southwest of New Orleans) and beneath Lake Pontchartrain (Wallace 1966; and Kolb, Smith, and Silva 1975). Fisk (1944) identified several normal faults in the buried Pleistocene sediments beneath New Orleans. He interpreted these faults based on the orientation of stream courses, lake shores, and the Mississippi River. The presence of these faults based solely on this type of evidence is speculative without more detailed stratigraphic evidence to support their existence. Nontectonic geomorphic and stratigraphic processes can produce these types of linear features without faulting as the underlying mechanism. A detailed engineering study of Pleistocene sediments in the New Orleans area by Kolb, Smith, and Silva (1975) did not identify subsurface faults near the Celotex failure site or for the general New Orleans area. Their study identified only one fault in the New Orleans area (in Lake Pontchartrain) and was based on combined boring and geophysical (subbottom profiling) data.

No faults were identified during this investigation in the study area. Surface faults in Holocene sediments are difficult to detect, because unconsolidated sediments tend to warp rather than shear. Geologic mapping and boring data evaluated during the course of this study did not identify any surface or subsurface faulting in the study area. 


\section{Geology and Environments of Deposition}

\section{Surface geology}

The first objective of this investigation was to map and define the surface and subsurface geology of the study area. Definition of the geology was accomplished by examination and interpretation of historic aerial photography, subsurface data (engineering borings and electrical logs), different hydrographic survey periods, historic maps, and by review of the available geologic literature (Autin et al. 1991; Eustis Engineering Company 1984; Frazier 1967; Kemp 1967; Kolb 1962; Kolb and Van Lopik 1958a and 1958b; Kolb, Smith, and Silva 1975; Kolb and Saucier 1982; Miller 1983; Saucier 1963; Self and Davis 1983). A map of the surface geology for the study area is presented in Figure 4.

Environments of deposition mapped at the surface in Figure 4 include natural levee, point bar, inland swamp, fresh marsh, and several abandoned distributary channels. A complete description of the different environments of deposition present in the study area is contained in Appendix A. Natural levee deposits identified on the geologic map in Figure 4 are shown with the underlying environment of deposition. The surface geology consists primarily of Mississippi River natural levee and point bar deposits, several abandoned distributary channels, and their associated fluvial and deltaic deposits.

Formation of the study area is directly related to the past and present courses of the Mississippi River and its abandoned distributary channels. Abandoned distributary channels within the study area are associated with two major distributary systems, Bayou des Familles-Barataria and Bayou Sauvage-Metarie Bayou (Figure 4). Bayou Des Familles-Barataria is a major St. Bernard distributary channel or Mississippi River course which extends due south from the Mississippi River at the Celotex failure site to Barataria, LA. This distributary system was active from approximately 2,000 to 3,400 years before the present (Frazier 1967).

The second major distributary course mapped in the study area is Bayou Sauvage-Metarie Bayou. According to Frazier (1967), this course was active from about 800 to 1,800 years before the present (Figure 3). However, Saucier (1963) and Kolb and Van Lopik (1958a) indicate that this system may have been active even earlier. Radiocarbon dates from organic sediments beneath the natural levees of Metarie Bayou range from 2,300 to 2,600 years before the present and indicate that a marsh surface was developed within this area. Metarie Bayou intersects the Mississippi River at Kenner and extends eastward, branching into two segments north of Algiers Point. The northern branch extends northeast toward Chef Menteur, Louisiana, as Bayou Sauvage. The southern branch, labeled Unknown Bayou by Saucier (1963), intersects the Mississippi River at Algiers Point (Figures 1 and 4), follows the Mississippi River between Algiers Point and Gretna, and then extends due southeast where it intersects the Mississippi River at 12 Mile Point. 


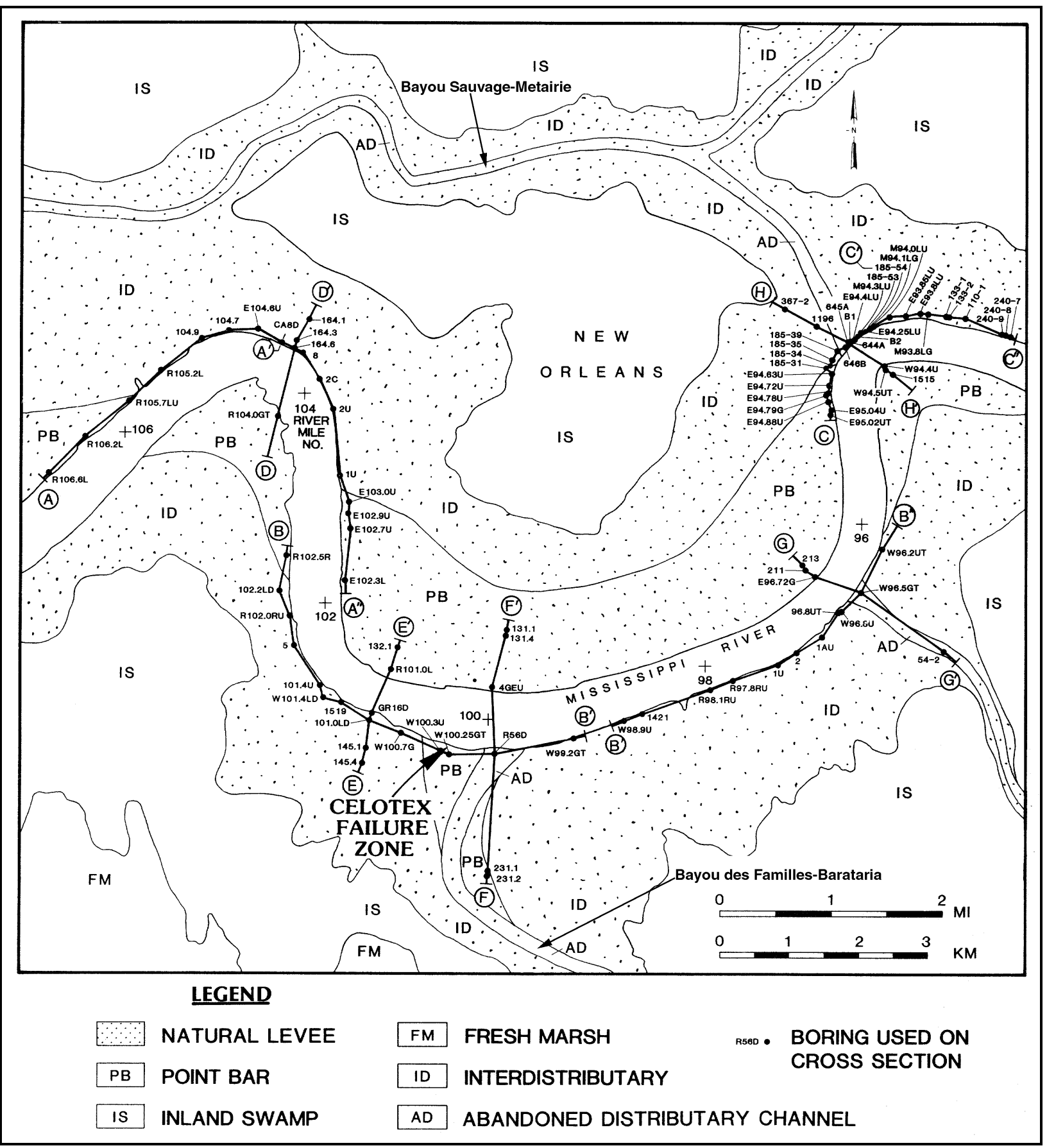

Figure 4. Geologic map of the study area showing boring and cross section locations

\section{Subsurface geology}

Eight geologic cross sections were constructed from borings collected and evaluated during this study. The locations of the cross sections are shown on the geologic map in Figure 4. Cross sections A through $\mathrm{H}$ are presented as Figures $5 \mathrm{a}$ through $5 \mathrm{k}$, respectively. The longer cross sections are presented as 
two separate sections or figures for illustration purposes. A legend of symbols and soil types identified on the sections is presented in Figure 51. Sections were constructed such that each revetment reach includes sections parallel and perpendicular to the river bank. Parallel sections were constructed for only the cutbank or concave side as this is the side for maximum erosion and potential bank instability. The majority of soil types shown on the geologic sections are classified according to the Unified Soil Classification System (USCS). Borings not using the USCS (e.g., borings from private engineering companies) are shown with their textural soil types identified. The geologic cross sections show the vertical and horizontal limits of the various environments of deposition adjacent to the river as well as the soil types that form these different environments. Depositional environments present in the subsurface include interdistributary, intradelta, and nearshore gulf. A general description of these environments is contained in Appendix A. For readers desiring further engineering soils data beyond what is presented in this report, a detailed summary of soil engineering properties for the various environments of deposition is presented by Kolb (1962) and Montgomery (1974).

Beneath the nearshore gulf sequence is the Pleistocene surface. The nearshore gulf sediments represent the deposits formed by the transgression of sea level onto the Pleistocene surface. These sediments were deposited under shallow-water conditions, before the advancement of the two major St. Bernard distributary systems into the study area. Establishment of the St. Bernard distributary systems into the study area produced the interdistributary sediments that were deposited into shallow-water, freshwater areas between the active distributary channels. Interdistributary sediments over time filled these shallow areas, and emergent vegetation in the form of fresh marsh began developing when interdistributary filling approached sea level. Closer to the active distributary systems, overbank deposition from the active distributary channels developed well drained natural levees and inland swamps.

A generalized contour map of the Pleistocene surface is presented in Figure 6 (Kolb, Smith, and Silva 1975). In general, the Pleistocene surface throughout the study area dips to the south and southwest at approximately $3 \mathrm{ft}$ per mile $(1 \mathrm{~m}$ per $1.6 \mathrm{~km})$. Surface elevations on this surface are variable due to erosion by the preexisting Pleistocene drainage system and later Holocene scouring by past and present courses of the Mississippi River and its distributaries. Elevations of the Pleistocene surface range from $-50 \mathrm{ft}(-15 \mathrm{~m})$ NGVD to greater than $-150 \mathrm{ft}(-46 \mathrm{~m})$ NGVD in the bendways of the present Mississippi River channel.

Pleistocene deposits are characterized by a significant increase in stiffness and shear strength as compared to the overlying Holocene sediments. Pleistocene soils are fairly resistant to erosion from fluvial scouring. Where these soils occur in the riverbank, they represent a "hard point" which restrains the river's migration and deepening. Pleistocene deposits in the bed and bank of the river have had a significant influence on the river's ability to meander through the study area. There has been very little migration of the channel during the past 100 years as determined from comparison of old hydrographic surveys in Chapter 3 of this report. 


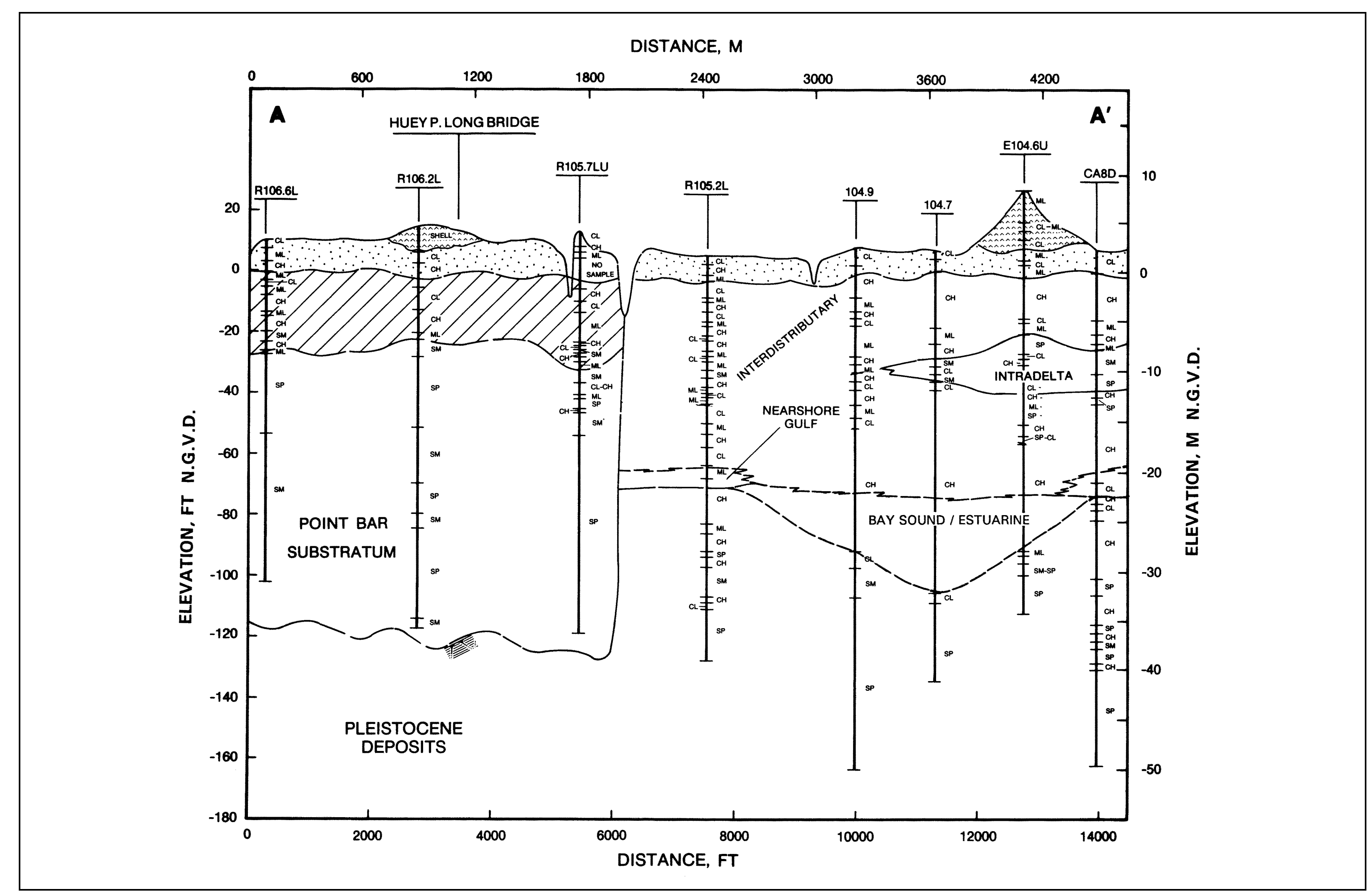

Figure 5a. Geologic cross section A-A' (see Figure 5 f for symbol legend) 


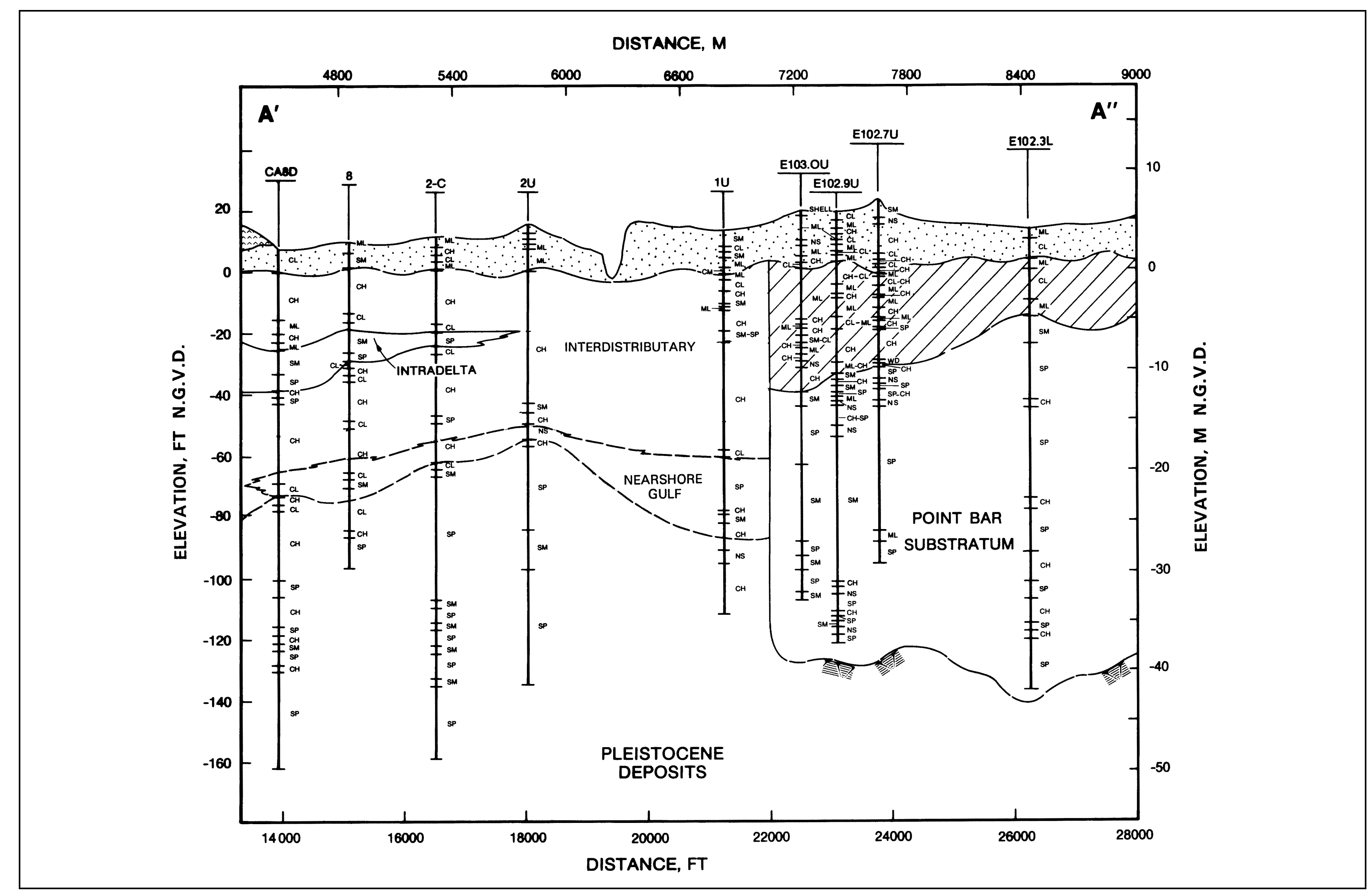

Figure 5b. Geologic cross section A'-A" (see Figure 51 for symbol legend) 


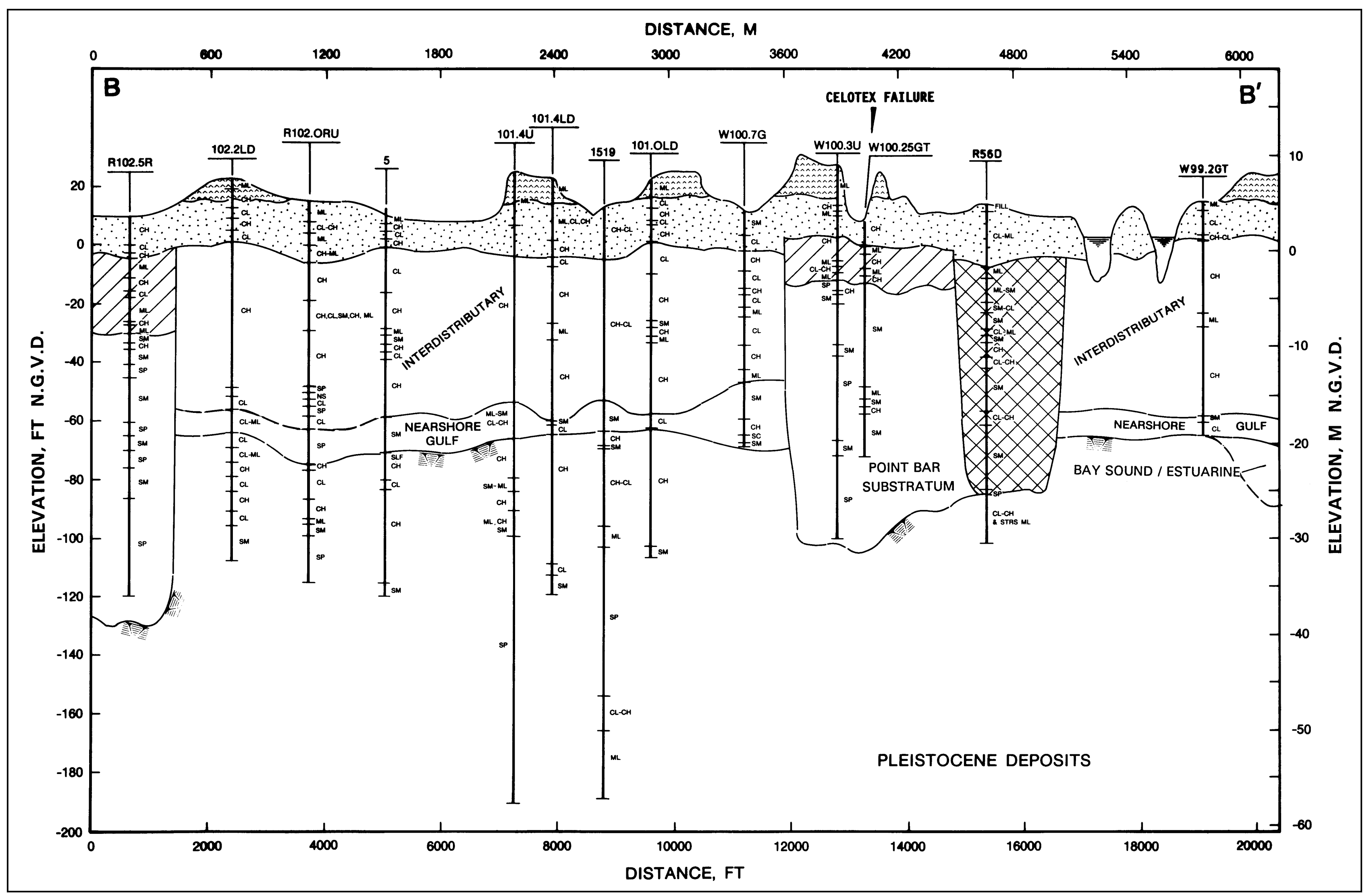

Figure 5c. Geologic cross section B-B' (see Figure 5 f for symbol legend) 


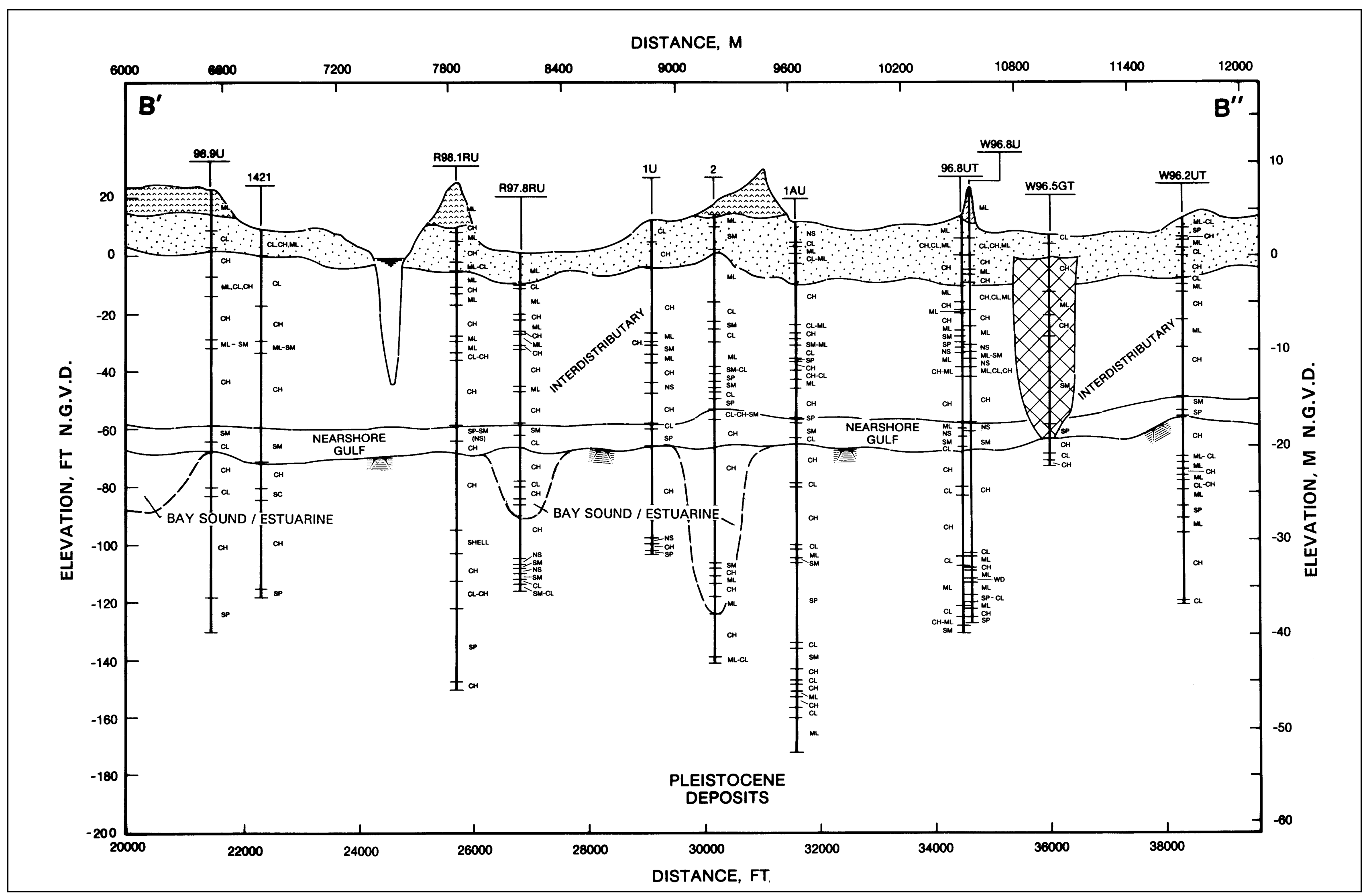

Figure 5d. Geologic cross section B'-B" (see Figure 51 for symbol legend) 


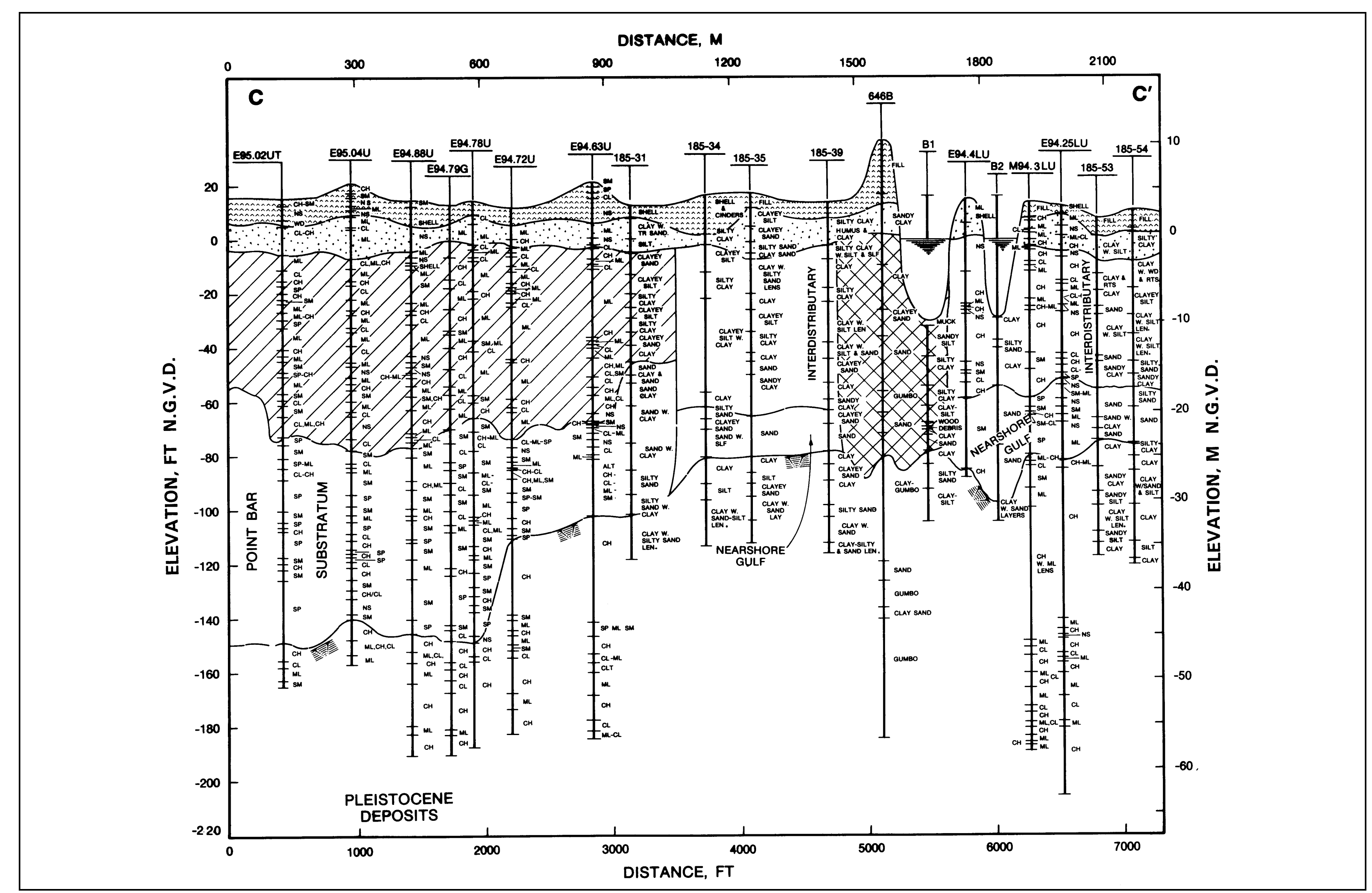

Figure 5e. Geologic cross section C-C' (see Figure 51 for symbol legend) 


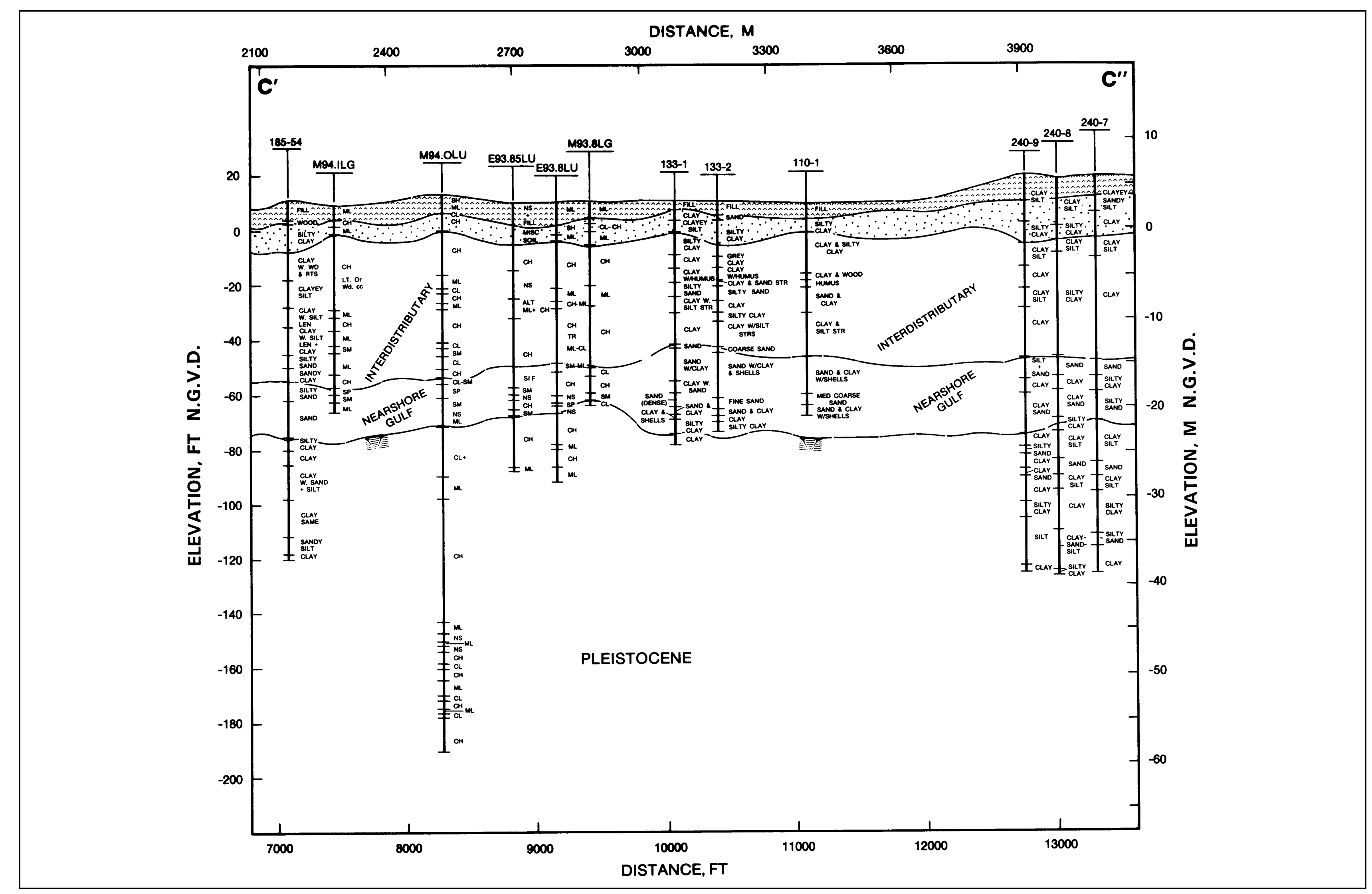

Figure 5f. Geologic cross section C'-C" (see Figure 51 for symbol legend) 


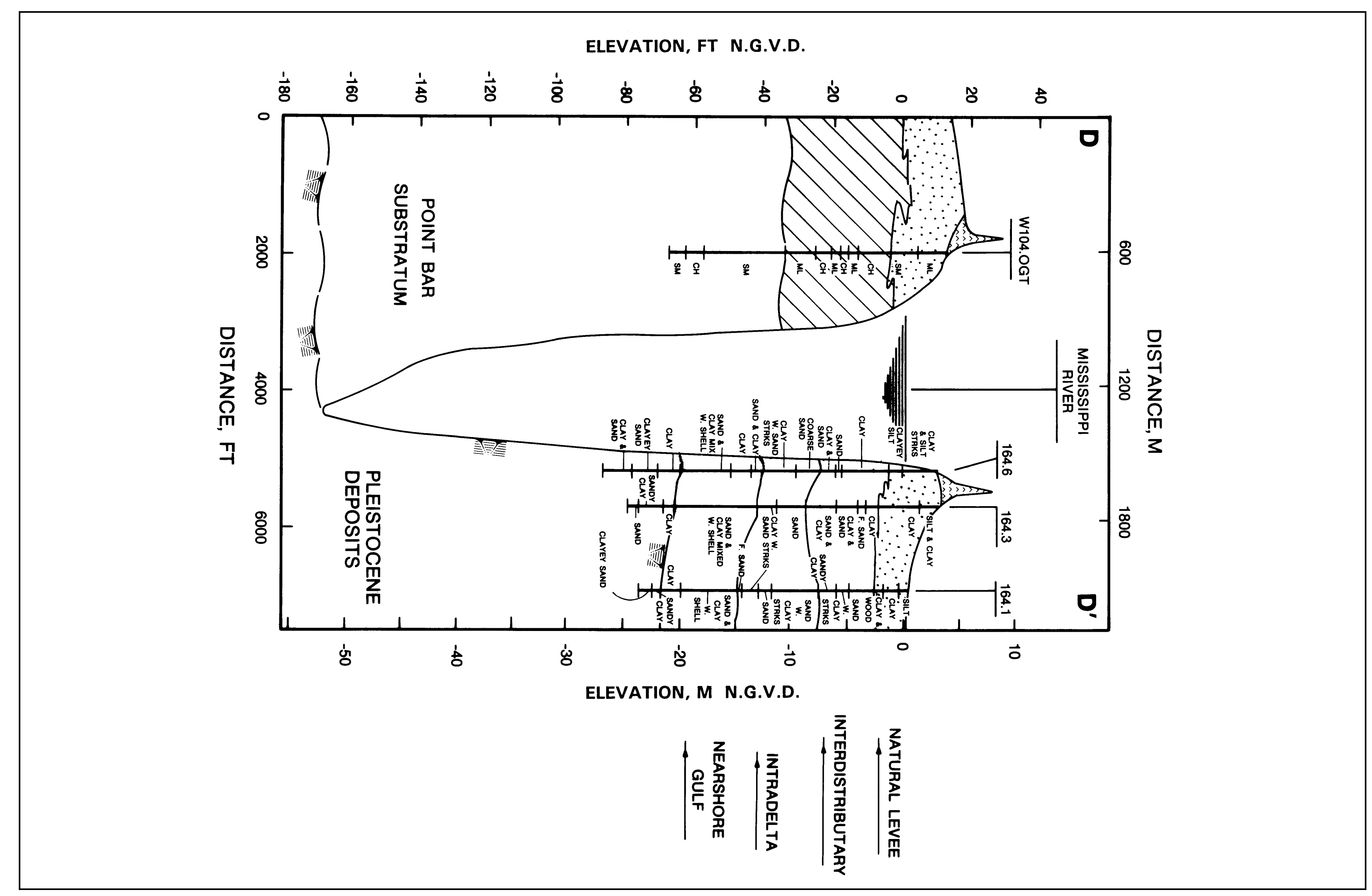

Figure 5g. Geologic cross section D-D' (see Figure 51 for symbol legend) 


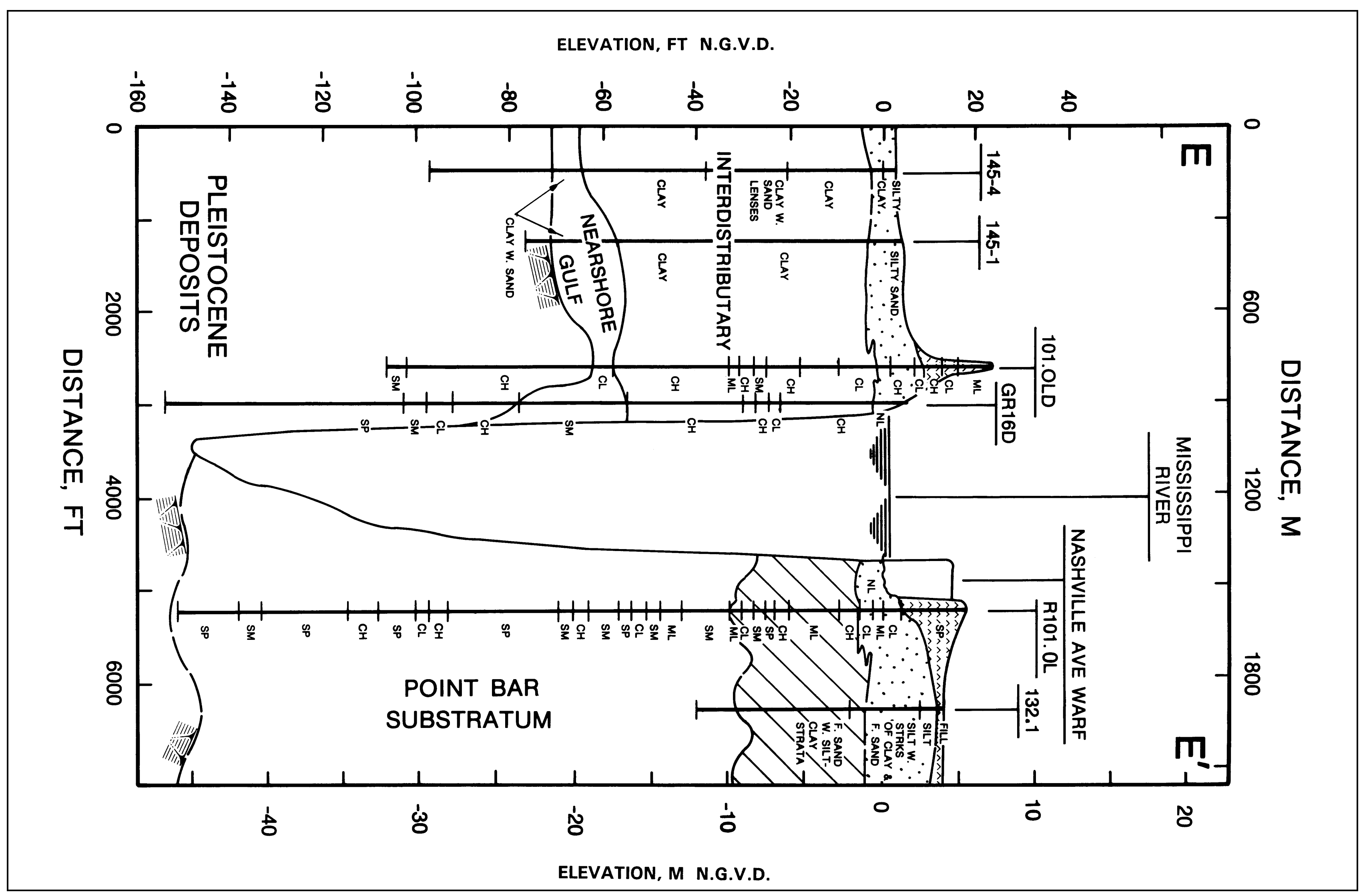

Figure 5h. Geologic cross section E-E' (see Figure 51 for symbol legend) 


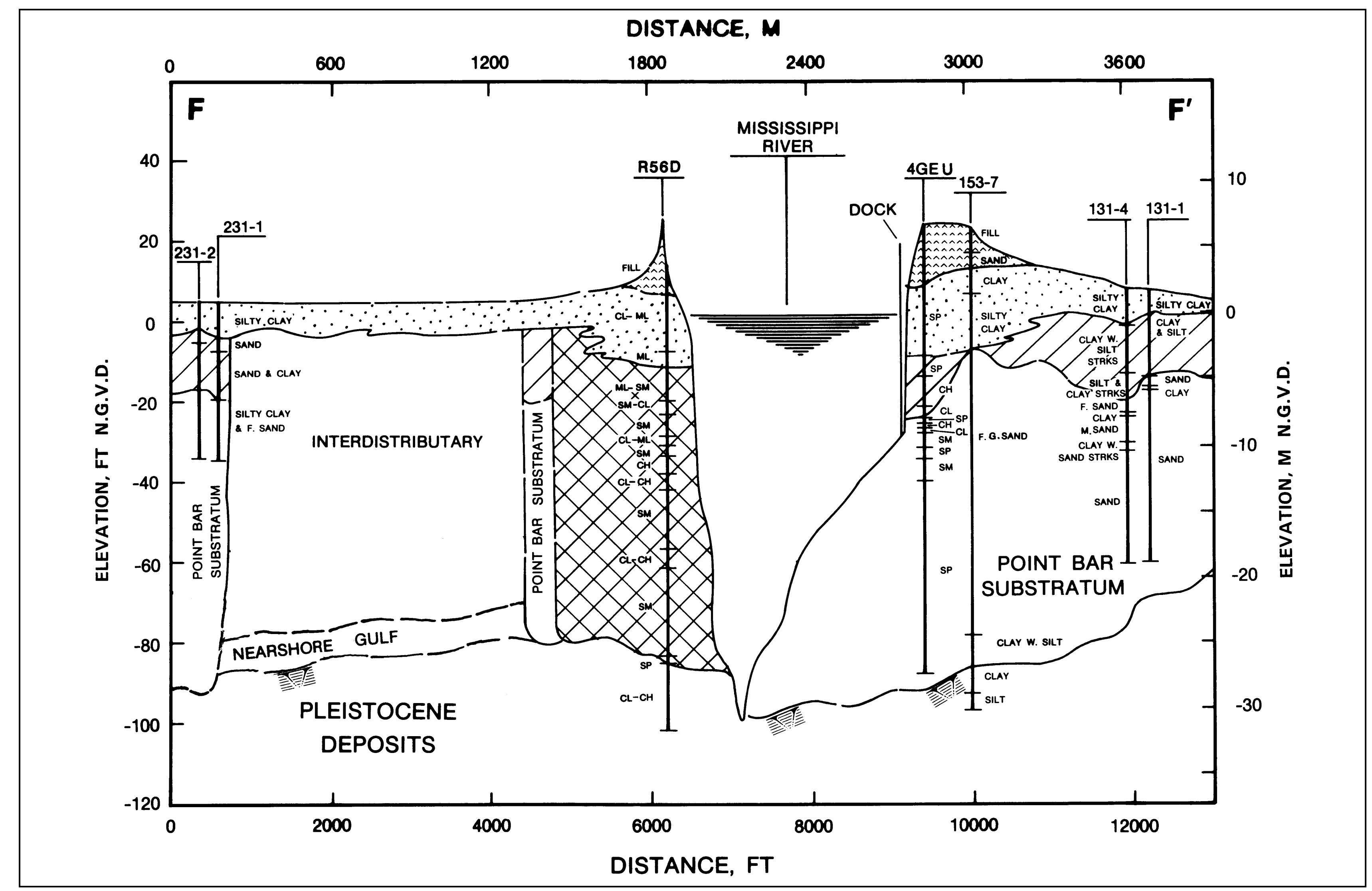

Figure 5i. Geologic cross section F-F' (see Figure 5 l for symbol legend) 


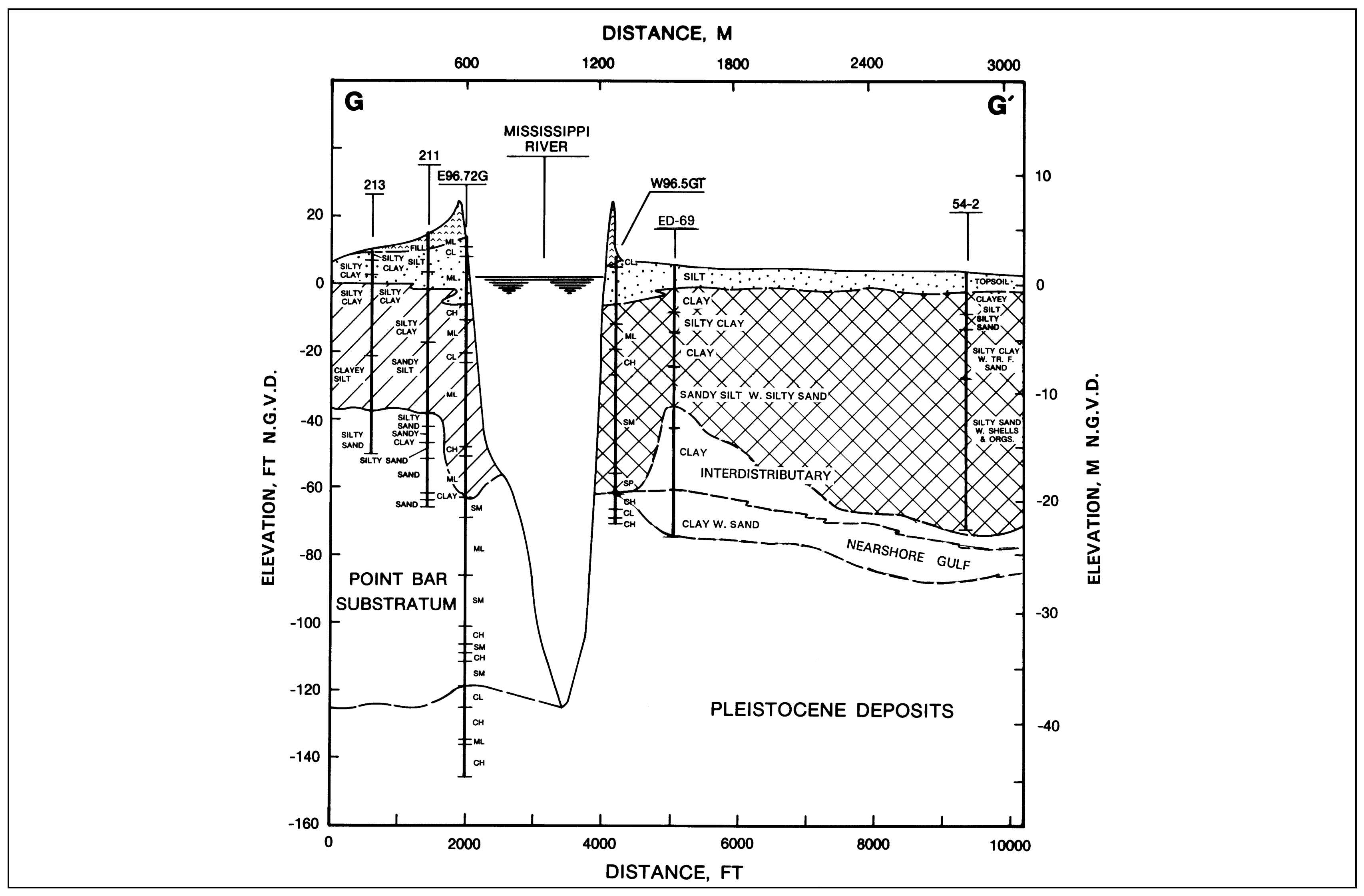

Figure 5j. Geologic cross section G-G' (see Figure Fl for symbol legend)

Chapter 2 Geology

31 


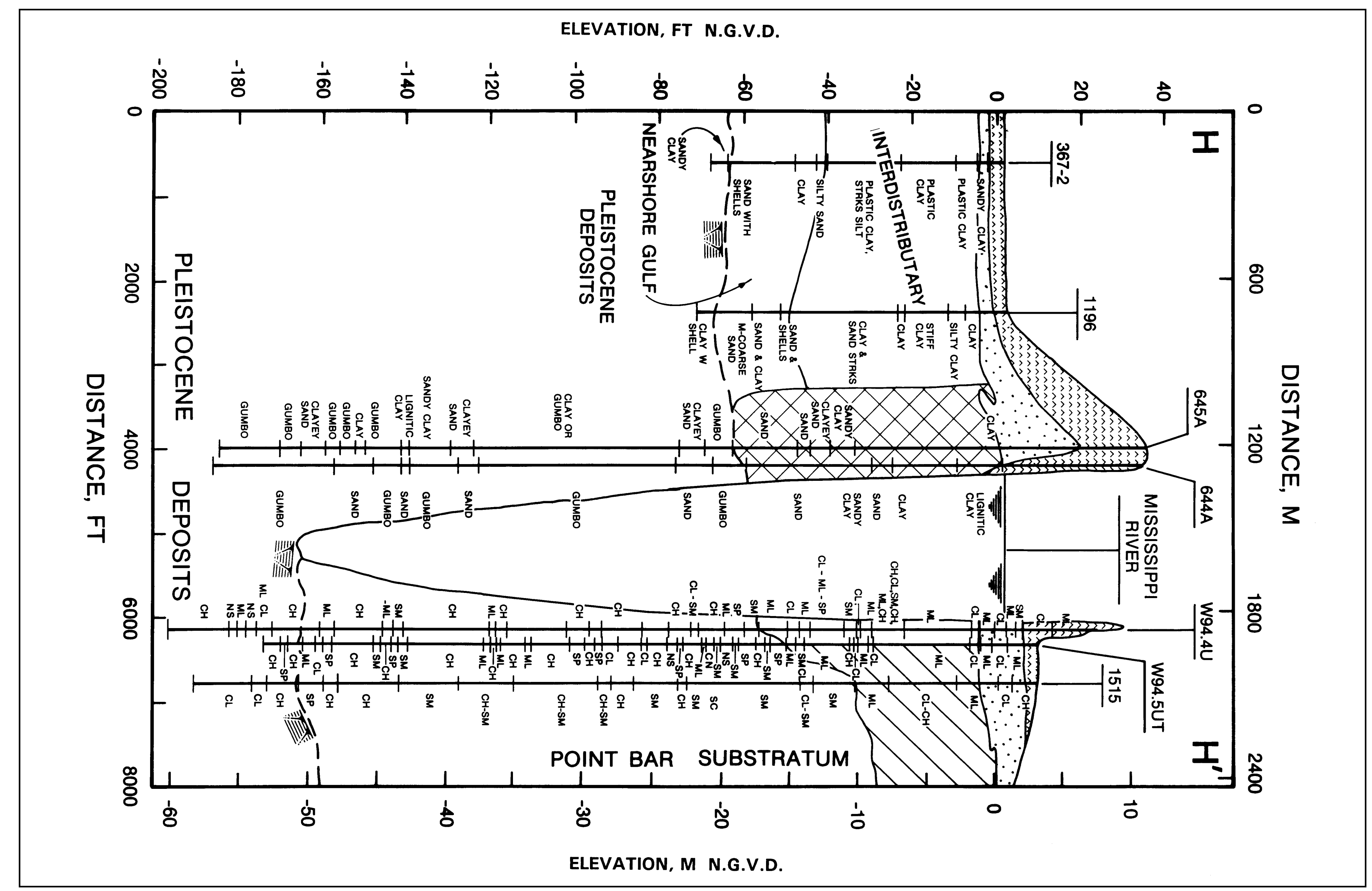

Figure 5k. Geologic cross section H-H' (see Figure 51 for symbol legend) 


\section{LEGEND}

\section{ENVIRONMENTS OF DEPOSITION}

TOPSTRATUM DEPOSITS

ER LEVEE FILL

Natural LEVEE

ZJ POINTBAR

$\triangle \backslash$ BACKSWAMP

ABANDONED COURSE

SUBSTRATUM DEPOSITS

UNDIFFERENTIATED

SAND AND GRAVEL

UPPER FINE-GRAINED

PLEISTOCENE SURFACE

SOIL TYPES (USCS)

$\begin{array}{lc}\text { CH - CLAY } & \text { SP - POORLY GRADED SAND } \\ \text { CL - SILTY CLAY, } & \text { SW - WELL-GRADED SAND } \\ \text { SANDY CLAY } & \text { GM - SILTY SAND-GRAVEL } \\ \text { ML - SILT, SANDY SILT, } & \text { GW - WELL-GRADED } \\ \text { CLAY SILT } & \text { SAND-GRAVEL } \\ \text { SC - CLAYEY SAND } & \text { GP - POORLY GRADED } \\ \text { SM - SILTY SAND } & \text { SAND-GRAVEL }\end{array}$

Figure 5l. Legend for the geologic sections of Figures $5 \mathrm{a}$ through $5 \mathrm{k}$ 


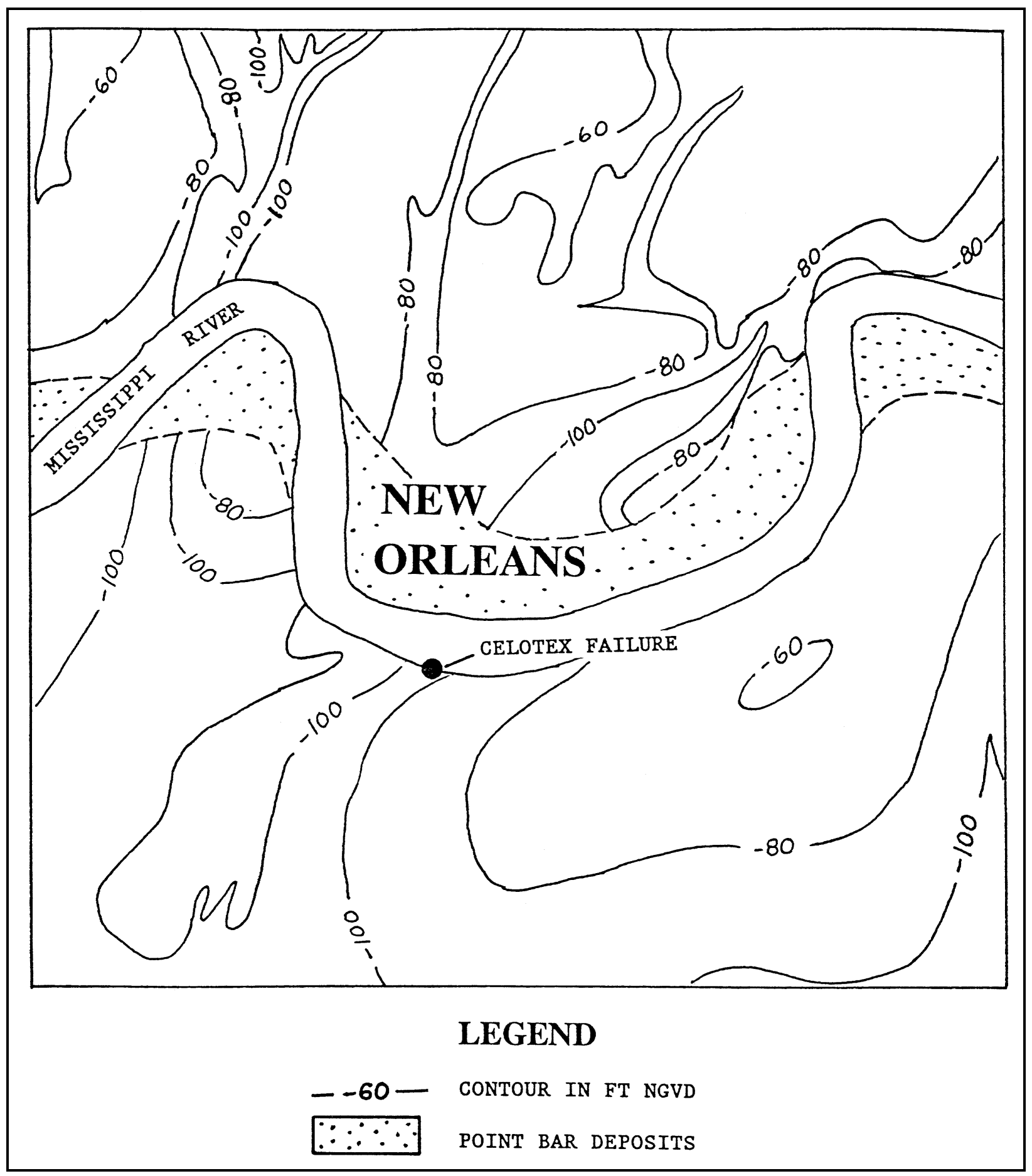

Figure 6. Generalized contour map of the Pleistocene surface (modified after Kolb, Smith, and Silva 1975)

Each of the different depositional environments present in the study area has distinct physical characteristics reflected by differences in soil types and associated engineering properties. Therefore, the geology of the study area will have a major influence on river scouring, lateral migration, and bank stability. 


\section{Geology of Selected Revetment Reaches}

\section{Celotex failure site and Greenville Bend revetment}

This riverbank reach extends from river mile 98.3 to 102.0 (158.2 to $164.1 \mathrm{~km}$ ) on the right descending bank. The subsurface geology of the Celotex failure site is shown by cross sections B-B' (Figure 5c) and F-F' (Figure 5i). The locations of these sections are shown in Figure 4. Areal photography and boring data identify a point bar sequence (Figure 4 and 5c) associated with Bayou des Familles (Figure 5i). This distributary channel was a major course of the Mississippi River during the active St. Bernard delta complex.

The exact intersection and lateral limits of Bayou des Familles at the Mississippi River are not well defined from areal photography because this area has been extensively developed by industrial and residential construction. The position and lateral extent of the Bayou des Familles channel at the Mississippi River was interpreted from available historic charts, maps, and boring data.

Soil types within the point bar-abandoned distributary sequence are primarily coarse-grained, consisting mainly of silty sands (SM) and well sorted or poorly graded sands (SP). The available boring data indicate that the point barabandoned distributary sequence extends approximately $100 \mathrm{ft}(30.5 \mathrm{~m})$ below the ground surface before encountering the oxidized and erosion-resistant Pleistocene surface.

The geology immediately upstream and downstream from the Bayou des Familles point bar sequence consists of interdistributary deposits underlain by a generally coarser nearshore gulf sequence (CL, ML, SM, and SC). Soil types are variable within these two depositional environments. Interdistributary sediments consist primarily of clay ( $\mathrm{CL}$ and $\mathrm{CH}$ ) with disseminated organics.

\section{Carrollton Bend and Carrollton Bend revetment}

This bank reach extends from about river mile 102.0 to 105.0 (164 to $169 \mathrm{~km}$ ) and encompasses the Carrollton Bend revetment which is on the left descending bank. The subsurface geology of the Carrollton Bend reach is shown on cross sections A-A' (Figure 5a), A'-A" (Figure 5b), and D-D' (Figure 5g) (see Figure 4 for section locations). The geology consists of natural levee, interdistributary, intradelta, and nearshore gulf sediments. Soil types are variable within the individual environments as shown by the cross sections. The Pleistocene surface ranges between elevations -50 to $-75 \mathrm{ft}(-15.2$ to $-22.9 \mathrm{~m})$ NGVD. Where the Mississippi River has entrenched itself into the Pleistocene, the river has formed thick point bar sediments in excess of $120 \mathrm{ft}(36.6 \mathrm{~m})$ deep.

\section{Gretna Bend and Gouldsboro revetments}

This revetted bank lies between river miles 95.5 and 98.3 (153.6 and $158.2 \mathrm{~km}$ ). The Gretna Bend and Gouldsboro revetments are contiguous from upstream to downstream, respectively, along the right descending bank. The 
subsurface geology of the Gretna Bend and Gouldsboro Revetment reach is shown by cross sections B'-B" (Figure 5d) and G-G' (Figure 5j) (see Figure 4 for section locations). The geologic sequence is similar to the two upstream revetment reaches already described. The Pleistocene surface ranges between elevations -55 to $-70 \mathrm{ft}(-16.8$ to $-21.3 \mathrm{~m}) \mathrm{NGVD}$ and is overlain by nearshore gulf, interdistributary, and natural levee sediments.

As shown by the surface geology map in Figure 4, there is an abandoned distributary channel which intersects the Mississippi River and extends southeast at approximately river mile $96.5(155.3 \mathrm{~km})$. The existence of this former distributary channel is indicated by the presence of well-developed natural levees several miles southeast of the Mississippi River. The intersection of this distributary channel with the present Mississippi River is indicated by boring W96.5GT. At this location, a thick sand sequence was encountered in the subsurface.

\section{Algiers Point revetment}

This revetment reach lies between river mile 93.7 and 95.5 (150.8 and $153.7 \mathrm{~km}$ ) on the right descending bank. The subsurface geology of Algiers Point is shown by cross sections C-C' (Figure 5e), C'-C' (Figure 5f), and H-H' (Figure 5k). The permanent scour pool along Algiers Point is one of the deepest of the Mississippi River entrenchment below Baton Rouge. River thalweg elevations have historically been between -175 and $-200 \mathrm{ft}(-53.3$ and $-61 \mathrm{~m})$ NGVD. At Algiers, along the point bar side of the river, fluvial scouring has created a 170-ft (51.8-m) thick point bar sequence (see cross section $\mathrm{H}-\mathrm{H}^{\prime}$ of Figure $5 \mathrm{k}$ ). Soil types are variable within this thick sequence, but are primarily coarse-grained.

Along the concave or left bank of the river, the subsurface geology at Algiers Point consists of interdistributary sediments, separated by point bar deposits and an abandoned interdistributary channel (see Figure 4 and cross section C-C' of Figure 5e). These sediments are underlain by the Pleistocene surface. The lateral and vertical limits of the different depositional environments are shown by the surface geology map and the respective geologic cross sections. Soil types are highly variable as defined by the sections.

The abandoned distributary channel shown in Figure 4 is a former St. Bernard distributary which branches from the main Bayou Sauvage-Metarie Bayou course northwest of Algiers Point. The intersection of this distributary channel at the Mississippi River is defined by coarse-grained sediments in the subsurface in borings located within the former distributary channel (see sections C-C' of Figure 5e and $\mathrm{H}-\mathrm{H}^{\prime}$ of Figure 5k). 


\section{Historic Mississippi River Migration}

\section{Bank Migration}

\section{Comparison procedure}

Bank migration during a 90-year period of record is examined in the following section. Seven different historic river surveys were compared to determine the magnitude of bank migration within the study reach. River surveys were made by the USACE at approximately 10-year intervals and were published as hydrographic surveys (USACE 1909, 1921; U.S. Army Engineer District, New Orleans (USAEDNO) 1938, 1952, 1965, 1976, and 1988). Bank comparisons are based on the low-water reference datum or its equivalent as identified in Table 1. Table 1 presents important characteristics from the different survey periods including survey year, reference datum (i.e., MSL, MGL, or NGVD), actual water surface elevation corrected to MSL (or NGVD) at the Carrollton staff gage (river mile $102.6(165.1 \mathrm{~km})$ ), and the map datum for the survey period.

Bank comparisons were made to identify and evaluate any historic changes which may have occurred in the study reach. Transparent overlays containing the historic bank configurations were prepared for each of the above hydrographic survey periods. These overlays were registered to a common datum (North American Datum) and scale $(1: 20,000)$. Because the total bank migration change through the study reach is rather limited, due in part to the underlying erosion resistant Pleistocene deposits which form the bed and banks of the river and because the river banks were revetted before the first surveys were conducted to prevent migration, comparisons are presented for only two selected time periods. Bank migration comparisons are shown only for the 1937 to 1984 and the 1894 to 1984 time periods in Figures 7a and 7b, respectively. 


\begin{tabular}{|c|c|c|c|}
\hline \multicolumn{4}{|c|}{$\begin{array}{l}\text { Table } 1 \\
\text { Hydrographic Survey Reference Data }\end{array}$} \\
\hline $\begin{array}{l}\text { Hydrographi } \\
\text { c } \\
\text { Survey Year }\end{array}$ & $\begin{array}{l}\text { Reference } \\
\text { Datum }^{1} \\
\end{array}$ & $\begin{array}{l}\text { Water Surface } \\
\text { Elevation }^{2}, \mathrm{ft}(\mathrm{m})\end{array}$ & Map Datum \\
\hline 1894 & $\begin{array}{l}\text { Mean Gulf Level } \\
\text { (Mean Water Surface) }\end{array}$ & $1.4(0.43)$ & $\begin{array}{l}\text { U.S. Coast } \\
1874 \text { Survey }\end{array}$ \\
\hline 1921 & $\begin{array}{l}\text { Mean Gulf Level } \\
\text { (Mean Water Surface) }\end{array}$ & $5.18(1.58)$ & $\begin{array}{l}\text { U.S. Coast } \\
1874 \text { Survey } \\
\text { Modified } 1921\end{array}$ \\
\hline 1938 & $\begin{array}{l}\text { Mean Gulf Level } \\
\text { (Mean Low Water) }\end{array}$ & $0.40(0.12)$ & $\begin{array}{l}\text { Gulf Coast or } \\
\text { Memphis Datum }\end{array}$ \\
\hline 1951 & $\begin{array}{l}\text { Mean Sea Level } \\
\text { (Mean Low Water) }\end{array}$ & $0.48(0.15)$ & $\begin{array}{l}\text { Gulf Coast or } \\
\text { Memphis Datum }\end{array}$ \\
\hline $1961-62$ & $\begin{array}{l}\text { Mean Sea Level } \\
\text { (Average Low-Water Plane) }\end{array}$ & $0.48(0.15)$ & $\begin{array}{l}\text { North American } \\
\text { Datum }\end{array}$ \\
\hline 1975 & $\begin{array}{l}\text { Mean Sea Level } \\
\text { (Low-Water Reference Plane) }\end{array}$ & $0.48(0.15)$ & $\begin{array}{l}\text { North American } \\
\text { Datum }\end{array}$ \\
\hline 1984 & $\begin{array}{l}\text { National Geodetic Vertical Datum } \\
\text { (Low-Water Reference Plane) }\end{array}$ & $0.36(0.11)$ & $\begin{array}{l}\text { North American } \\
\text { Datum }\end{array}$ \\
\hline \multicolumn{4}{|c|}{$\begin{array}{l}{ }^{1} \text { Mean Sea Level (MSL) is equivalent to National Geodetic Vertical Datum (NGVD). Mean Gulf } \\
\text { Level (MGL) prior to } 1899 \text { was referenced at } 8.13 \mathrm{ft} \text {, instead of the present } 6.083 \mathrm{ft} \text { on the Biloxi, } \\
\text { MS, staff gage. MGL in } 1921 \text { was referenced at } 6.63 \mathrm{ft} \text { on the Biloxi staff gage. } \\
{ }^{2} \text { The water surface is referenced to the Carrollton Bend staff gage (river mile } 102.6 \text { (165.1 m)) } \\
\text { and is corrected to MSL for all hydrographic survey periods except } 1984 \text {. The } 1984 \text { survey is } \\
\text { referenced to NGVD which is equivalent to MSL. The water surface elevations for the } 1894 \text { and } \\
1921 \text { surveys correspond to the river stage on the day of the survey, presumably at a low-water } \\
\text { stage. Bank lines prior to } 1921 \text { were surveyed for each hydrographic survey period independently } \\
\text { of river depth. However, for purposes of this report, comparisons between different hydrographic } \\
\text { survey periods are considered to be similar for use in the bank migration studies. }\end{array}$} \\
\hline
\end{tabular}

\section{Sources of error}

Water surface elevations referenced to the Carrollton Bend gage are the basis for the bank line comparisons. Sources of possible error in the bank comparisons are those dealing with the elevation of the water surface between survey periods (Table 1). River bank positions for the 1894 and 1921 surveys are based on the 1874 U.S. Coast Land Survey and are independent of river soundings or depths shown on the hydrographic survey. River soundings or depths shown on these two older surveys were made during the winter months and were referenced to the Carrollton Bend staff gage. It is assumed, although not stated on the 1894 and 1921 hydrographic surveys, that the river bank position is somehow calibrated to the low water datum and therefore referenced to the Carrollton Bend staff gage. Judging from the river bank position of these two earlier surveys, as compared to the more recent surveys, the earlier surveys are consistent with a similar low water datum as indicated by the bank comparison overlays and by the water surface elevations (Table 1). Hydrographic surveys after 1921 are standardized to a common low-water datum as indicated by Table 1 . Thus, the later surveys are considered to be relatively accurate for comparison purposes. 


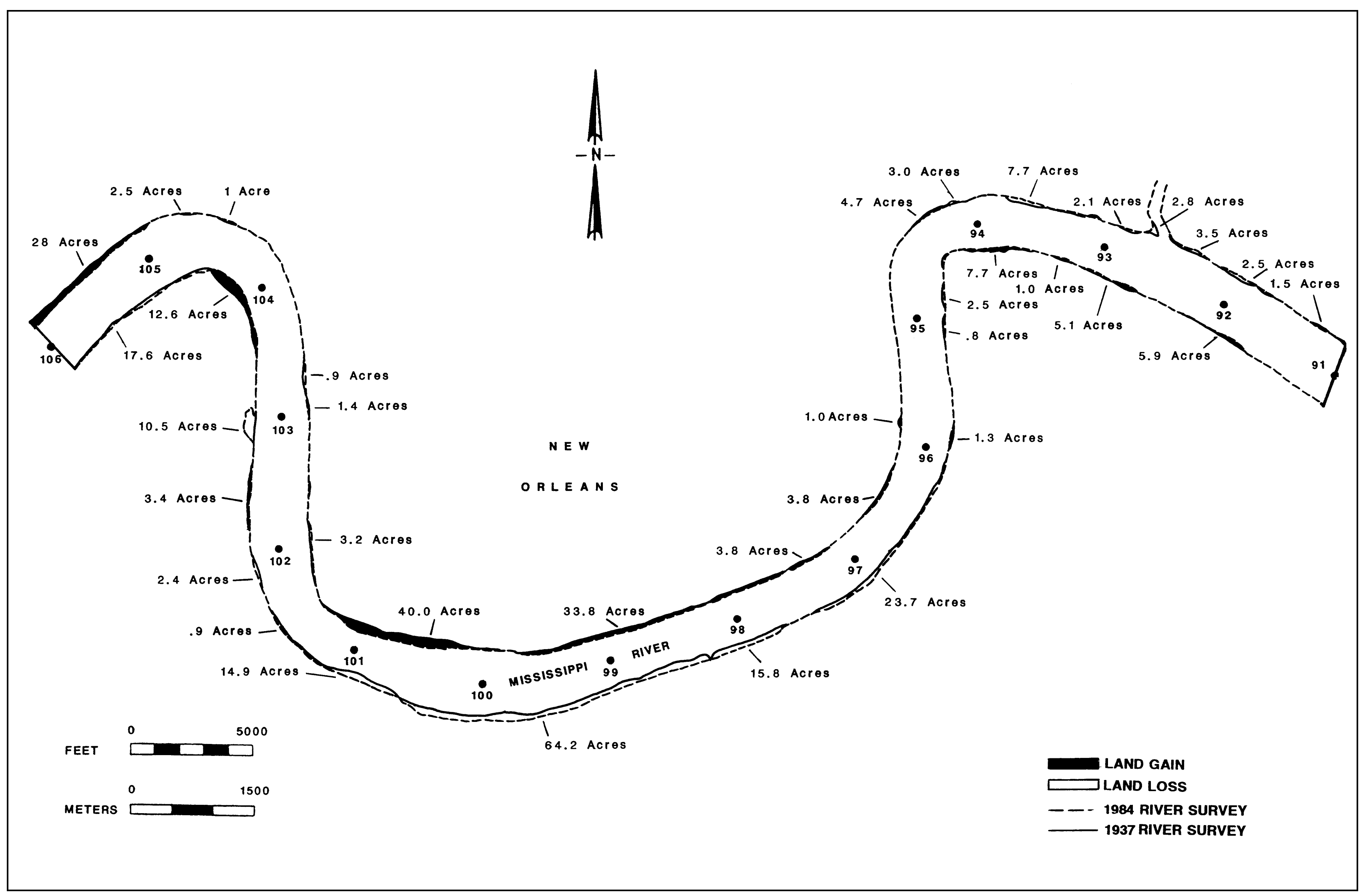

Figure 7a. Bank migration comparisons between 1937 and 1984 


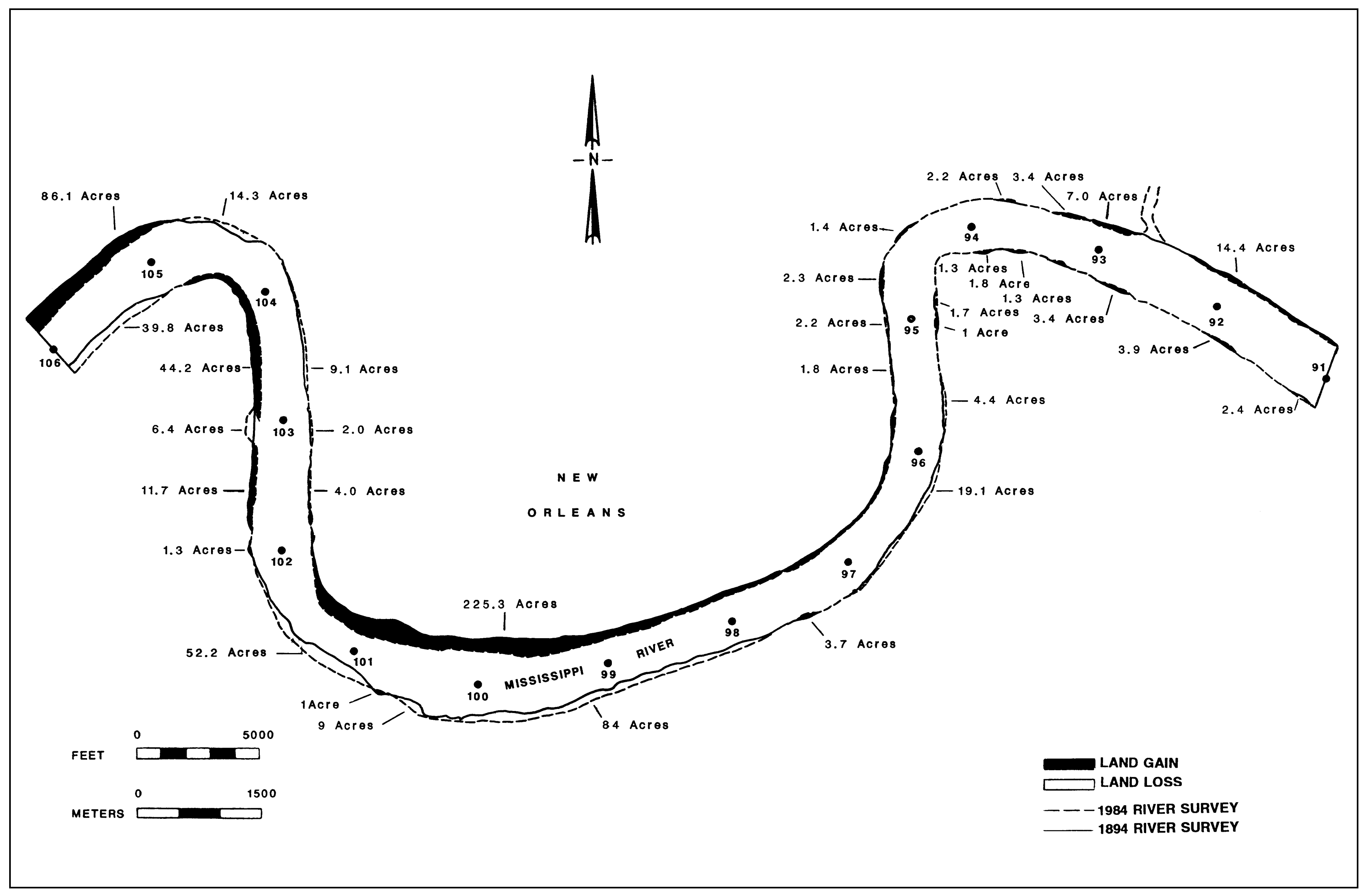

Figure Tb. Bank migration comparisons between 1894 and 1984

Chapter 3 Historic Mississippi River Migration

43 


\section{Historic bank migration}

Selected river bank comparisons in Figures $7 \mathrm{a}$ and $7 \mathrm{~b}$ contain sufficient area to show the trend and the magnitude of historic Mississippi River migration in the study area. Bank migration changes (i.e., areas of deposition and erosion) were digitized and measured by a computer program for each survey period evaluated. Examination of Figures $7 \mathrm{a}$ and $7 \mathrm{~b}$ shows the majority of change is occurring between river miles 99.0 and 102.0 (159.3 and $164.1 \mathrm{~km}$; Greenville Bend Revetment), 102.0 and 104.5 (164.1 and $168.3 \mathrm{~km}$; Carrollton Bend Revetment), and 104.5 and 106.0 (168.3 and $170.6 \mathrm{~km}$; Avondale Bend Revetment). River migration at the Avondale Revetment is to the southeast, at the Carrollton Bend Revetment, it is toward the northeast, and in the GreenvilleGretna Bend Revetments, toward the south (Figure 1).

Total areal changes for each bank for the 15 -mile $(24-\mathrm{km})$ reach of river under study are identified in Tables 2 and 3 for the 1937 to 1984 and the 1894 to 1984 survey periods, respectively. Gain and loss acreages identified for each river bank in Figures $7 \mathrm{a}$ and $7 \mathrm{~b}$ represent a single polygon consisting of two intersecting bank lines. The area bounded by the intersecting bank lines contains a beginning and ending node that separates it from the next adjacent polygon area. Thus, each individual polygon identified on the preceding illustrations represents a unit area of gain or loss. Total areal changes by river bank are identified in Tables 2 and 3.

\begin{tabular}{||l|l|l|l||}
\hline \hline $\begin{array}{l}\text { Table 2 } \\
\text { Bank Movement Between 1937 and 1984 }\end{array}$ \\
\hline \hline River Bank & $\begin{array}{l}\text { Erosion (E) } \\
\text { (acres) }\end{array}$ & $\begin{array}{l}\text { Deposition (D) } \\
\text { (acres) }\end{array}$ & E/D Ratio \\
\hline \hline Right (West) & 170.9 & 33.6 & 5.09 \\
\hline Left (East) & 27.2 & 118.6 & 0.23 \\
\hline Total & 198.1 & 152.2 & 1.30 \\
\hline
\end{tabular}

\section{Table 3}

Bank Movement Between 1894 and 1984

\begin{tabular}{||l|c|l|l||}
\hline \hline River Bank & $\begin{array}{l}\text { Erosion (E) } \\
\text { (acres) }\end{array}$ & $\begin{array}{l}\text { Deposition (D) } \\
\text { (acres) }\end{array}$ & E/D Ratio \\
\hline \hline Right (West) & 216.6 & 339.9 & 0.64 \\
\hline Left (East) & 35.6 & 73.2 & 0.48 \\
\hline Total & 252.2 & 413.1 & 0.61 \\
\hline
\end{tabular}

Examination of Figures $7 \mathrm{a}$ and $7 \mathrm{~b}$ shows that river migration is confined to selected reaches with nearly equal gain and loss at each bendway. For the 1937 to 1984 time period, erosion was the dominant process (Table 2). Similarly, for the 1894 to 1984 time period, deposition was the dominant process (Table 3). Thus, over the long term, deposition or land gain has been the dominant surface expression of bank movement in the study area. 
Another view of historic river migration in the study area is shown by Figures $8 \mathrm{a}$ and $8 \mathrm{~b}$. Bank migration distances were measured at selected survey locations to show the relative movement that has occurred throughout the study area. A separate graph is presented for each river bank in Figures $8 \mathrm{a}$ and 8b. A positive value in the graphs represents deposition or land gain, while negative values correspond to erosion and land loss. The majority of change is occurring between river miles 97 through 106 (156.1 through $170.6 \mathrm{~km})$. The largest movement has occurred at river miles 101 and 106 (162.5 and $170.6 \mathrm{~km})$.

Two important historic trends are shown by the preceding illustrations. The first trend involves the relative magnitude of erosion as compared to deposition. Historically, deposition or land gain has been the dominant process with the magnitude of gain being far greater than the corresponding loss. At only two locations, i.e., river mile 101 and $106(162.5$ and $170.6 \mathrm{~km})$, does erosion exceed $500 \mathrm{ft}(152.4 \mathrm{~m})$ of movement. In contrast, the number of locations (or the amount of area under the curve) where deposition exceeds $500 \mathrm{ft}(152.4 \mathrm{~m})$ of total movement is substantially greater. Bank comparison data suggest that the general historic trend has been an overall reduction in channel width.

The other important trend which the migration data show is the historic implication for the Celotex failure area. The Celotex failure site has experienced almost no movement during the past 100 years. Compare this lack of movement with the surrounding area and the opposite (left) river bank. At the Greenville Bend revetment reach, river mile 97 to 103 (156.1 to $165.8 \mathrm{~km}$ ) is a zone of significant historic migration. Within this reach there is an area that has remained stable except for recent movement at the Celotex failure site. Figure 8a (left bank) indicates that erosion and further bank movements should occur at the Celotex reach (Figure 8b) since the point bar side of the river has experienced significant land accretion. Based on geologic and historic data, it appears that revetment maintenance has generally been successful at this location.

Assuming that discharge conditions have remained similar between the two survey periods, then in order for a gain in land area to occur, the channel morphology must become narrower and deeper in order to maintain a constant channel cross-sectional area. Under equilibrium conditions, land gain and bank loss should be the same providing that flow conditions have been constant. Historic hydrographic survey data indicate that over the long term, bank gain has exceeded bank loss in the study area (Table 3).

Comparisons shown in Tables 2 and 3, Figures $7 \mathrm{a}, 7 \mathrm{~b}, 8 \mathrm{a}$, and $8 \mathrm{~b}$ indicate that erosion or deposition may dominate during the short term, but over the long term these opposing processes should attain an equilibrium state. Historic data indicate that bank migration occurs as a series of discrete bank movements or failures, separated by longer periods of inactivity. During inactive periods, bank attack occurs by scouring in the channel bed and vertical incision. With time the toe of the river bank is undermined, the upper bank becomes unstable, the failure process repeats itself, and the channel migrates laterally. This cycle is again repeated and the river migrates across its floodplain. This simplistic 


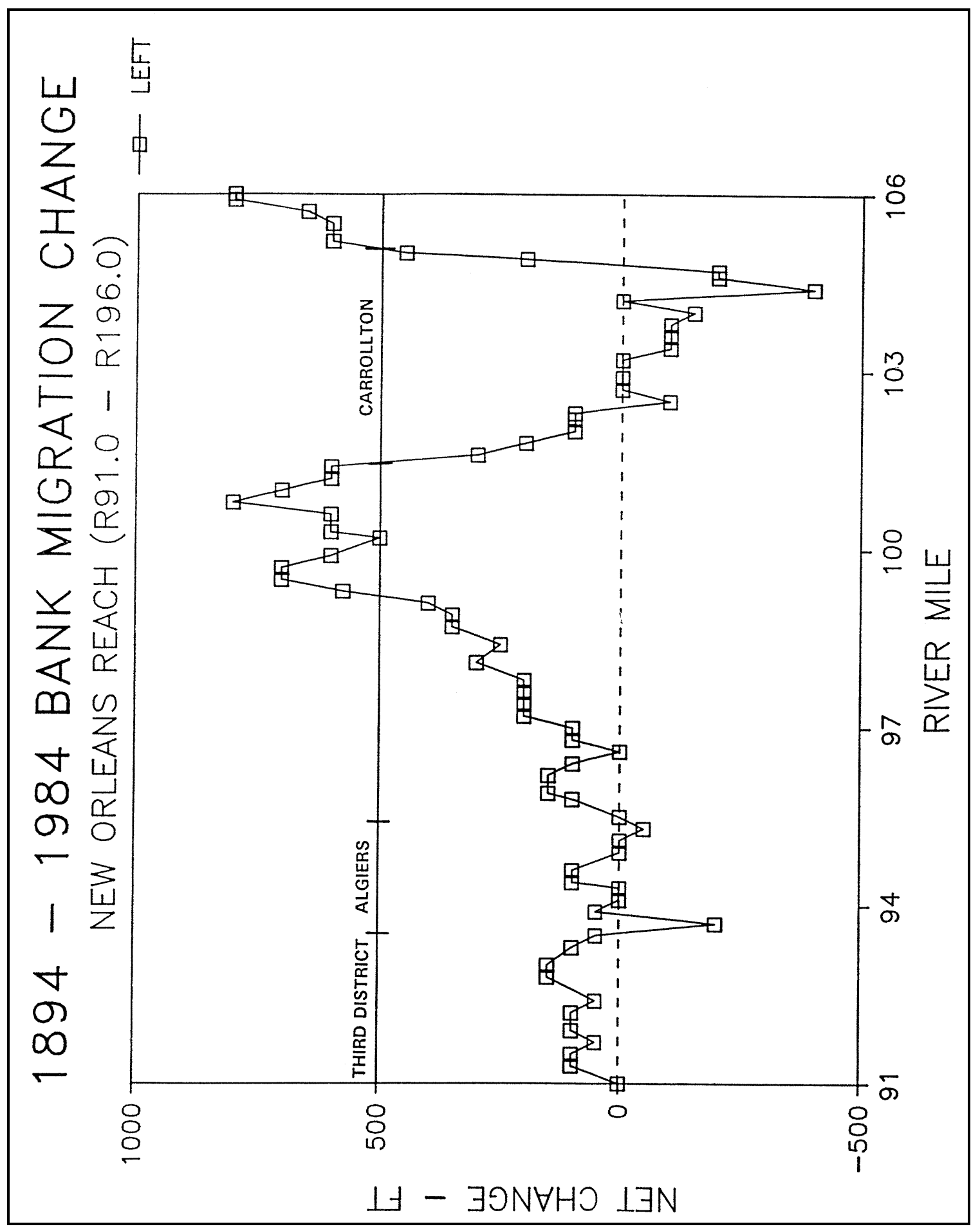

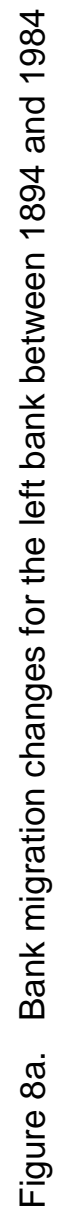




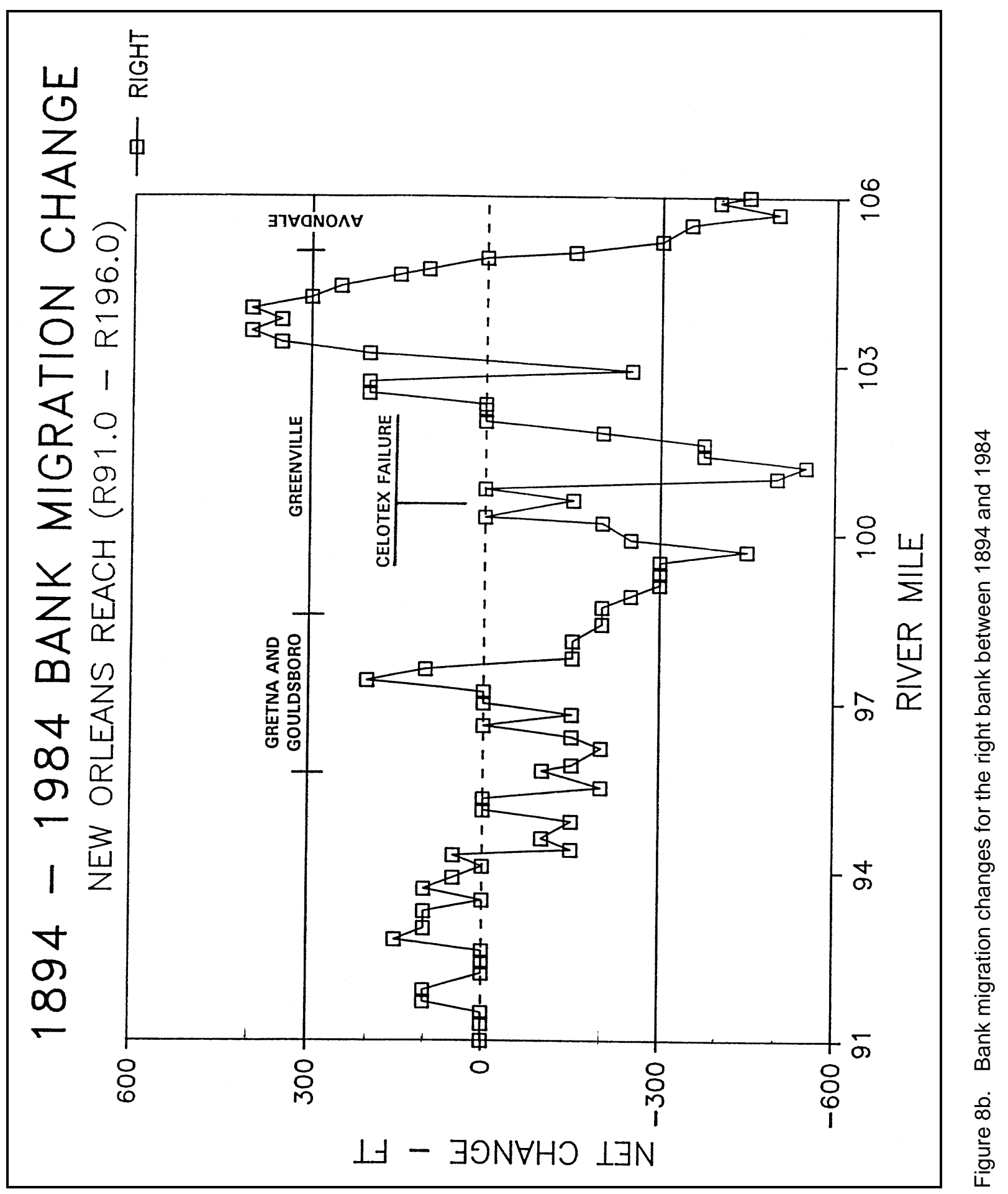


model will be examined in more detail in Chapter 5 of this report where a failure mechanism will be evaluated with respect to the available data.

In summary, the historic response of the reach of river under study has been a reduction in channel width at the bendways and deposition dominating for the long-term period of record. The next section of this report will evaluate the channel bed of the river to gain an understanding of historic river changes in the channel.

\section{Scour Pool Migration}

\section{Thalweg profile}

A thalweg profile for the entire study reach is shown in Figure 9a and individually for the associated scour pools in Figures 9b through 9f (Carrollton Bend, Figure 9b; Greenville Bend, Figure 9c; Gretna Bend, Figure 9d; Gouldsborro Bend, Figure 9e; and Algiers Point, Figure 9f). Maximum scour pool depth and length are shown by the thalweg profiles. Profile depths refer to lowwater surveys and are referenced to a low-water reference plane (Table 1). The thalweg of the river is the deepest point in the channel. A thalweg profile represents a cross section of the deepest points in the river at each survey location for each respective survey period. Thalweg profiles in Figures 9a through $9 f$ are plotted according to river mile. River miles were interpreted for the older hydrographic surveys as these surveys were referenced by distance from the Cairo Datum. River mile interpretation in the older hydrographic surveys should be relatively accurate considering there hasn't been much channel migration in the study area.

River depth variability and the general historic trend at each scour pool are shown by the thalweg profiles. Examination of Figure 9a shows that in the New Orleans reach there are three major scour pools that are deeper than el $-150 \mathrm{ft}$ $(-45.7 \mathrm{~m})$ NGVD. The deepest pool in the study reach is at Algiers Point. The maximum depth at Algiers Point was at el -208 ft (-63.4 m) NGVD and occurred during the 1938 survey period. For the most recent survey period, the maximum occurs at Greenville Bend with a scour pool depth near el -200 ft (-61 m) NGVD. The Celotex failure is located along the downstream margin of the Greenville Bend scour pool (Figure 9c).

The degree of change that has occurred in the study area is illustrated in Figures 9a through 9f with the 1984 survey as a base, and comparing this profile to past thalweg profiles. The 1984 survey represents either the historic maximum depth or is generally close to the maximum. Greenville Bend has the maximum depth in the study reach for the 1984 survey. At Carrollton Bend, the maximum depth is occurring along the downstream margin of this pool. Various other 1984 survey locations in Figure 9a are at their historic maximum. The preceding thalweg profiles generally support an earlier observation in that the channel of the Mississippi River becomes deeper as the channel narrows. 


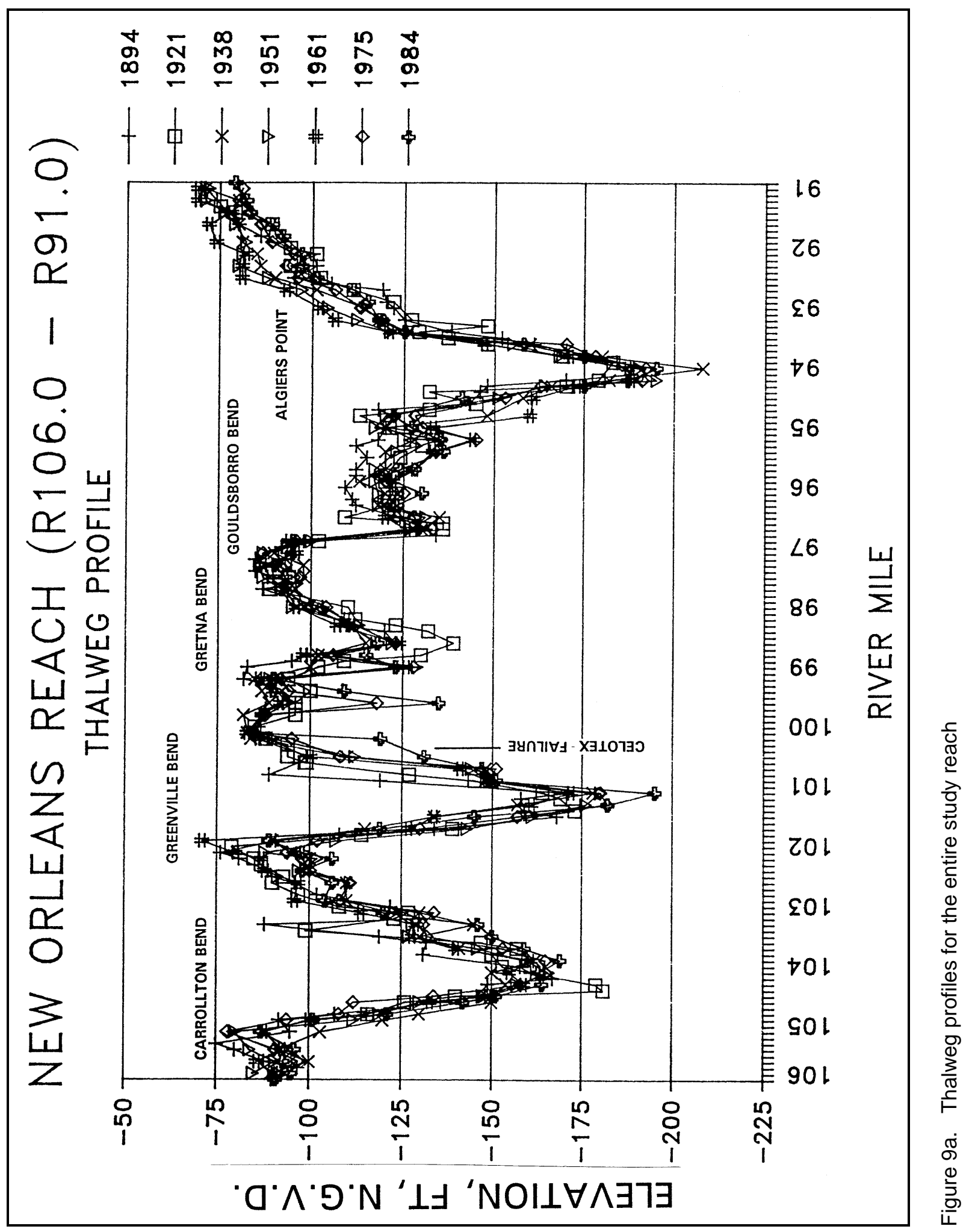




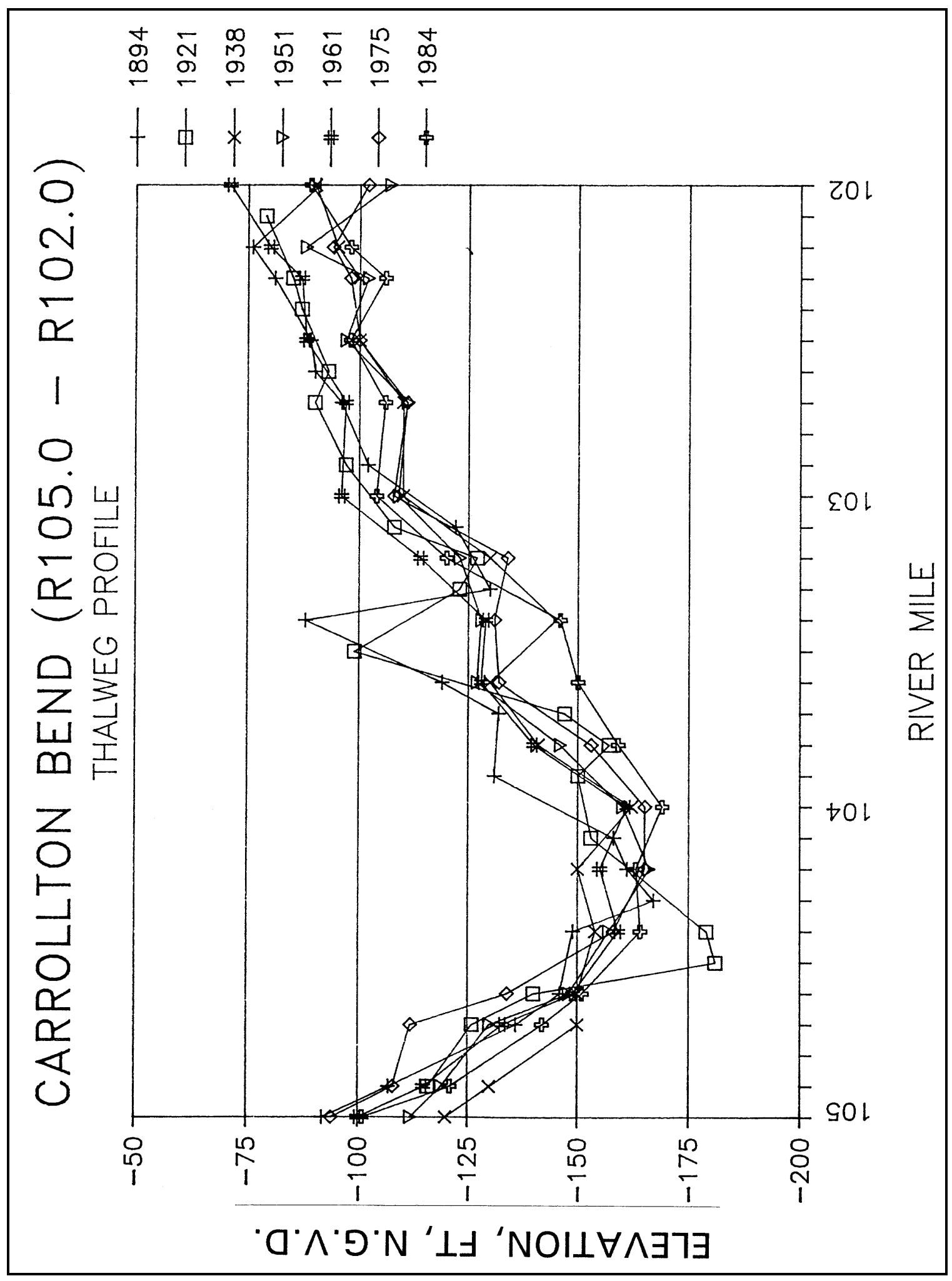

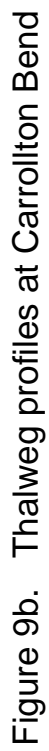




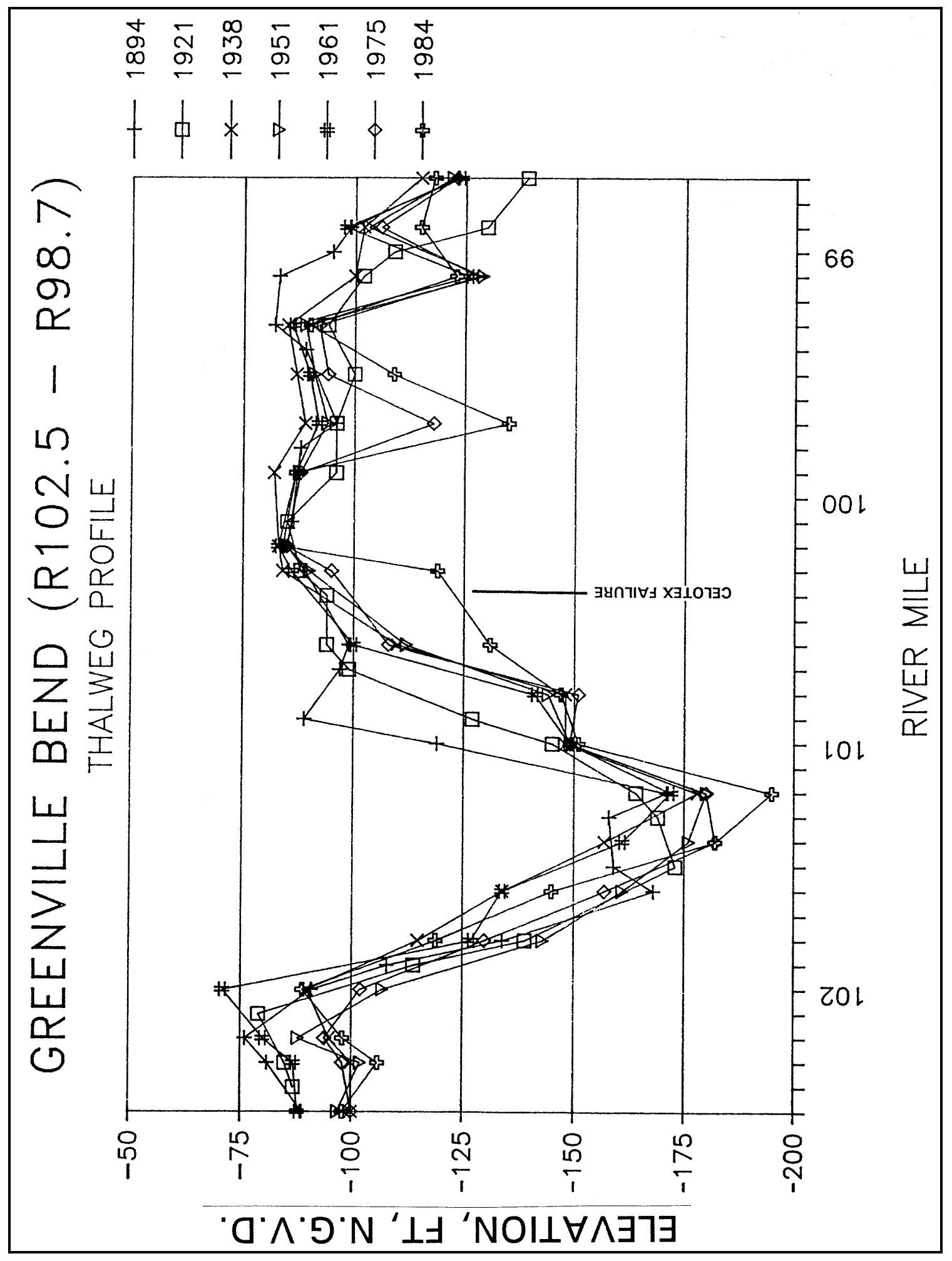

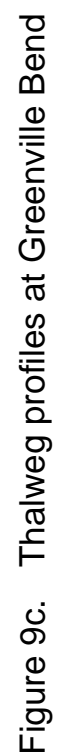




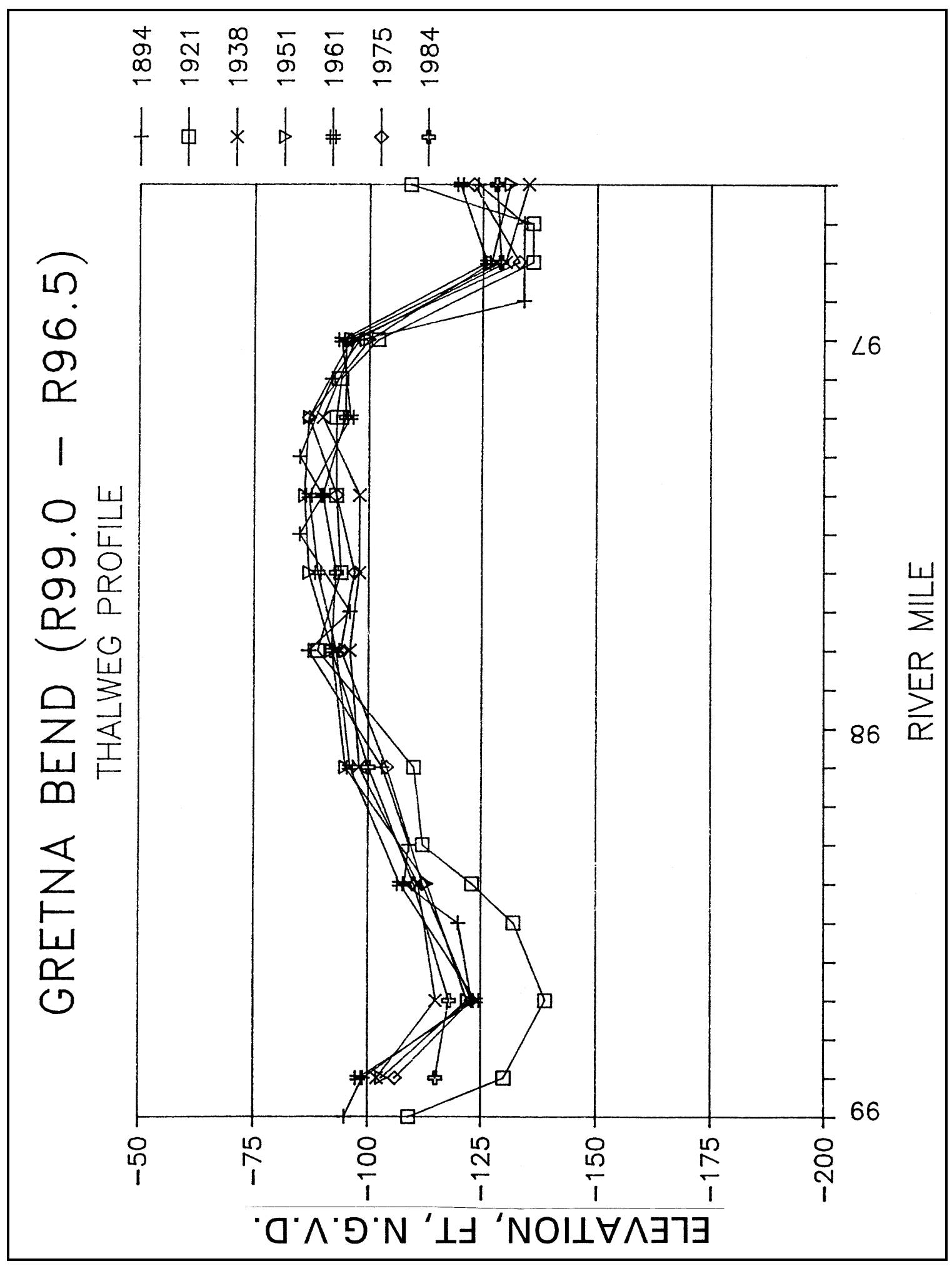

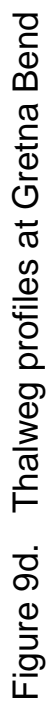




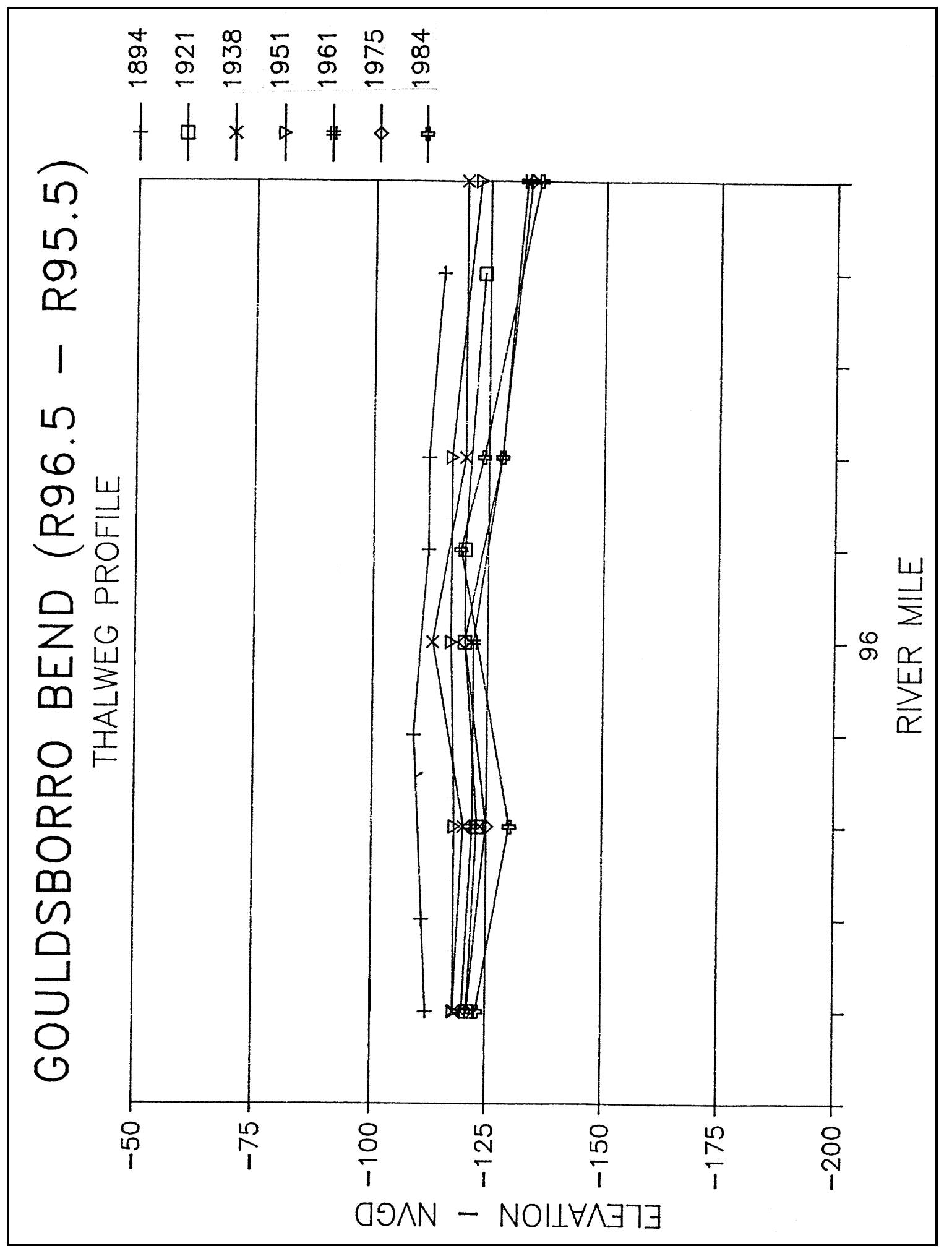

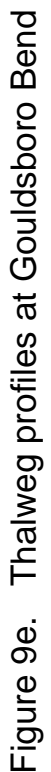




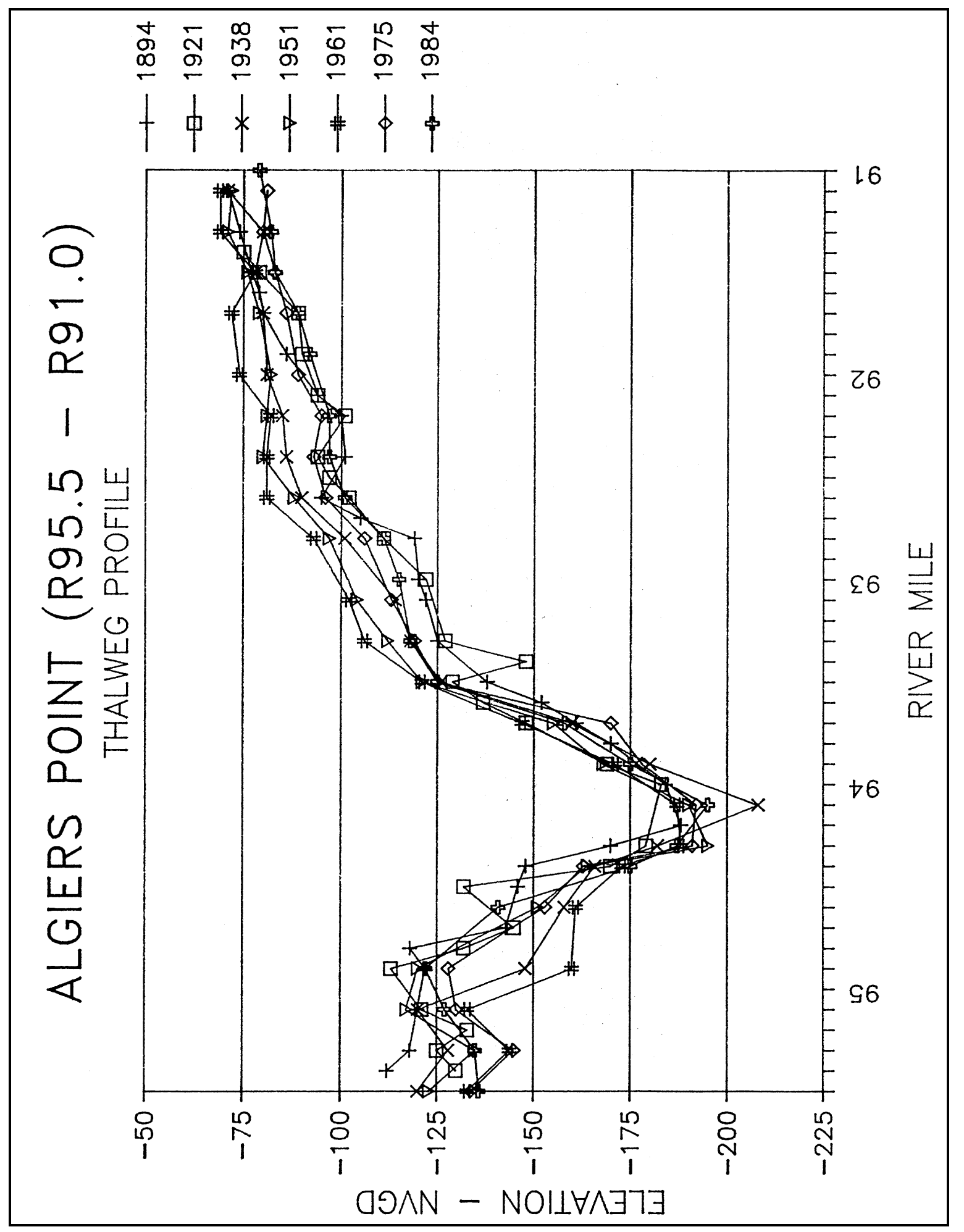

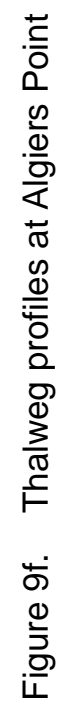


Closer examination of Figure 9a shows that the scour pools at Carrollton and Greenville Bends have both moved slightly downstream during the period of record. The remaining three scour pools, Gretna Bend, Gouldsborro Bend, and Algiers Point, have remained fairly stable during the past 90 years with respect to downstream movement. The relative magnitude of downstream migration at Carrollton and Greenville bends is best shown by the separate thalweg profiles for the individual scour pools (Figure $9 b$ and $9 c$ ). At Greenville Bend (Figures 9a and 9c), historic thalweg profiles indicate that downstream pool migration and enlargement has occurred.

The Celotex failure site is located within the Greenville bend scour pool area, along the downstream margin of the zone where maximum movement has occurred. Considering the overall nature of the geology at this site (Figure 5c), the historic channel migration (Figure 8b), and the distribution of thalweg profiles at this location (Figure 9c), the Greenville Bend reach will be an area to monitor because it has indicated instability in the past.

\section{Pool migration}

Historic scour pool migration patterns within the study reach are shown by Figures 10 and 11. Scour pool outlines are shown by Figures 10a through 10c for the $-100-\mathrm{ft}(-30.5-\mathrm{m})$ contour and Figures 11a through 11c for the $-150-\mathrm{ft}$ $(-45.7-\mathrm{m})$ contour. Figures 10 through 11 identify the most recent survey as being 1985 (USAEDNO 1988), while the actual survey in the New Orleans reach was conducted during 1984. For discussion purposes, the most recent survey is referred to as the 1984 survey or contour.

Examination of the $-100-\mathrm{ft}(-30.5-\mathrm{m})$ contour outline (Figures 10a through 10c) shows well established scour pools at each bend of the river. Large-scale movements of the $-100-\mathrm{ft}(-30.5-\mathrm{m})$ pool have generally not occurred during historic time. Instead, there has been a general tendency for the pools to enlarge in the downstream direction and, as would be expected, migrate toward the concave or cutbank side. The most significant scour pool in the study reach, in terms of its size, is at Algiers Point. This scour pool extends approximately from river mile 92.6 to 97.0 (149.0 to $156.1 \mathrm{~km})$. This pool incorporates two bendways of the river.

The -150-ft (-45.7-m) contour outline (Figures 11a through 11c) is a better measure of pool stability for comparison between different surveys. The $-150-\mathrm{ft}$ $(-45.7-\mathrm{m})$ contour shows the basic historic trend at each bendway and is less detailed than the $-100-\mathrm{ft}(-30.5-\mathrm{m})$ outline. There are only three scour pools present with depths greater than el $-150 \mathrm{ft}(-45.7 \mathrm{~m})$ : Carrollton, Greenville, and Algiers Point. A similar pattern emerges for the $-150-\mathrm{ft}(-45.7-\mathrm{m})$ contour as previously noted for the $-100 \mathrm{ft}(-30.5 \mathrm{~m})$ contour. There has been no significant migration of these major scour pools within the study reach.

Some general observations about each of the three major pools are described below:

a. Carrollton Bend. This pool has remained stable over the period of record. There has been no migration of the scour pool at this location. 


$$
\text { 道事 }
$$




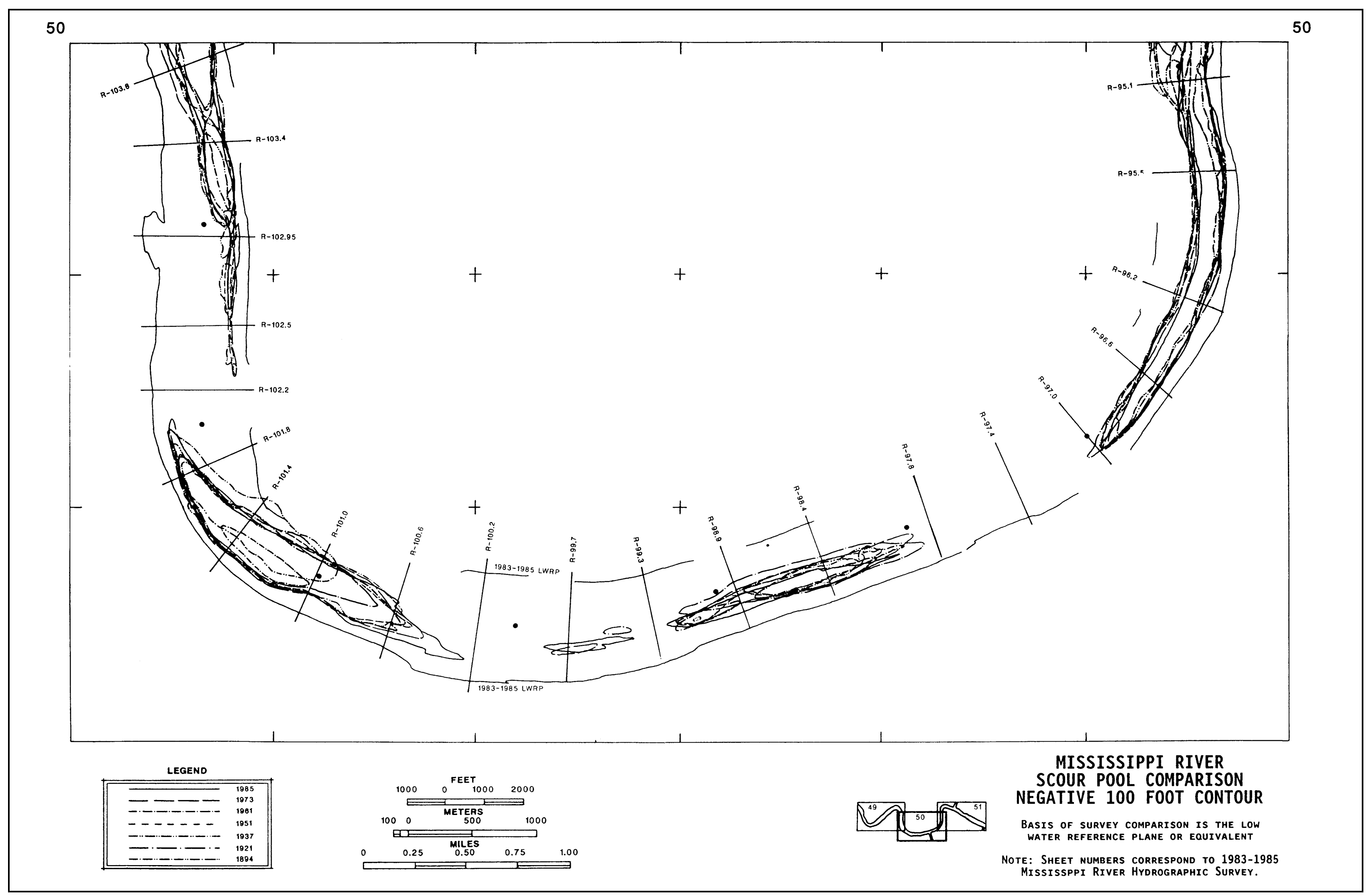

Figure 10b. Scour pool comparisons for the $-100-\mathrm{ft}(-30.5-\mathrm{m})$ contour from river mile 103.8 to 95.0 


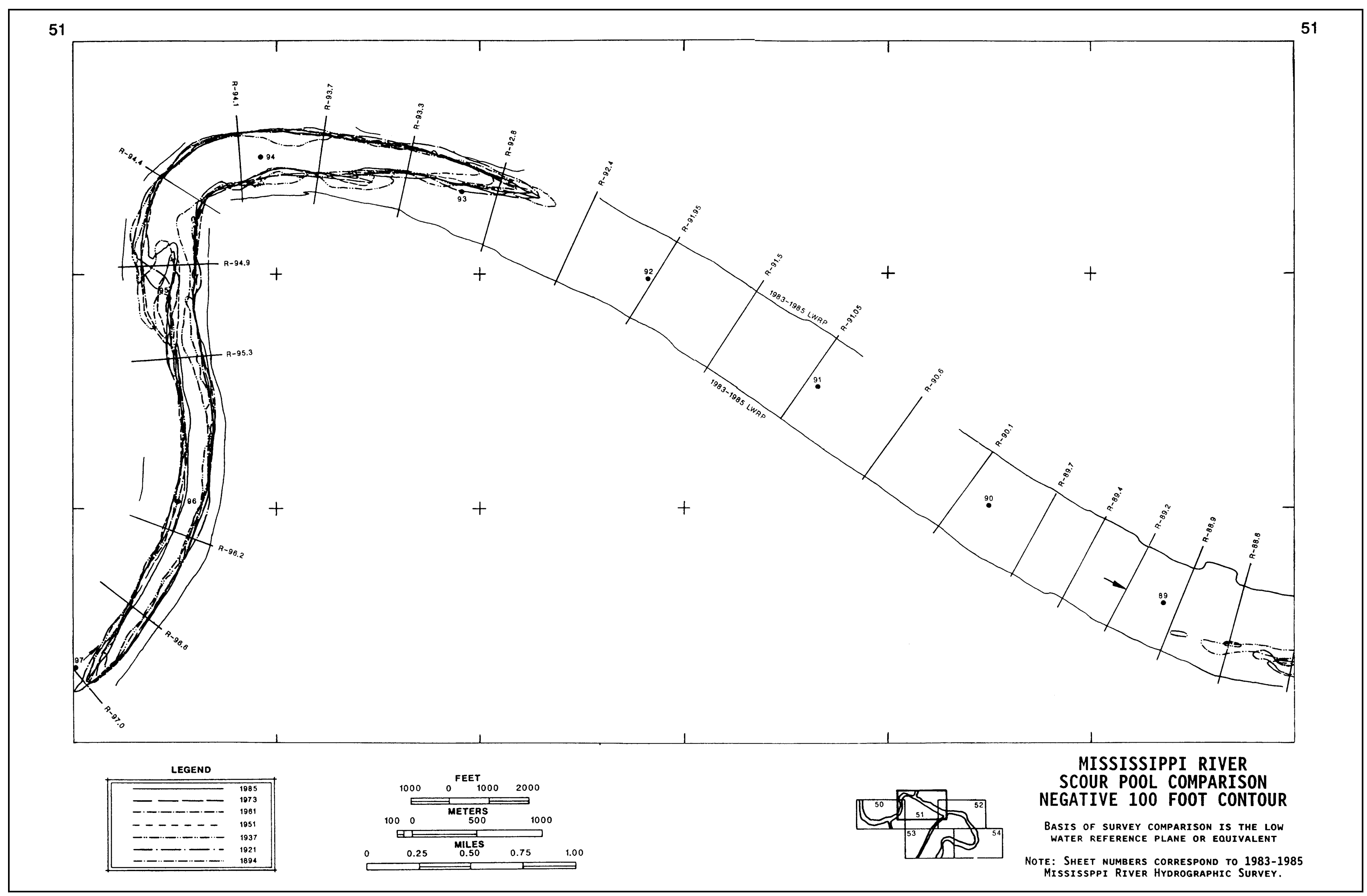

Figure 10c. Scour pool comparisons for the $-100-\mathrm{ft}(-30.5-\mathrm{m})$ contour from river mile 97.0 to 88.6 


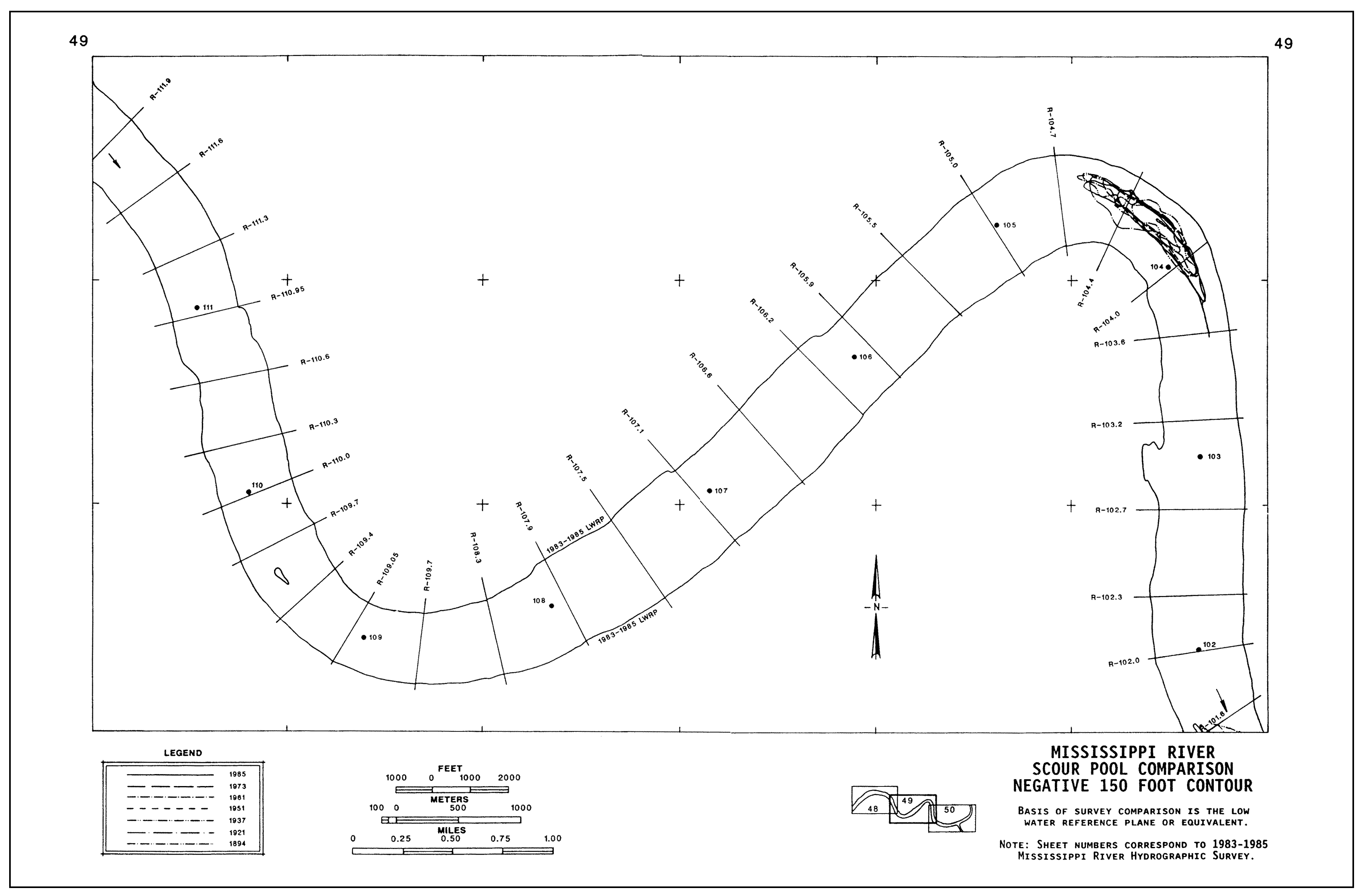

Figure 11a. Scour pool comparisons for the $-150-\mathrm{ft}(-45.7-\mathrm{m})$ contour from river mile 111.9 to 101.8

Chapter 3 Historic Mississippi River Migration

63 


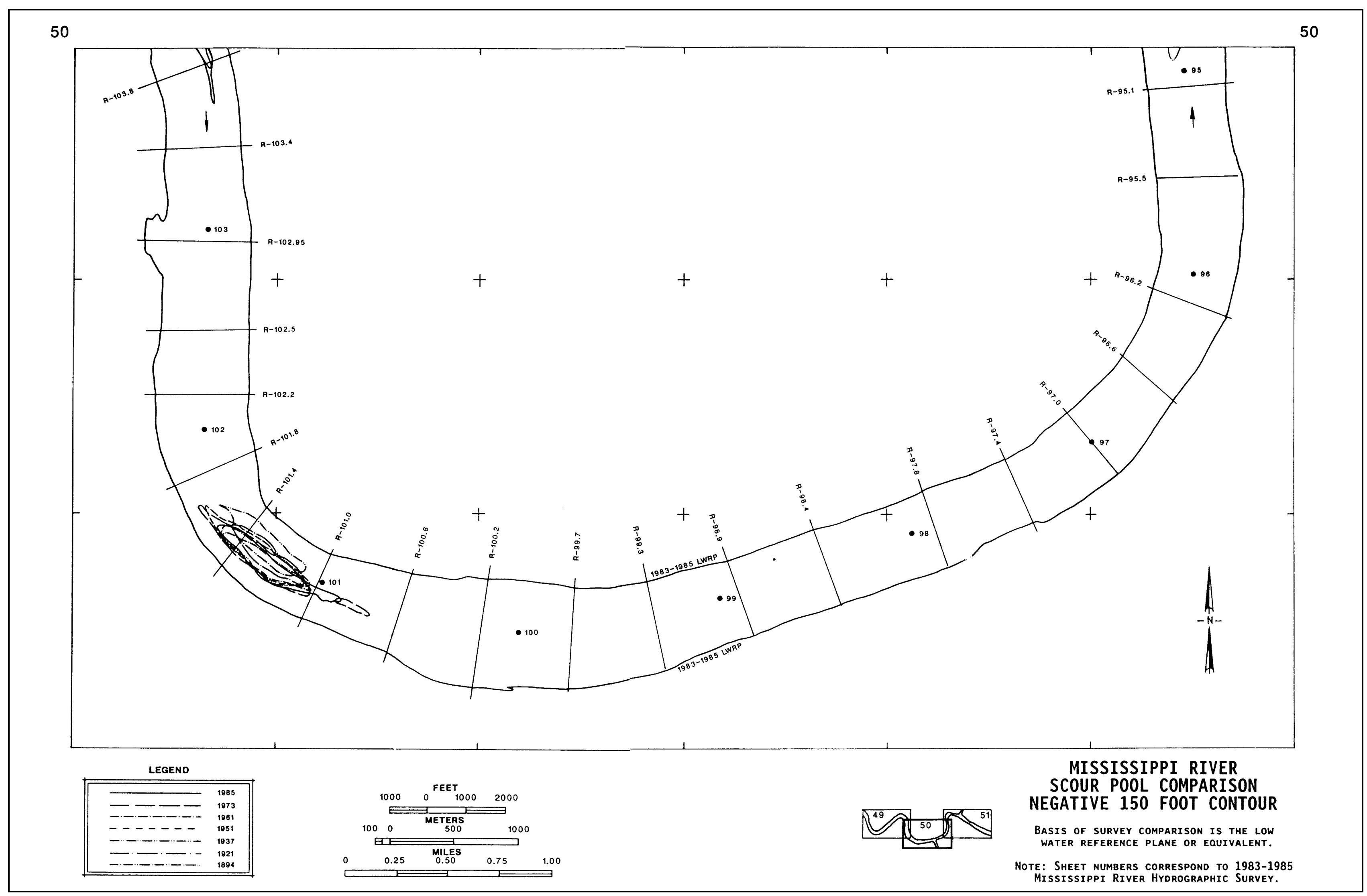

Figure 11b. Scour pool comparisons for the $-150-\mathrm{ft}(-45.7-\mathrm{m})$ contour from river mile 103.8 to 95.0 


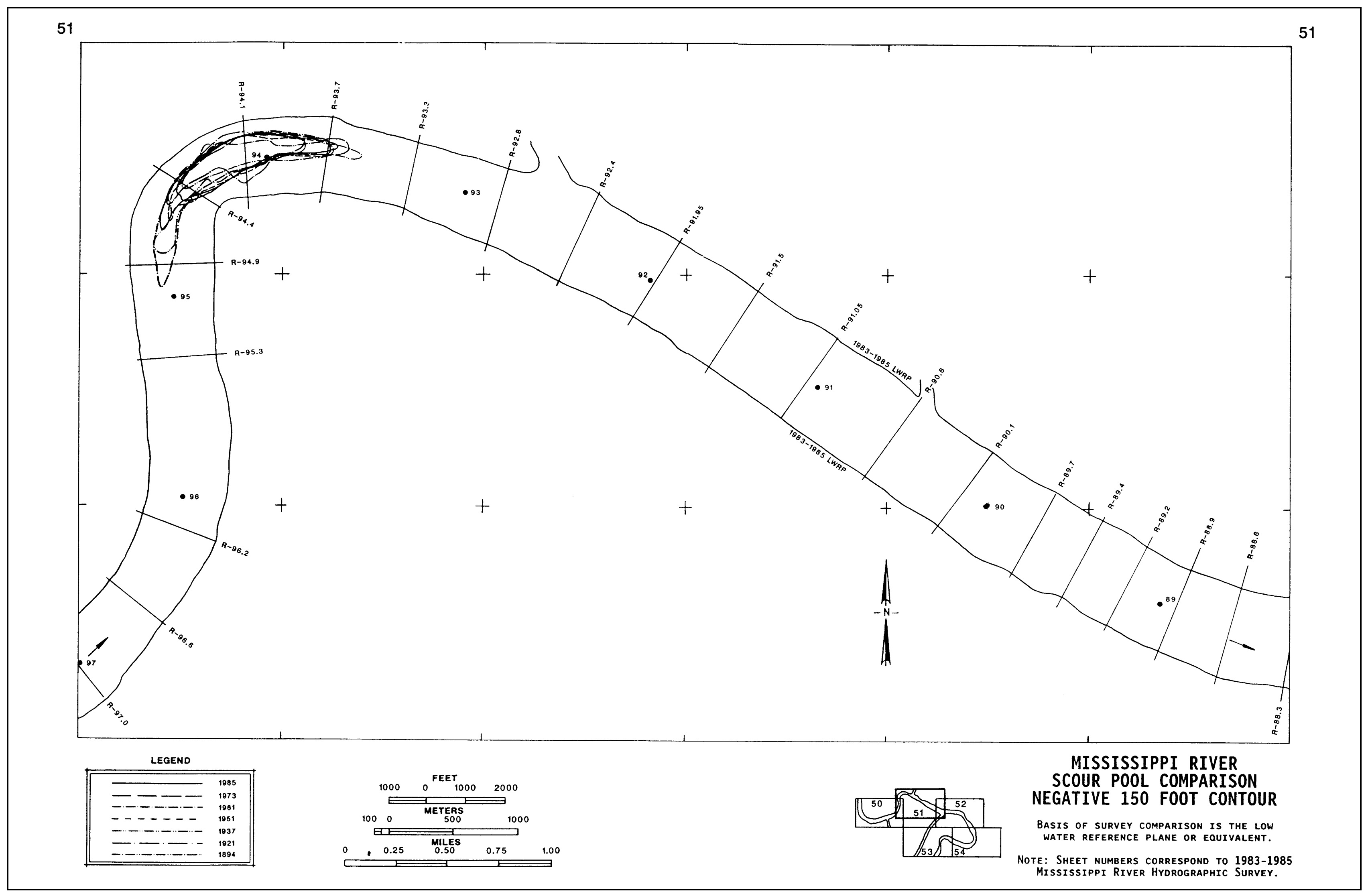

Figure 11c. Scour pool comparisons for the $-150-\mathrm{ft}(-45.7-\mathrm{m})$ contour from river mile 97.0 to 88.6

Chapter 3 Historic Mississippi River Migration

67 
b. Greenville Bend. This pool has experienced the most lateral migration, both bankward and downstream as indicated by the 1984 contour (Figure 11b). The 1984 contour shows that the Greenville Bend scour pool has shifted slightly downstream and become one pool instead of two separate pools as in the 1973 survey.

c. Algiers Point. A decrease in size occurs in 1984 from its historic maximum in 1961. The pool has shifted slightly toward the center of the channel and away from the left river bank as compared to its 1894 position. The Algiers Point pool is one of only a few locations below Baton Rouge, LA, that has scoured below $-200 \mathrm{ft}(-61 \mathrm{~m})$ NGVD during the past 100 years. This maximum occurred in 1937 and has not been repeated subsequently during any other hydrographic survey event (Figures 9a and 9f). It should be noted, however, the depth at this pool has been close to this value, ranging between el -170 and $-195 \mathrm{ft}(-51.8$ and $-59.4 \mathrm{~m})$ before and after 1937. 


\section{Mississippi River Channel Morphology}

\section{Entire Study Reach}

\section{Procedure}

Width to depth (W:D) ratios represent a simple and convenient method to measure and compare channel shape or morphology. W:D ratios were calculated for the study reach from the 1894 and 1984 hydrographic surveys. W:D ratios represent the width of the river divided by the maximum depth of the river at each survey location. River measurements are based on the low-water reference plain or its equivalent and were calculated for the study reach between river miles 91 to 106.

Statistical parameters (i.e., mean and standard deviation) were calculated from the W:D values for the two survey periods evaluated. W:D ratios were ranked according to their mean and standard deviation as shown by the frequency histograms of $\mathrm{W}: \mathrm{D}$ values in Figure 12. Low W:D ratios generally correspond to a narrow and deeper channel. Higher W:D values correspond to shallower and wider river reaches.

\section{Morphology}

Comparison of the two frequency histograms in Figure 12 indicate that historic changes in channel morphology have occurred in the study reach. W:D ratios were generally much higher in 1894 as compared to 1984 . There has been a 17.5 percent decrease in the mean and 19.6 percent decrease in the standard deviation between the 1894 and 1984 surveys. The number of channel locations below the mean value has increased for the 1984 survey. The river through the study reach has generally become deeper. There has been channel deepening at 62 percent of the surveyed sites in 1984 as compared to the same sites in the 1894 survey.

River locations for W:D ratios below the mean value for each survey are presented in Figures 13a through 13c. Locations shown in Figures 13a through $13 \mathrm{~b}$ correspond only to their river mile location and not to their position in the 


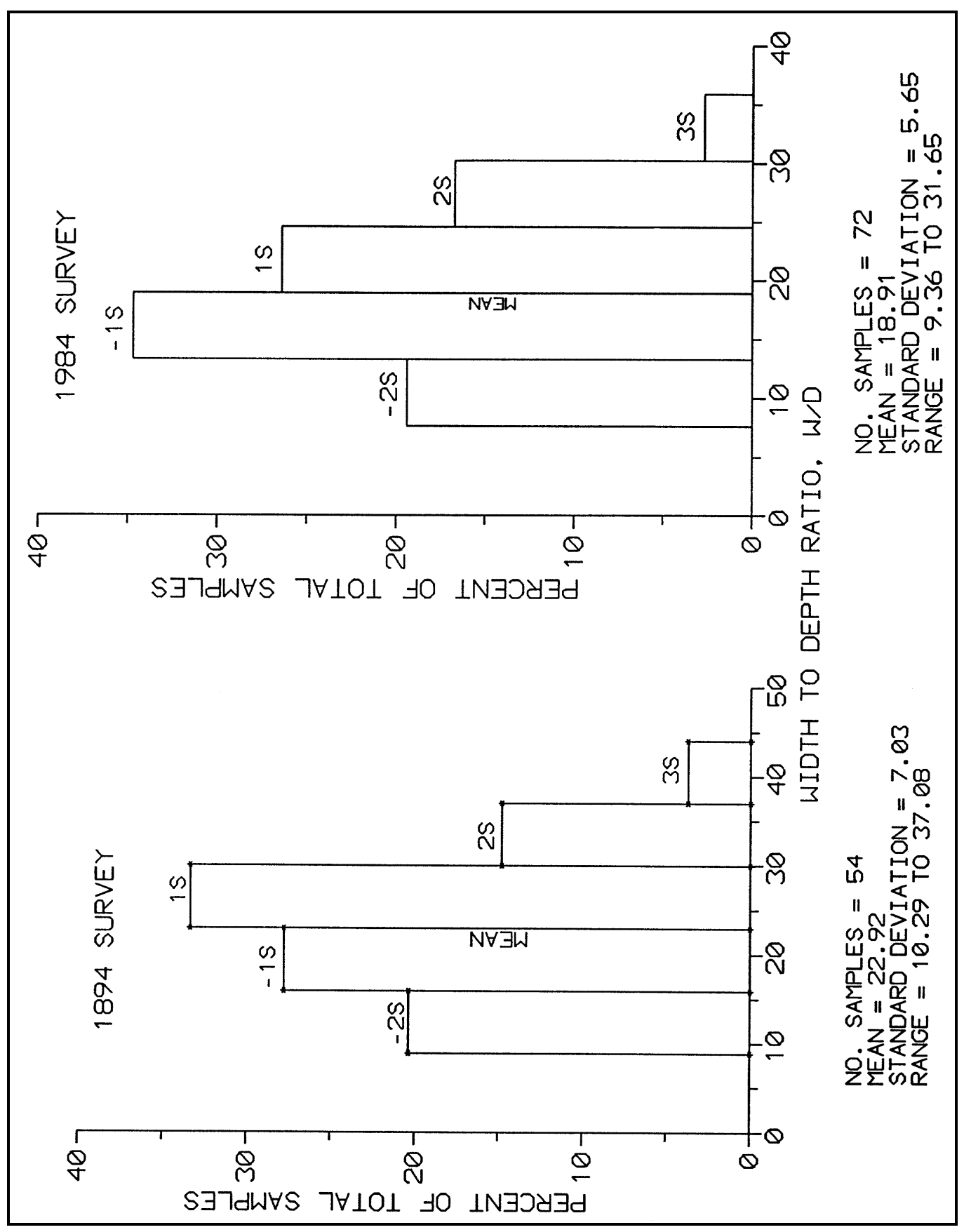

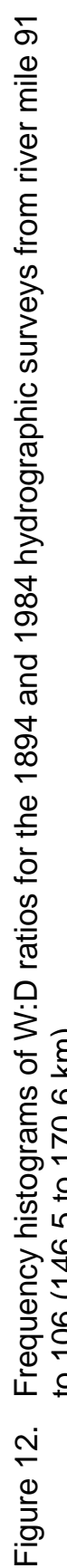




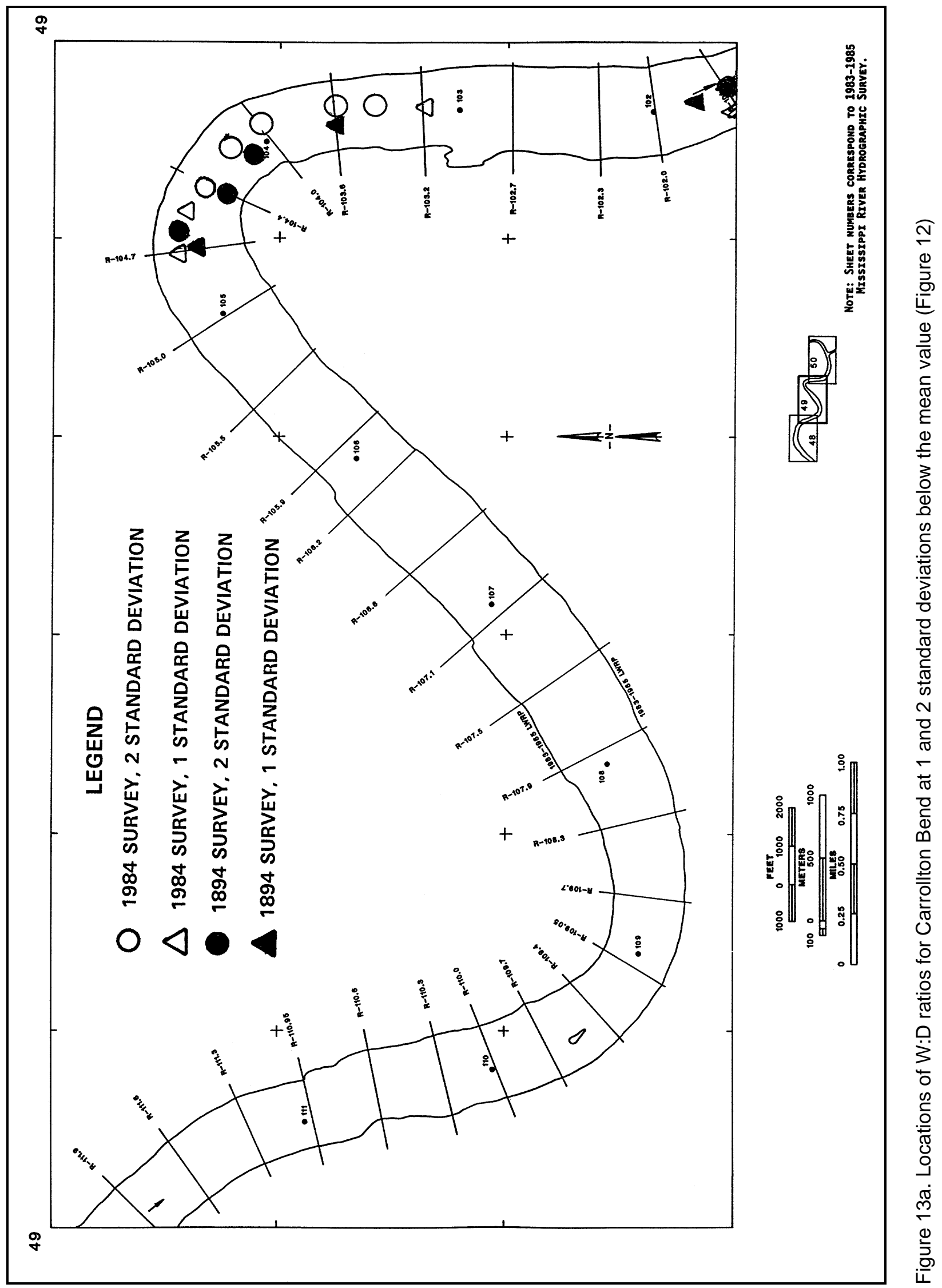




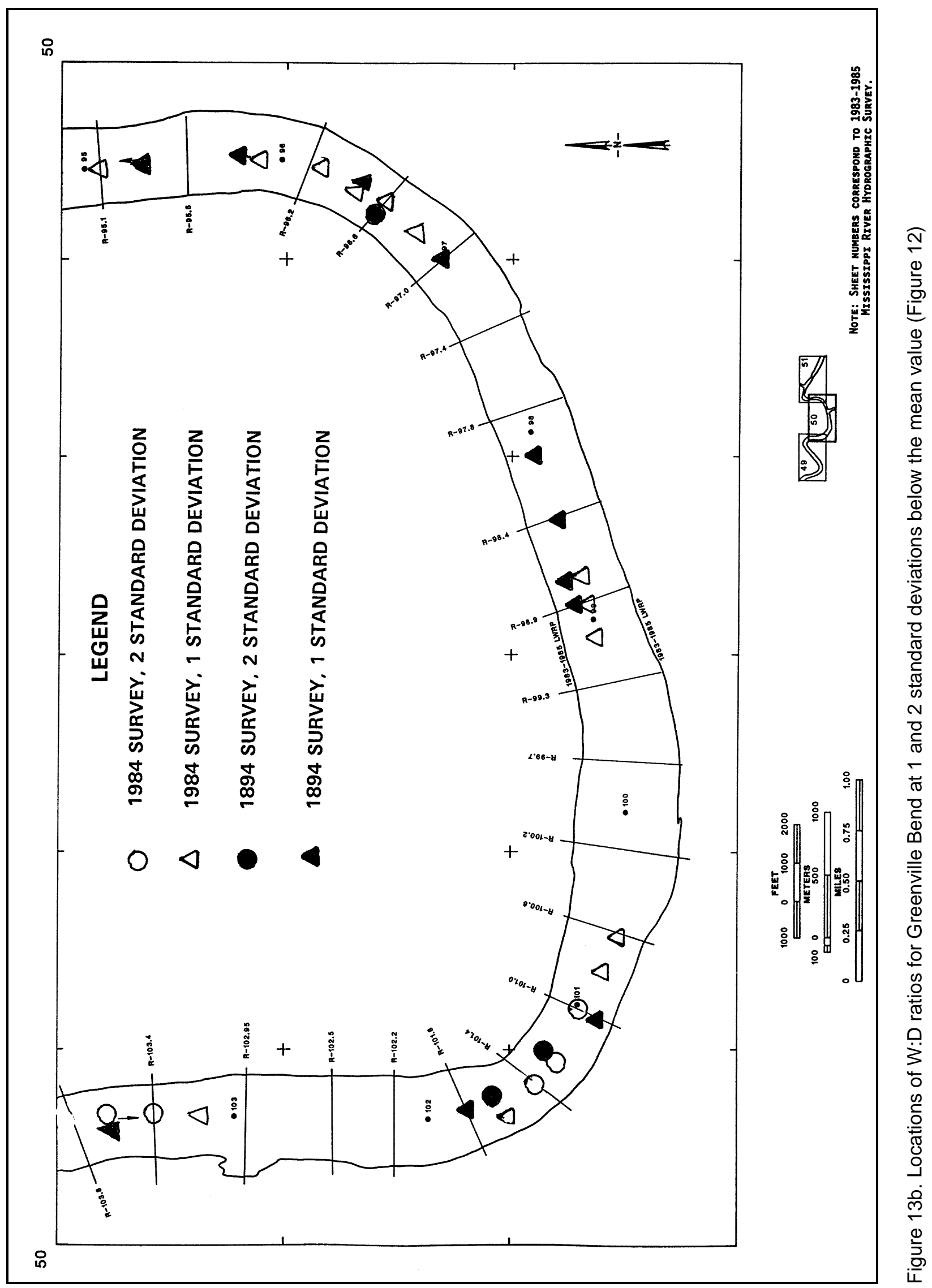




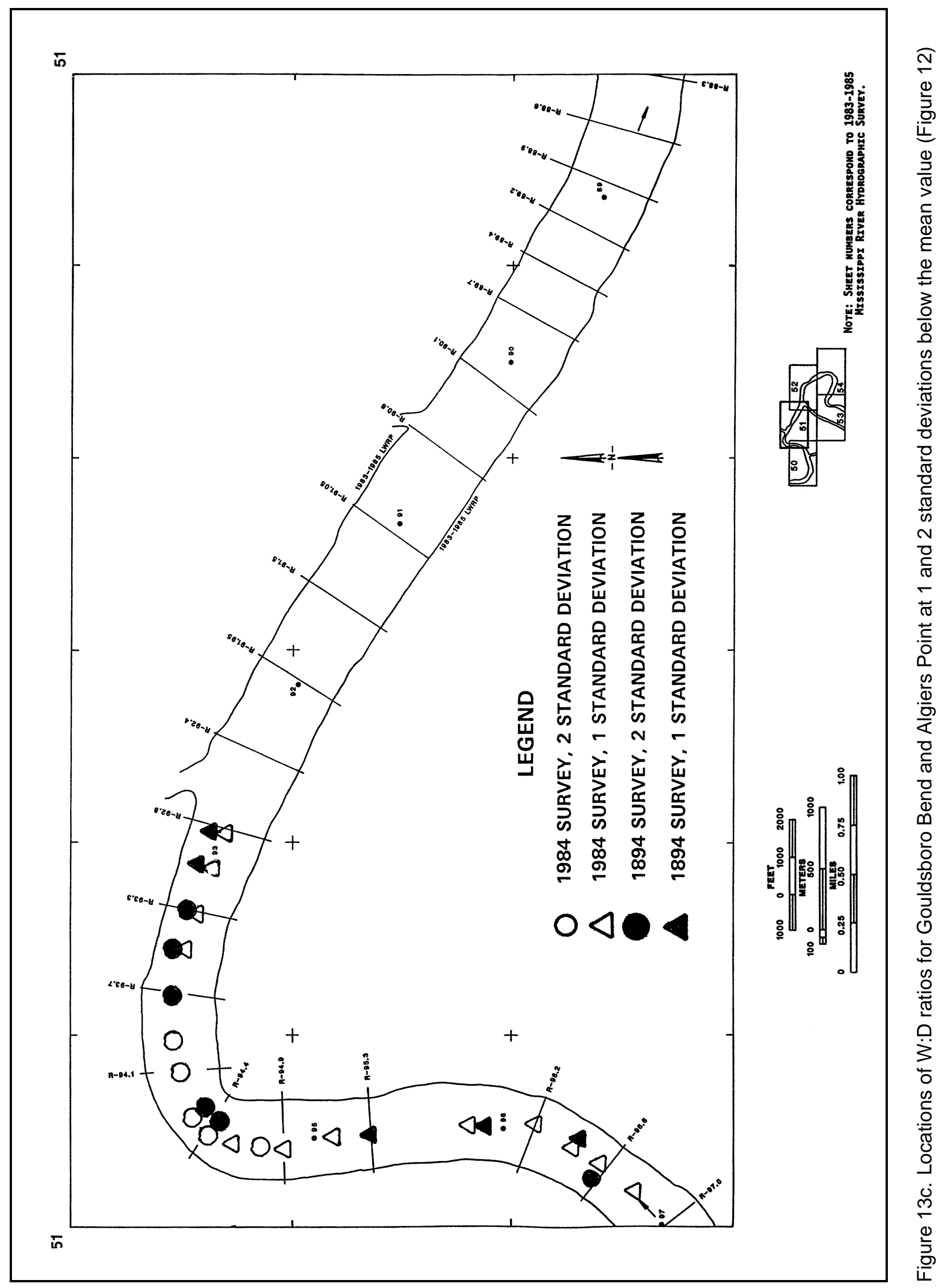


channel. Low W:D values correspond to the channel bendways as shown by the preceding figures. There has been some downstream migration of the scour pools at Carrollton and Greenville Bends. The scour pool at Gretna Bend has remained relatively stable, while at Algiers Point, the scour pool has slightly decreased in length and deepened according to the W:D ratios for the two surveys (Figure 13c). W:D ratios identified in Figures 13a through 13b are the deepest and narrowest river locations within the study reach. These locations should be regarded as potential problem areas.

As seen from the preceding figures, the Celotex failure site at river mile $100.25(161.33 \mathrm{~km})$ is not located in an area where low historic W:D ratios have occurred. There is no survey profile directly at the failure site. The nearest available survey locations or W:D ratios to the Celotex failure area are at river miles 100.2 and $100.3(161.2$ and $161.4 \mathrm{~km})$. At river mile $100.3(161.4 \mathrm{~km})$, $\mathrm{W}: \mathrm{D}$ ratios occur within the 2 nd and 1 st standard deviation (SD) above the mean for the 1894 and 1984 surveys, respectively (Figures 12a and 12b). There has been a historic shift of $\mathrm{W}: \mathrm{D}$ values from the 2 nd to the $1 \mathrm{st} \mathrm{SD}$, or to a deeper and more narrow channel during the period of record. At river mile 100.2 $(161.2 \mathrm{~km}), \mathrm{W}: \mathrm{D}$ ratios for both the 1894 and 1984 surveys occur at $2 \mathrm{SD}$ above the mean value. Based solely on W:D ratios, the Celotex site is not in an area where unstable river banks would be expected.

The next available W:D ratio upstream from the Celotex failure site is at river mile $100.6(161.9 \mathrm{~km})$. At this location, there has been a shift from the 1st SD above the mean to the 1st SD below the mean. The historic implication of the W:D data indicates that a deeper and/or narrower channel configuration has occurred within the Greenville Bend revetment reach in historic times.

As seen from Figure 13b, the Greenville scour pool has migrated downstream and possibly enlarged according to the low W:D ratios at this location. A similar trend occurs at Carrollton Bend (Figure 13a). At Gretna Bend, the scour pool has shifted upstream between river mile 98 and $99,(157.7$ and $159.3 \mathrm{~km})$ and remained nearly constant between river miles 96 and $97(154.5$ and $156.1 \mathrm{~km})$ (Figure 13b). The scour pool at Algiers Point (Figure 13c) has expanded upstream but has not generally moved downstream. Again, W:D data generally indicates that the frequency of locations with W:D ratios below the mean value has increased. Consequently, the general trend has been toward channel deepening with a corresponding reduction in channel width.

\section{Celotex Failure Reach}

\section{Procedure and profile locations}

Since this report is specifically directed toward the Celotex failure, selected hydrographic profiles were constructed at five locations (Figures 14a through 14e) within the failure area to identify historic trends that have occurred. Selection of the profile locations (Figure 14a) was based on the availability of survey locations from the different hydrographic surveys. In addition, a profile (R98.9, Figure 14b) was selected at random outside the failure zone to establish historic morphometric trends for the entire survey reach. As previously 


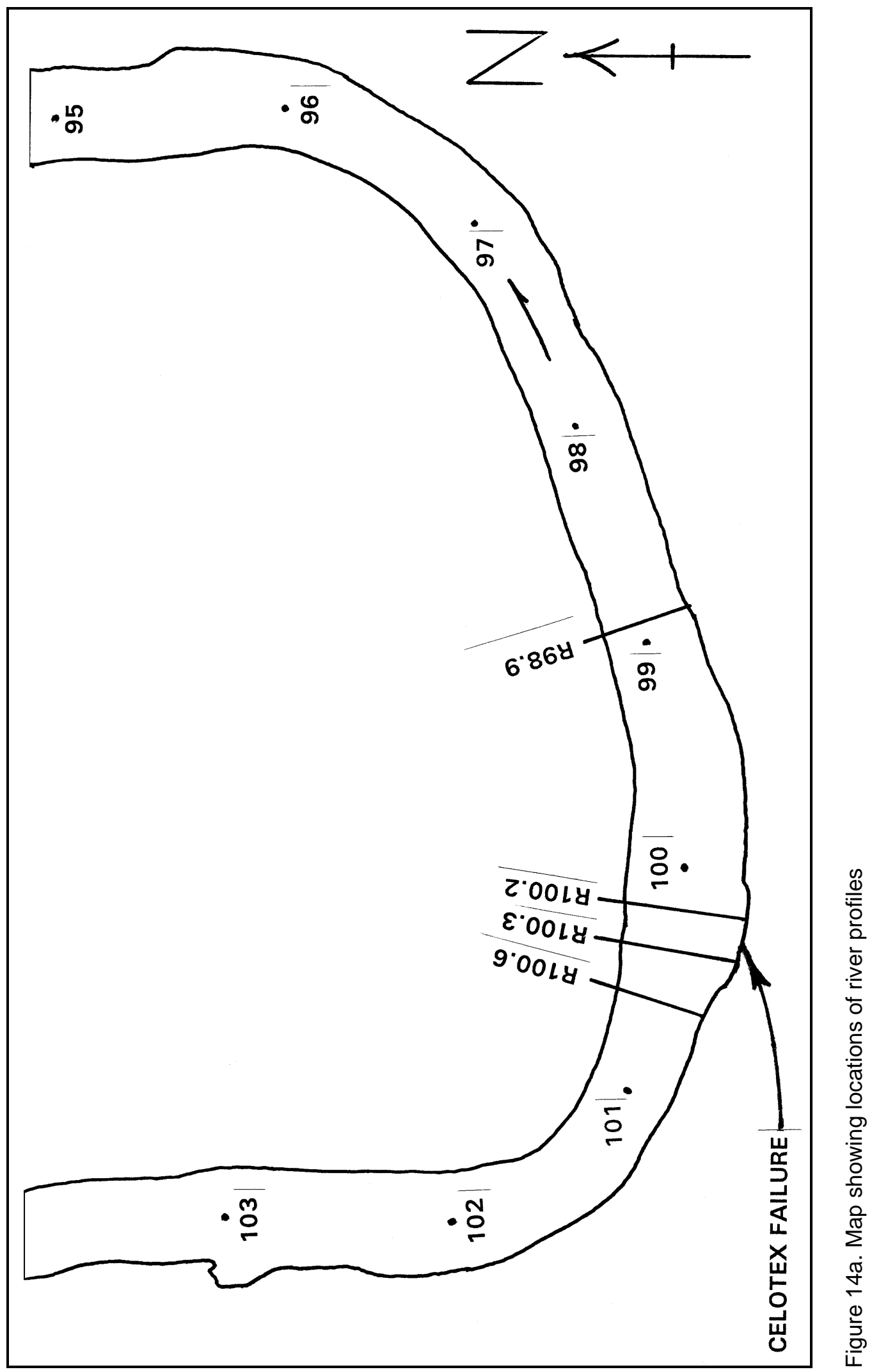




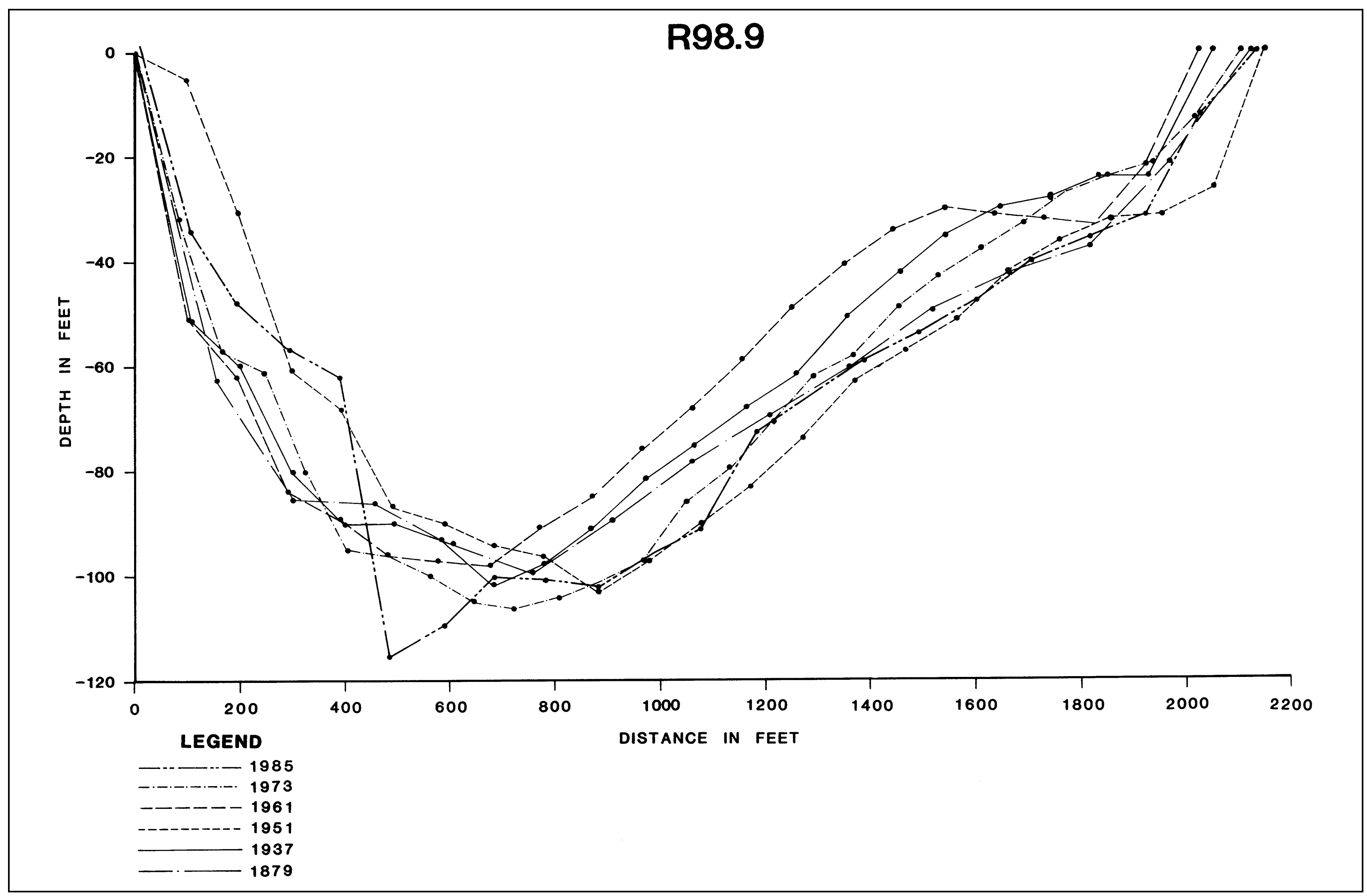

Figure 14b. Profile at R98.9 


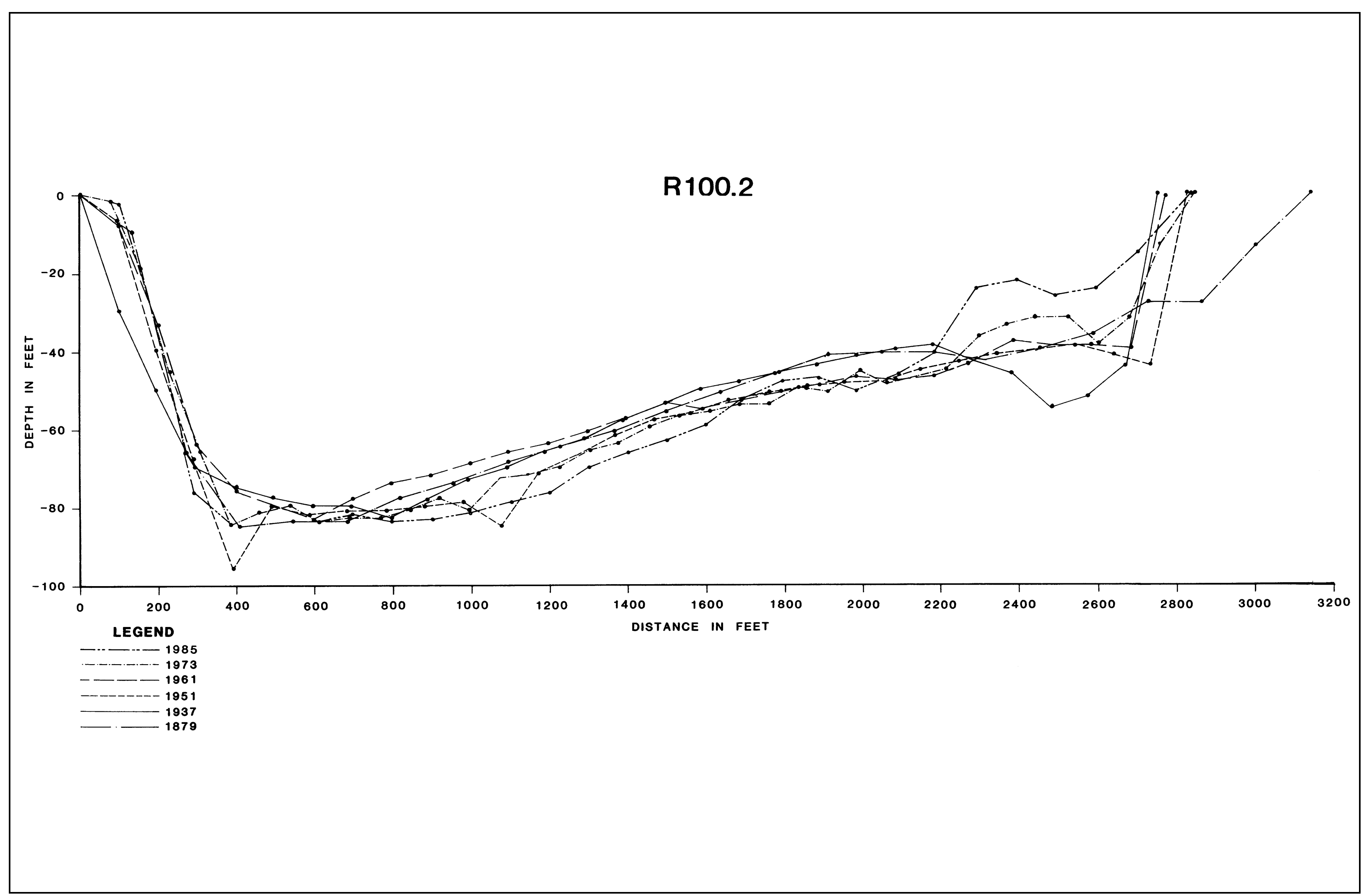

Figure 14c. Profile at R100.2 


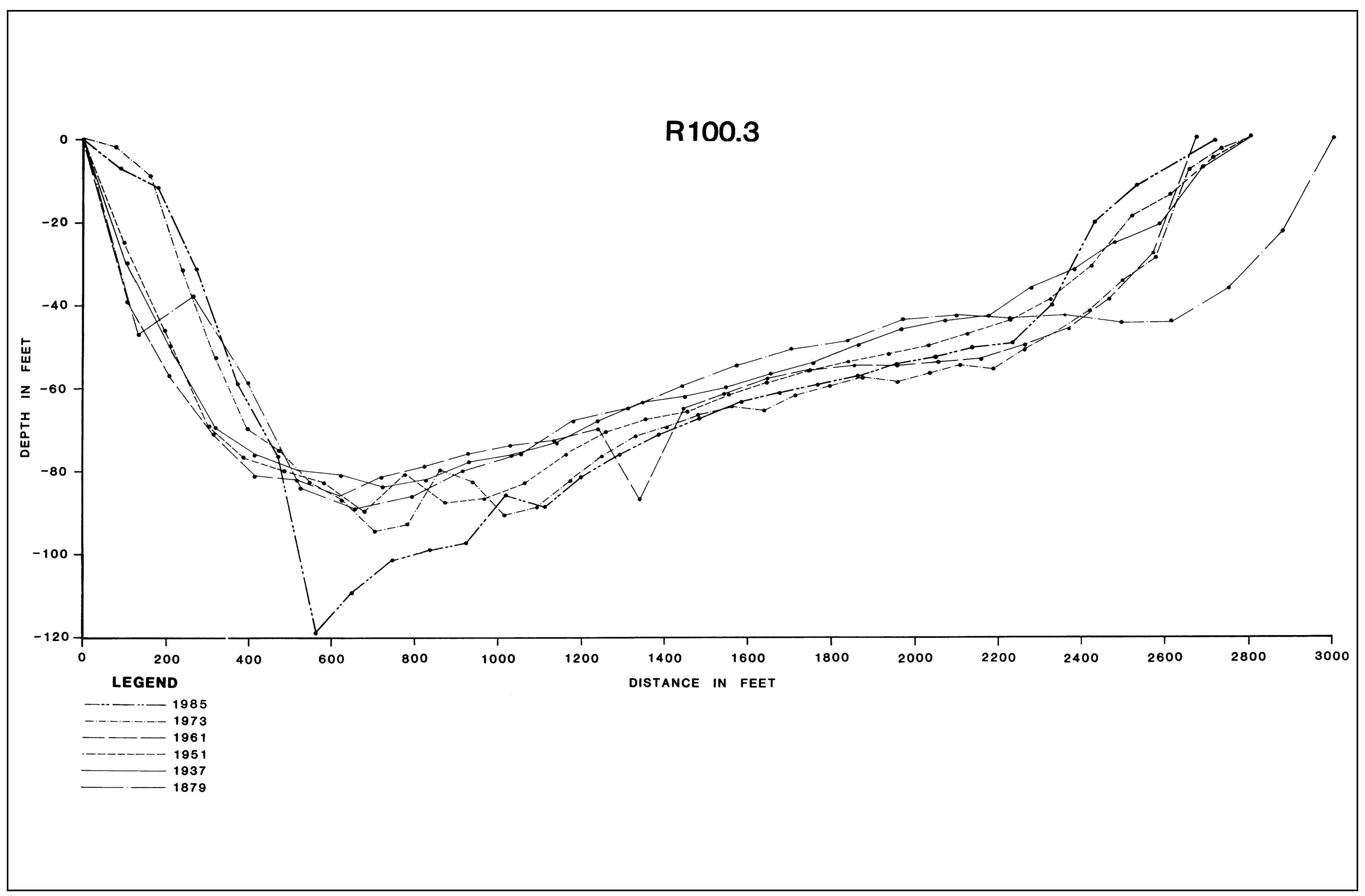

Figure 14d. Profile at R100.3 


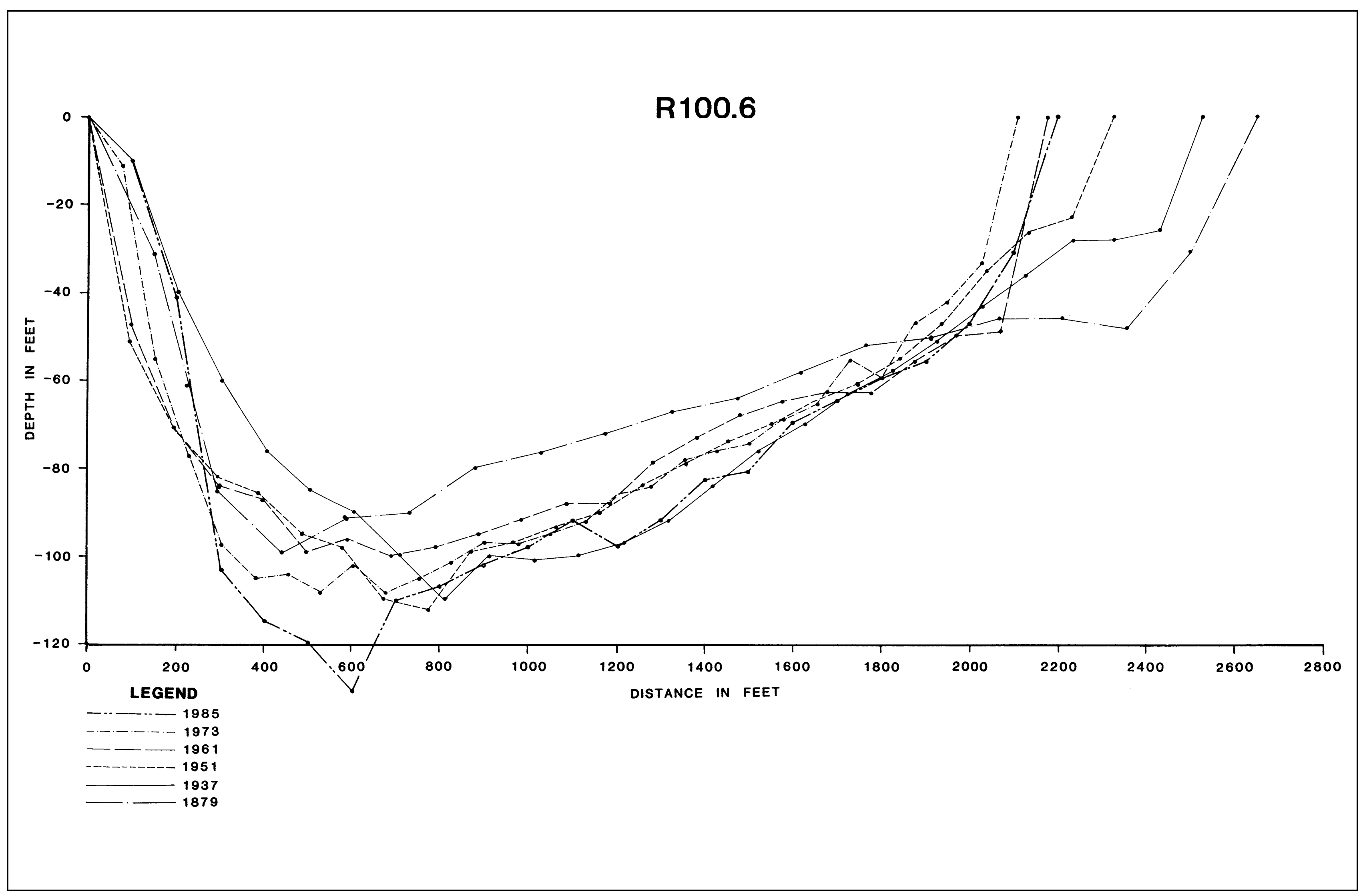

Figure 14e. Profile at R100.6 
indicated, there isn't a profile exactly at the failure location. Instead, profiles occur immediately upstream (i.e., R100.3) and downstream (i.e., R100.2) from the failure site as shown by Figure 14a.

River profiles were constructed such that the origin for each individual profile is the right bank and the view is upstream. Besides their historic spatial distribution to each other, area measurements were made for each profile to identify changes in channel cross sectional area through the failure reach. Channel area measurements were made by computer digitizing the individual profiles. Area measurements are presented in Table 4. Average cross-sectional area and comparison of different channel parameters are presented in Table 5.

\begin{tabular}{|c|c|c|c|c|}
\hline \multicolumn{5}{|c|}{$\begin{array}{l}\text { Table } 4 \\
\text { Area Measurements (in square feet) of Channel Profiles at } \\
\text { Selected River Ranges (Figures 14b through 14e) }\end{array}$} \\
\hline YEAR & R98.9 & R100.2 & R100.3 & R100.6 \\
\hline 1984 & 132,966 & 152,062 & 158,524 & 171,924 \\
\hline 1973 & 131,103 & 153,353 & 160,663 & 158,490 \\
\hline 1961 & 117,554 & 147,656 & 162,149 & 158,541 \\
\hline 1951 & 128,553 & 160,485 & 156,669 & 165,122 \\
\hline 1937 & 121,670 & 154,176 & 149,731 & 163,888 \\
\hline 1894 & 131,818 & 155,634 & 160,414 & 160,210 \\
\hline
\end{tabular}

\section{Table 5 \\ Comparison of Channel Area Measurements (in square feet) for Selected River Profiles (Figures 14b through 14e)}

\begin{tabular}{||l|l|l|l|l||}
\hline \hline Measurement & R98.9 & R100.2 & R100.3 & R100.6 \\
\hline \hline Average & 127,282 & 153,894 & 158,025 & 163,029 \\
\hline Max/Avg & 1.045 & 1.043 & 1.026 & 1.055 \\
\hline Min/Avg & 0.924 & 0.959 & 0.948 & 0.972 \\
\hline $1984 / \mathrm{Avg}$ & 1.045 & 0.988 & 1.003 & 1.055 \\
\hline $1894 / \mathrm{Avg}$ & 1.036 & 1.011 & 1.015 & 0.983 \\
\hline
\end{tabular}

\section{Discussion}

Examination of Table 4 shows channel area measurements by time periods for the selected river ranges. Area measurements represent the channel cross section based on the low-water reference plane or its equivalent depending on survey year (Table 1). Comparison of the channel areas shows a slight variability in the maximum and minimum values for each individual profile between survey periods. There are no extreme deviations between the maximum and minimum values as shown by Table 4 . Interestingly, the difference between the maximum and minimum area values isn't much, generally less than 8 percent for the three profiles surrounding the Celotex failure. Additionally, the maximum and minimum areas occur at different times rather than at any one particular 
survey year. The area values in Table 4 are generally alike for the profiles at the Celotex failure site. This fact is best shown by the average values in Table 5 for the profiles at the failure site. There is less than a 6 percent range in the average values.

Further downstream from the failure site, profile R98.9 is outside of a channel bendway; thus, the channel area is much less than the three upstream profiles. And, the different channel area values at this location vary more than the Celotex failure site. The range between the maximum and minimum values is approximately 12 percent for profile 98.9 .

Several other measures of channel variability are presented in Table 5. A ratio is presented for the maximum, minimum, the 1985 area, and the 1894 area as compared to the average area at each profile location. These different variability ratios reflect the change between survey periods and between adjacent profiles. Much of the bank migration data that have been presented to date involves the 1894 and the 1984 surveys. Recall that the basis for using these two survey periods is that there has not been much lateral migration through the study area over the short term. Thus, a longer-term comparison shows the maximum change that has occurred in the study area. Comparing the 1984 and 1894 area values, as well as their average ratios, indicates that almost no change in channel area has occurred in the study reach during historic time. From the area data it appears that flow conditions have been relatively constant in the study reach through historic time.

A point from the preceding section that is again supported by the selected river profiles in Figures 14b through 14e involves the relationship between channel width and depth. The 1984 river profiles are at or near their maximum depth with a corresponding decrease in channel width. Profile R100.3 (Figure 14d) best illustrates this relationship. At this location, channel depths have substantially increased while channel width has decreased. Channel depths during the 1984 survey increased nearly $40 \mathrm{ft}(12.2 \mathrm{~m})$ as compared to the 1884 survey, and the corresponding reduction in channel width was approximately $300 \mathrm{ft}(91.4 \mathrm{~m})$.

In summary, W:D ratios are a measure of channel morphology and can be meaningful as an indicator for identifying unstable river bank locations. However, additional data are necessary to further evaluate the potential for unstable bank locations. Equally important are geologic and historic bank migration data as sources to verify potential locations for bank instability below Baton Rouge, LA. 


\section{The Celotex Levee Failure}

\section{Introduction}

Some of the information and figures presented in this section of the report were derived from the LMN internal report, "Mississippi River Levees, Item M-100.4-R, Celotex Levee and Batture Restoration, Final Report, May 1987," (USAED, New Orleans 1986). General information and figures derived from this report and presented herein will not be continuously cited in the paragraphs that follow. Additionally, the terms "bank failure, flow failure, or flow slide" are often used interchangeably throughout this report. These terms are considered to be equivalent. Usage of these terms as well as a history of their usage in earlier potamology studies is described further by Torrey, Dunbar, and Peterson (1988).

\section{Failure History and Repair Chronology}

Around 2 o'clock on the morning of 30 July 1985, a tugboat operator reported to the LMN Operations Division a riverbank failure at river mile 100.25 $(161.33 \mathrm{~km})$. The failure occurred on the west bank (right descending) of the Mississippi River, in the Jefferson Levee District, approximately 0.5 miles $(0.8 \mathrm{~km})$ south of Westwego, LA, and within the Greenville Bend revetment reach (Figure 15). The failure progressed landward and involved the levee crown by 6 a.m. An aerial photograph showing the failure location is presented in Figure 16. Landward of the failure area is the industrial complex of the Celotex Corporation as shown by Figures 15 and 16. Although it was the lowwater season and the levee was not breached by the failure, a major concern by LMN was the possibility of a hurricane from the Gulf of Mexico since it was the hurricane season and elevated water levels could result in breaching of the failed levee.

By midmorning 30 July 1985, LMN had responded to the failure with a fathometer survey in the failure reach and began geotechnical drilling and soil sampling behind the failure area to investigate a levee setback and new alignment. Drilling in the setback area encountered a hard material at a depth of only $3 \mathrm{ft}(1 \mathrm{~m})$ below the surface. The hard material was asbestos with a thickness of about $3.5 \mathrm{ft}(1.1 \mathrm{~m})$. Drilling was immediately halted until crew members from the drilling operation could be provided with proper protective equipment against asbestos hazards. In addition, within the failure area itself, water borne 


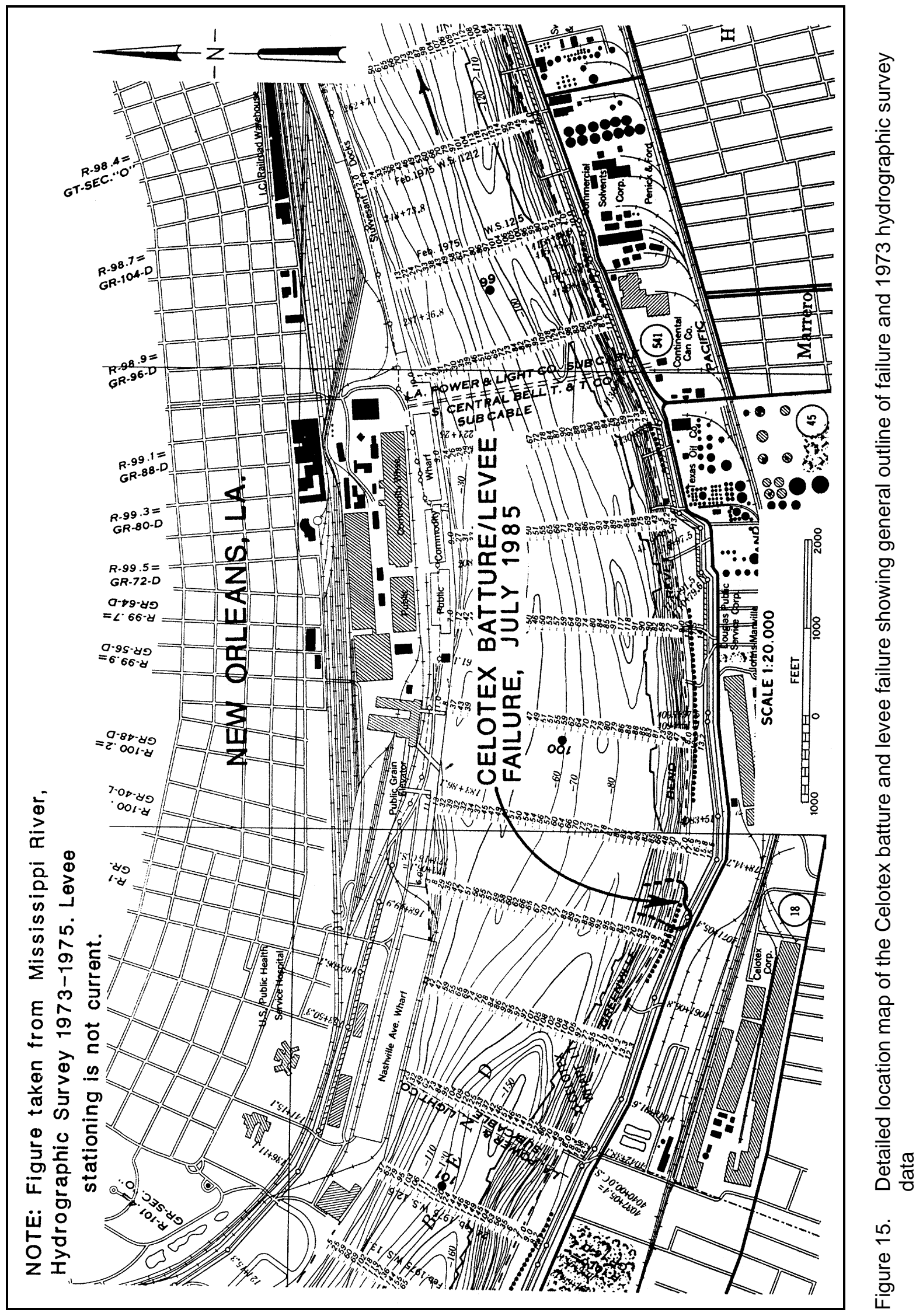




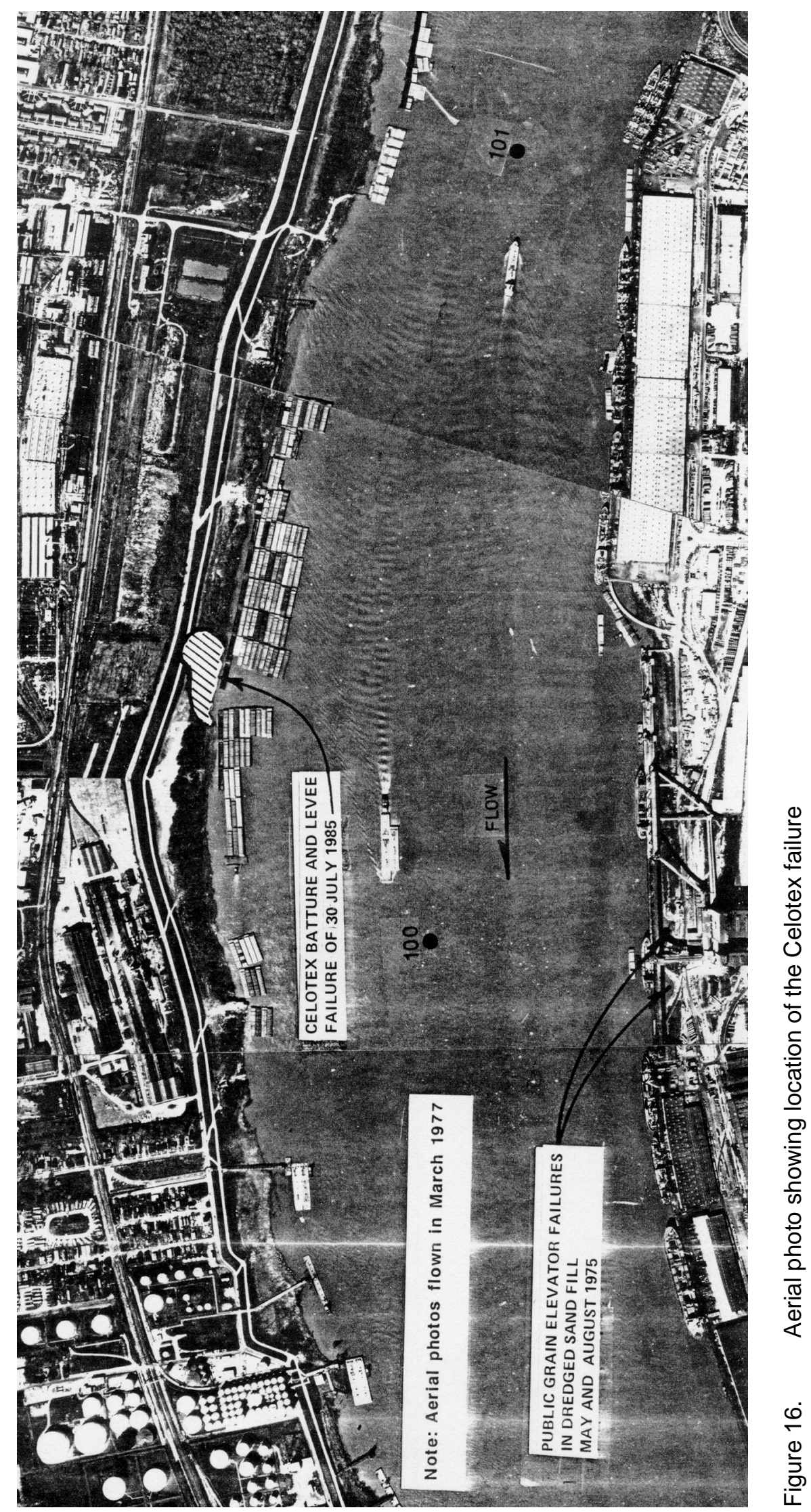


drilling operations were conducted to determine if any overburden material remained within the failure scar.

The presence of a hazardous waste dump in the setback area caused LMVD to instruct LMN to investigate alternative repair designs for restoring the batture and rebuilding the levee to avoid a setback. Alternatives for restoring the batture and levee in place were made by 23 August 1985. Final plans and specifications were prepared and approved, and the contract was awarded on 30 August 1985. Repairs were finally completed on 28 November 1985, 129 days after the first reporting of the failure.

Repairs involved innovative and cost saving restoration techniques. The construction sequence involved the following tasks (Figure 17):

a. The failed batture was rebuilt with shell to el $3.0 \mathrm{ft}(0.91 \mathrm{~m})$ NGVD. Approximately $272,000 \mathrm{cu}$ yd $(208,000 \mathrm{cu} \mathrm{m})$ of shell was placed in 60 to $70 \mathrm{ft}$ (18.3 to $21.3 \mathrm{~m})$ of water.

$b$. The remaining portion of the failed levee was reshaped to receive new fill.

c. Filter cloth was placed as a separator between new levee berm fill and the shell backfill. Prior to placement of the filter cloth, the shell batture was raised to el $5.0 \mathrm{ft}(1.52 \mathrm{~m}) \mathrm{NGVD}$ in the area of the new levee fill to avoid a rising river stage.

d. Construction of the new levee berm to el $7.5 \mathrm{ft}$ (2.29 m) NGVD with semicompacted fill to keep the work ahead of a rising river.

$e$. The shell batture/bank was armored with a 5-ft (1.5-m) thick layer of rip-rap stone.

f. After completion of the new levee and buttress berm, the slope of the buttress berm was armored with an 18-in.- (45.7-cm-) thick layer of stone.

g. The riverside levee slope was protected by placing sand-cement filled bags.

$h$. The armored shell riverbank was revetted with articulated concrete mattress.

\section{Dimensions and General Character of the Celotex Failure}

A contour map is presented in Figure 18 showing the general dimensions of the failure area and the locations of the survey range lines referenced in the text that follows. The contour map of the failure area is based on fathometer surveys and borings drilled within and adjacent to the failure reach. A cross section through the failure or flow slide area is presented in Figure 19 showing boring data and fathometer profiles from selected time periods (see Figure 18 for profile locations). In addition, three-dimensional (3-D) computer images of the failure 


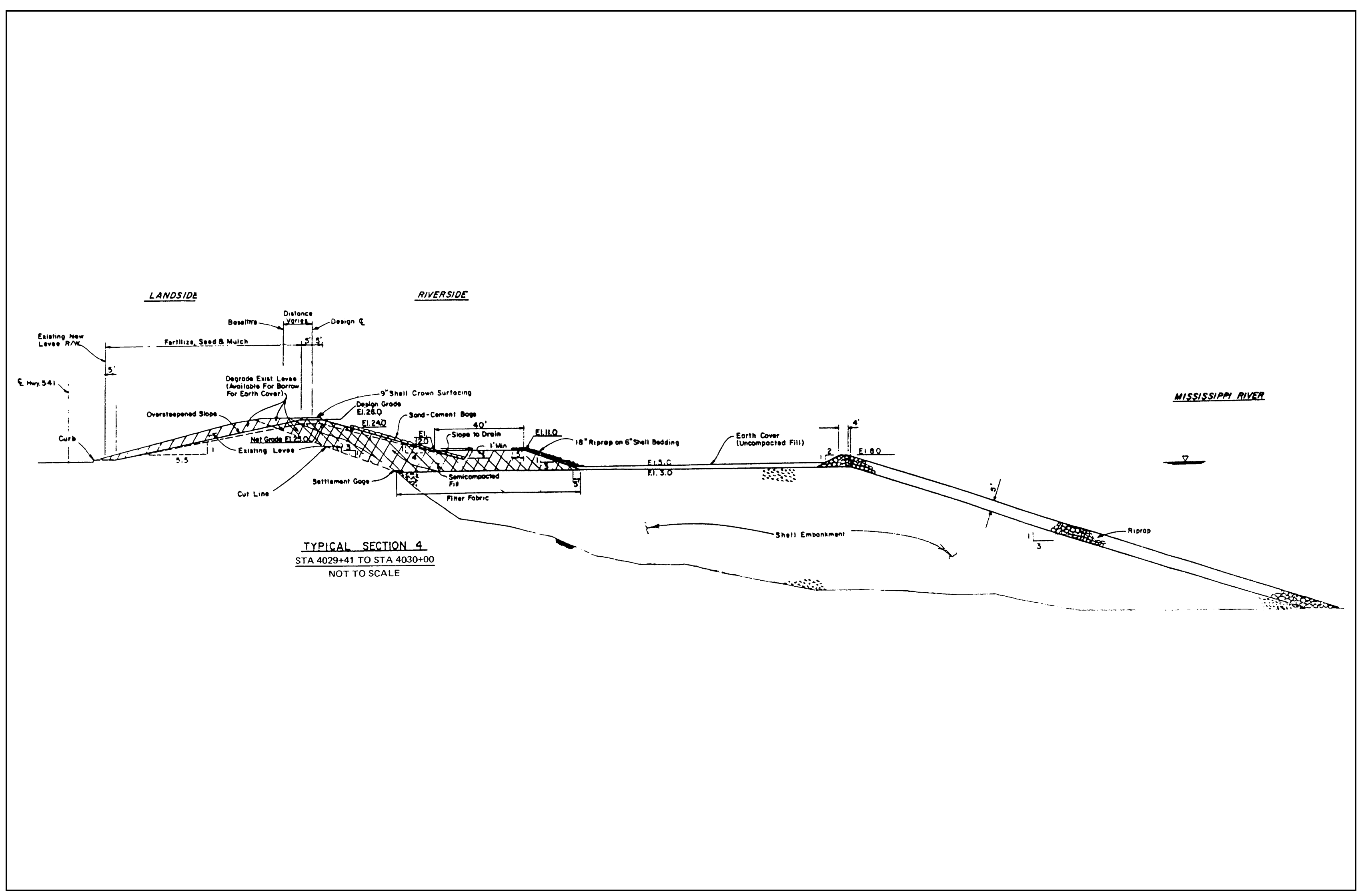

Figure 17. Batture and levee restoration diagram of the Celotex failure 


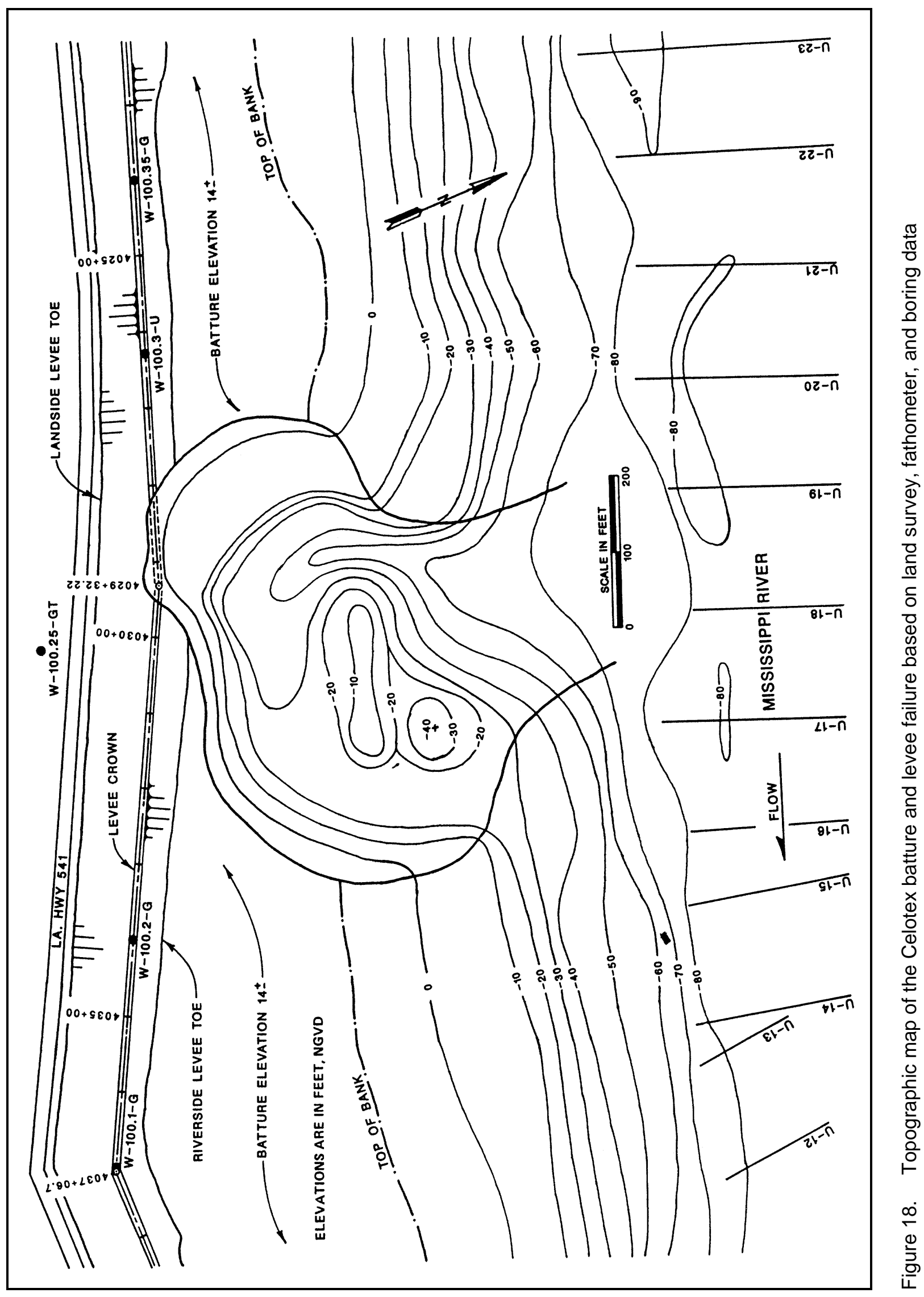


are shown in Figures 20 and 21. The plan view, sections, and 3-D images of the failure reveal the bottleneck shape and relatively flat bottom slopes transverse to the bank line which are typical of a flow slide. At its widest point, the failure is approximately $600 \mathrm{ft}(182.9 \mathrm{~m})$ in length and the failure plane extends to approximately $-70 \mathrm{ft}(-21.3 \mathrm{~m}) \mathrm{NGVD}$ as shown by Figure 19.

A line of borings drilled after the failure between Greenville Bend revetment ranges U-18 and U-19 (see Figure 18 for revetment locations) indicates that overburden material was present in the scar. These borings were fortunate in their placement and revealed some other important aspects of the failure's appearance as well as suggesting a sequence of events to be addressed in the paragraphs that follow.

Information presented in the preceding figures emphasizes the need for detailed surveys of future failure sites so that quality contour views can be constructed. Survey range lines should be no more than $50 \mathrm{ft}(15.2 \mathrm{~m})$ apart and extend to the thalweg. Portions of failures above water should also be surveyed in detail after the fashion necessitated by the repair methods for Celotex. Surveys should be initiated as close to the failure event as practical. For research purposes, surveys are needed even if the failure is only to be graded and revetted or if the failure is in unrevetted bank. Such quality data are now especially important to help eliminate any doubts about previous predictions of potential batture loss (Torrey 1988).

\section{Discussion of the Failure}

The Celotex failure added a new dimension to the problem of flow slides below Baton Rouge for the simple reason that it occurred during the low-water season. In the past, flow slides have been associated with high water, in point bar deposits, and at a position on the upstream end of the inside of a bendway. Reasons for the Celotex failure during low water are not known. Is something occurring in the scour pools during low water that is not perceived?

Celotex is not the only low-water flow failure of which the authors are aware. During the summer of 1980, a flow slide developed at the downstream end of the Montz revetment on the left descending bank at approximately river mile 129.9 $(209.0 \mathrm{~km})$. However, it has long been known that severe scour conditions are produced directly at the downstream end of revetment mattress. In fact, this knowledge has led to careful consideration of the downstream extent of placement of revetment mattress below Baton Rouge to ensure that such scour does not trigger a flow slide which might not ordinarily occur and threaten the levee. The Celotex failure was clearly not of this nature as it was located within a revetted reach and not at the end of one. This location was previously classified as susceptible to flow failures (Torrey 1988).

Boring data and geological mapping indicate that the failure area exhibits the particularly dangerous soil stratigraphy of thin overburden (i.e., topstratum) over a thick deposit of fine sands and silty sands (i.e., substratum) as shown by Figure 22 (also see Figure 5c). Geological mapping in Figure 22 (and 5c) shows the failure is situated in point bar deposits associated with an early St. Bernard 


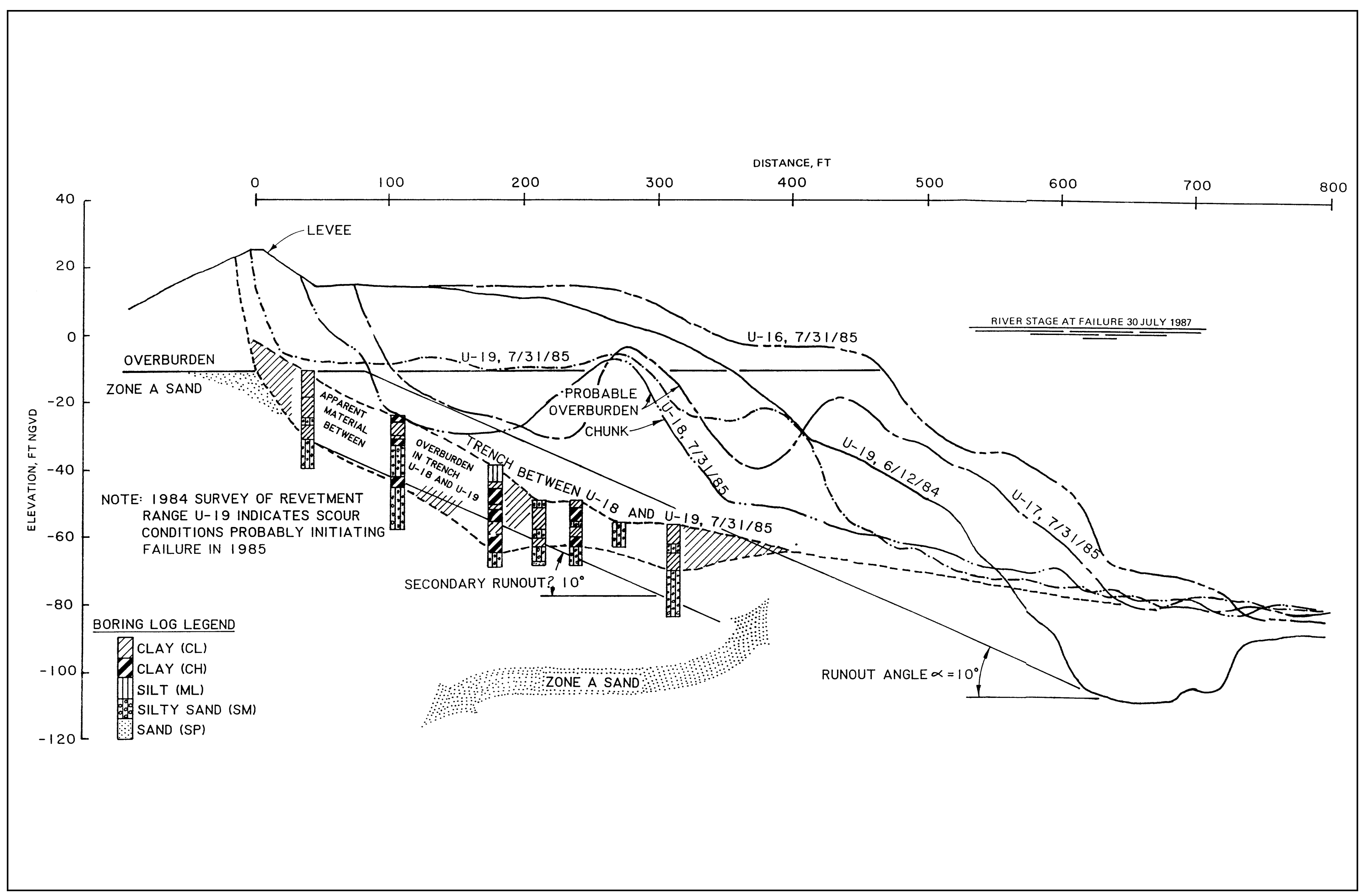

Figure 19. Cross sections of the Celotex failure showing boring and profile data from selected time periods 


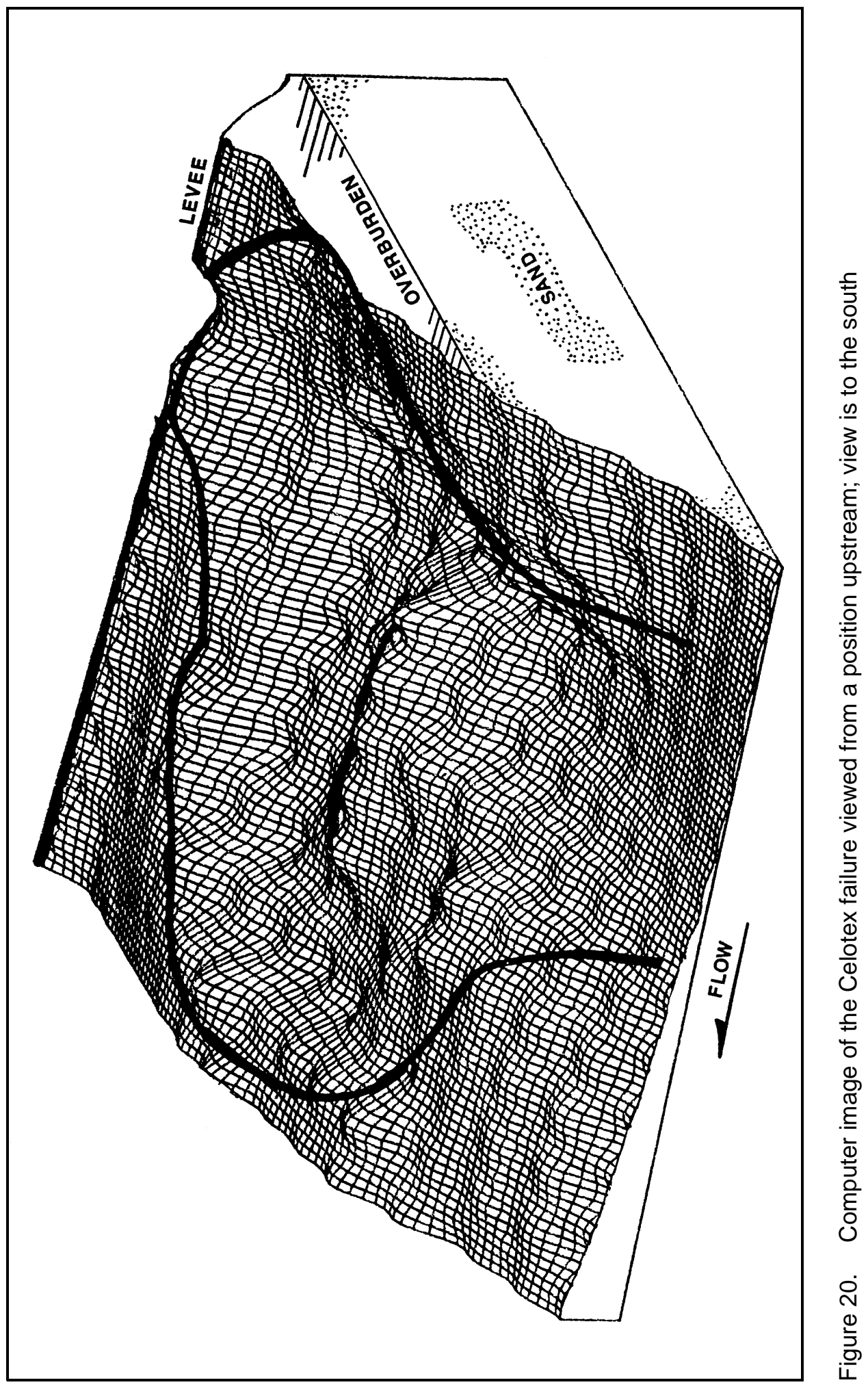




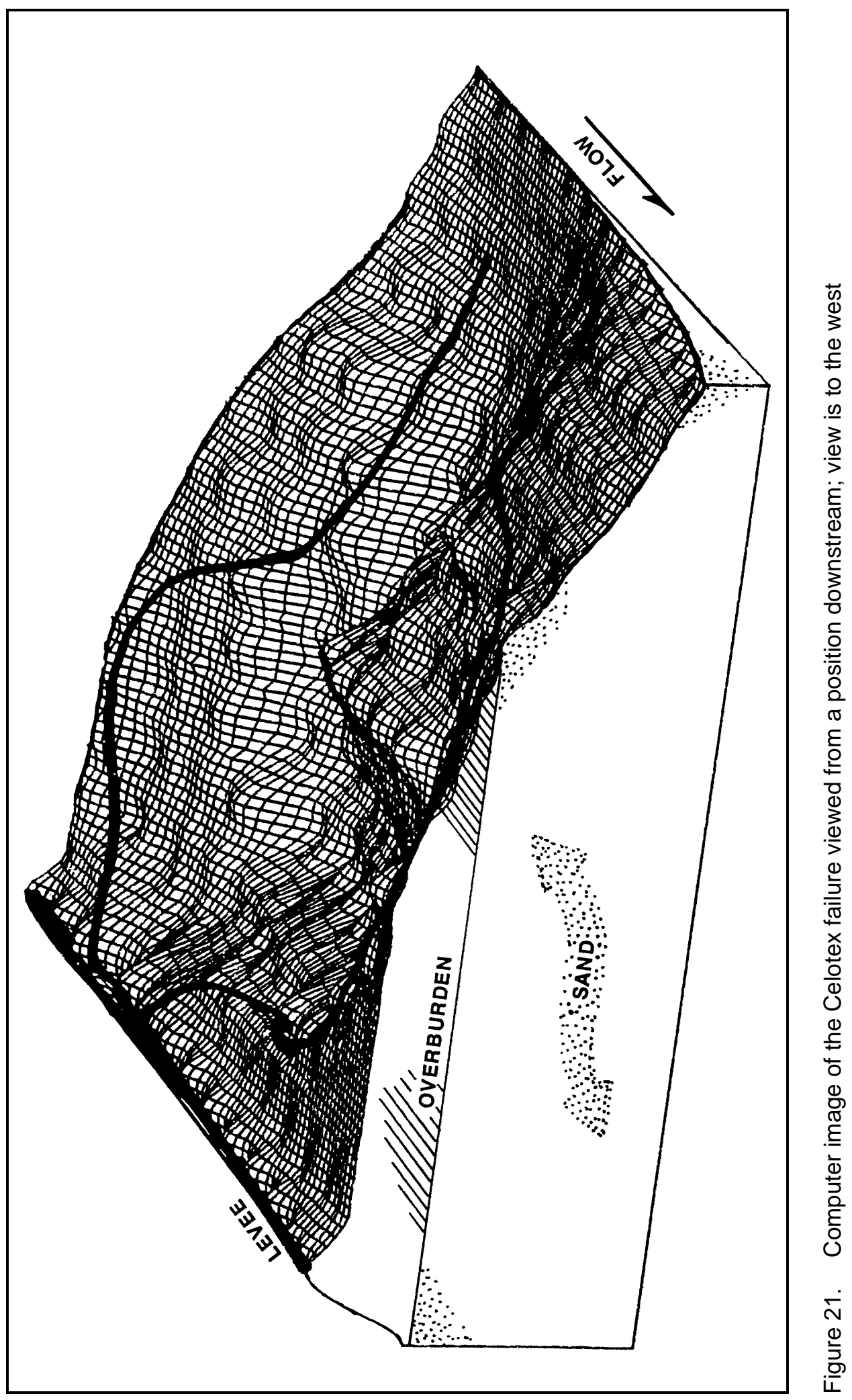




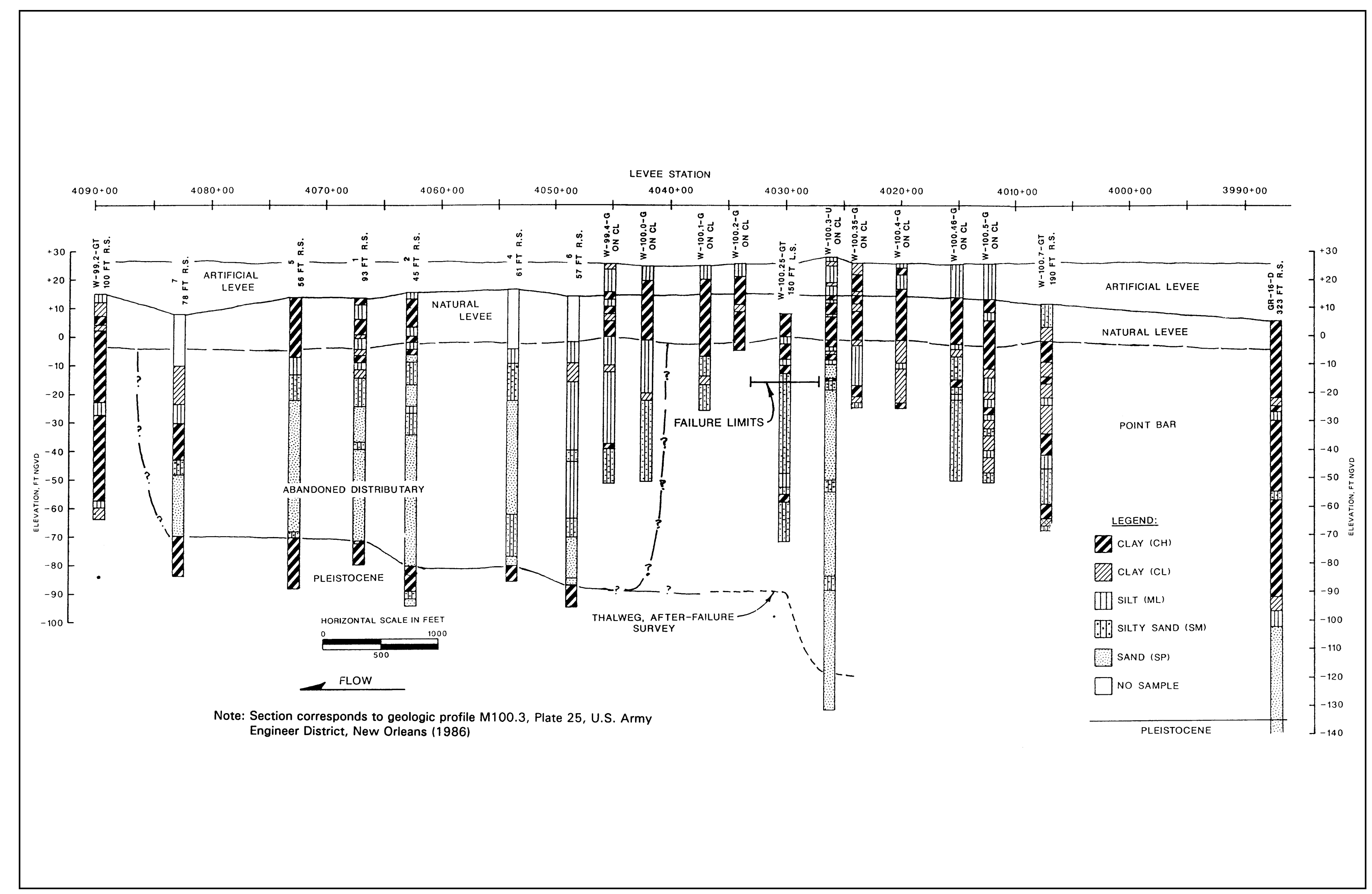

Figure 22. Soil profile along the bank reach containing the Celotex failure 
abandoned distributary course (see Figures 3 and 5c), rather than in the actual abandoned distributary channel as previously reported (USAED, New Orleans 1986; Torrey 1988). Late 1880's topographic data (U.S. Army Corps of Engineers 1975) and regional geologic mapping from the greater New Orleans area (Dunbar et al. 1994) indicate the abandoned distributary channel is probably east of the failure area. However, the distinction between the two depositional environments is academic since there is not a measurable difference in soil types between these two environments (Kolb 1962). Both environments are generally characterized by thin topstratum or "overburden" and are both underlain by thick sandy substratum sands.

An important consideration in evaluating and understanding the Celotex failure is the Mississippi River stage prior to the failure. A stage hydrograph for the Carrollton gage located about 2.5 river miles $(4.0 \mathrm{~km})$ upstream of the failure location is shown in Figure 23. On the day of the failure (i.e., 30 July 1985), the river had reached its lowest level during the year at about elevation $2.0 \mathrm{ft}(0.6 \mathrm{~m})$ NGVD. Immediately following the failure, the river began to rise and continued to rise during the repair operations (Figure 23). The river was falling prior to the failure, beginning in late June at an average rate of only about $0.1 \mathrm{ft}(3.0 \mathrm{~cm})$ per day. The stage hydrograph in Figure 23 shows that the general trend since mid March was a steady decline from its peak at about el $16 \mathrm{ft}$ (4.9 m) NGVD.

Years ago the LMV Potamology Investigations studies evaluated seepage gradients in sands and silty sands resulting from such rates of falling stage. These earlier studies dismissed the role of rapidly falling river stages as causing instability of Mississippi Riverbanks (Clough 1966) or triggering flow failures (USACE 1950). The Clough (1966) report provided field piezometer installation data which showed that seepage gradients developing in sandy riverbanks during rapid fall in stage are not sufficient to induce mass bank failure or even significant seepage erosion.

At the time of the failure, the most recent hydrographic presurvey of the riverbank reach involving the Celotex failure site was made in June 1984. Survey profiles for various revetment ranges within and adjacent to the failure area are shown in Figure 19 (see Figure 18 for survey locations). Evident from revetment range U-19 (Figure 19) is the presence of a significant scour trench at the toe of the bank slope. The surrounding sections indicate that the trench ended less than $200 \mathrm{ft}(61 \mathrm{~m})$ downstream before reaching revetment range U-18. It is possible to track the trench upstream in the 1984 survey into the "permanent," deeper scour pool situated in Greenville Bend. Factually, it is conjecture that the scour trench existed at revetment range U-19 on the day of failure. However, on the strength of all the evidence to date regarding the triggering of flow failures, it is believed that the trench was present, that severe scour produced an "oversteepened" slope in the sands, and instigated the failure.

After failure, evidence of the trench is not present until a point about $700 \mathrm{ft}$ (213.4 m) upstream of range U-19 (i.e., at revetment range U-24). A rough estimate of the volume necessary to fill the scour trench yields approximately $150,000 \mathrm{cu}$ yd $(114,684 \mathrm{cu} \mathrm{m})$ of material. This estimate is based on 1984 survey data, and assumes a trench measuring approximately $700 \mathrm{ft}(213.4 \mathrm{~m})$ in length and beginning below el $-80 \mathrm{ft}(-24.4 \mathrm{~m})$ NGVD. Since the failure volume approached $300,000 \mathrm{cu}$ yd $(229,369 \mathrm{cu} \mathrm{m})$, it is feasible that failure debris had 


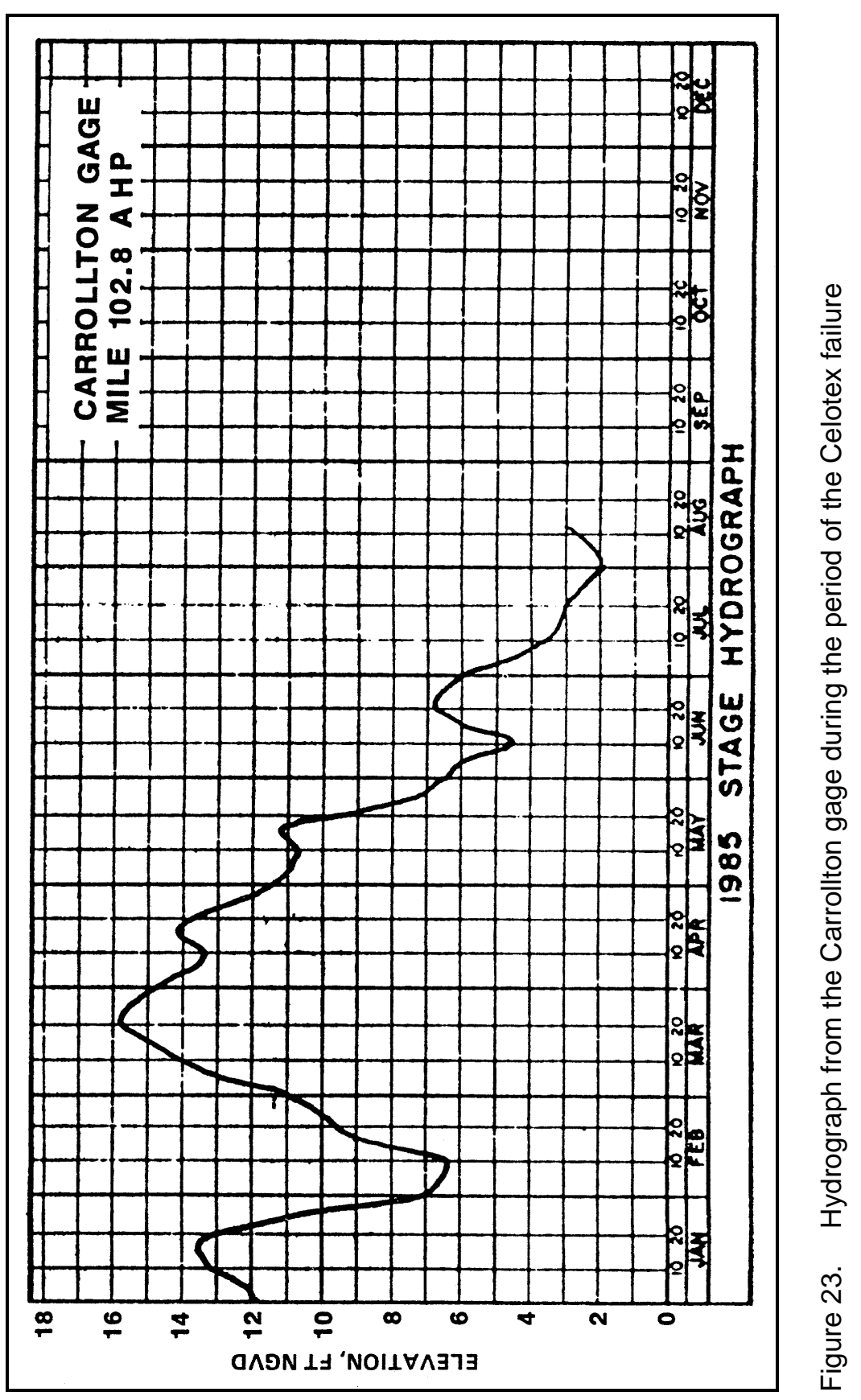


such mass and momentum that it filled the trench in the upstream direction against the low-flow current of the river.

Additional evidence that the failure was initiated at about revetment range U-19 is seen from Figure 18 where the typical narrow riverward neck is directed at that range. The orientation of the failure in plan view in Figure 18 also implies an outflow of debris in a slightly upstream direction. On 10 November 1985 , immediately before completion of repair of the batture and levee, a side-scanning sonar survey was run "looking" at the subaqueous portion of the riverbank at the failure site (Figure 24). The survey image shows the upstream outflow of failure debris and revealed the presence of two sunken barges lying on the slope of the bank on either side of the failure neck. There is no way to know if these barges played a role in the failure or how long these barges have been present at this location.

The only eyewitness account to the failure was the tugboat operator who initially alerted the LMN Operations Division. As understood by the authors, the tugboat operator stated that the bank went all at once. Considering that it was during darkness, it was possible that his attention (and lights of his boat) was not directed to the bank until significant mass moved, sound, and water disturbance alerted him of the failure. He did not apparently remain at the site to observe closely the events that followed the initial sighting. His account leaves little to go on. It is known, as stated previously, that batture loss continued up to about 6 a.m.

In studying the plan view and cross section in Figures 18 and 19, respectively, a possible sequence of events is speculated. From the plan view in Figure 18, the failure has the appearance of dual lobes. The main body or downstream portion of the failure is the more symmetrical and represents a flow slide. The landward or upstream portion represents the involvement of the levee section and has more of the U-shape of a typical shear failure. Consequently, a line of borings was logically drilled riverward from about the center of the levee slide (i.e., between revetment ranges U-18 and U-19) to investigate for the presence of overburden material remaining in the failure scar. These borings, coupled with the fathometer surveys of ranges U-18 and U-19, indicate that a narrow "trench" considerably deeper than the remainder of the failure existed along the line of borings. It would appear likely that the overburden material that was encountered lay only in the "trench" as indicated in the section in Figure 19.

Other evidence of probable overburden material remaining in the scar is shown by the topographic high in Figure 18 and the mound in Figure 19 between revetment ranges $\mathrm{U}-17$ and $\mathrm{U}-18$. This topographic high may represent a top stratum chunk which broke away but was not transported down slope into the river. At survey range U-17 (see both Figures 18 and 19), there is a "pit" or topographic low on the riverward side of the topographic high or mound which is in conformance with the general "bowl" shape of the failure. The computer images in Figures 20 and 21 support and better show the topographic features within the failure zone.

It is feasible that at some point during the progress of the main failure, which was initiated in the scour trench at about range U-19, a secondary event occurred within the main failure and landward of the initial trigger event. This latter 


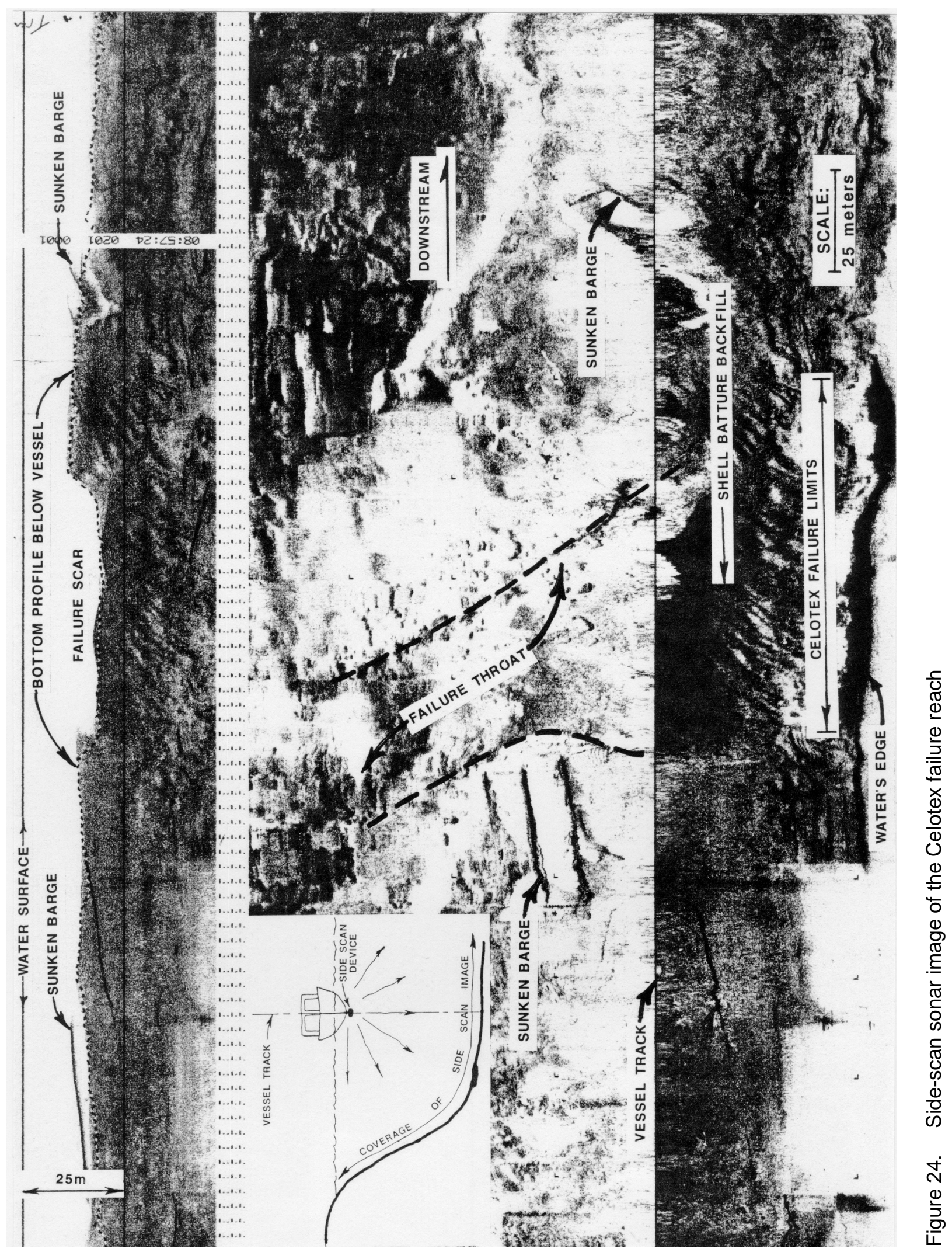


event triggered a secondary "runout" of sands which is evidenced by the trench between ranges U-18 and U-19 (Figure 18). The secondary flow produced instability in the top stratum and levee. The instability resulted in a shear failure and caused the movement of debris into the trench where it was encountered by the exploratory borings. The limited topographic data appears to support the hypothesis of a secondary "runout," followed by a mass shear slide of the levee to the basement elevation. The secondary lobe of the failure was at the overburden/sand contact near el $10 \mathrm{ft}$ (3.0 m) NGVD (Figure 19).

\section{Historic Ramifications of the Celotex Failure}

Historic bank lines from the Greenville Bend revetment reach are shown in Figure 25 for different time periods between 1896 through 1949 (USAEDNO 1986). A major bank failure occurred almost precisely at the Celotex location in 1896 (Figure 25). In addition, other past failures or "scallops" are seen in the bank line downstream from the Celotex site. In 1901, 1909, and 1922 setbacks were constructed in front of the old General Alcohol Co. and vicinity, Amesville, LA, indicating the severity of bank losses during those times. A major failure, highly likely to have been a flow slide because of the proportions of the batture loss, is indicated from the 1900 bank line in front of the General Alcohol Company complex. In the 1973-75 Mississippi River hydrographic survey (Figure 15), the presence of a secondary scour pool occurs at this same location.

Aerial photographs taken in 1977 (Figure 16), during an extremely low water period, indicate additional scallops present in the Celotex reach. Although small and insignificant looking, a scallop did exist at the Celotex failure location at that time. Other larger scallops are evident in Figure 16 downstream from the Celotex site at various places in the point bar deposit. Of particular concern to the authors is the very sharply defined scallop seen in the photograph just in front of the downstream end of the long, narrow complex of the Johns-Manville Co. (Figure 16, upper center of photo). This location corresponds to revetment ranges D-2 to D-3. Given the much smaller scallop present at the Celotex site, this larger scallop demands special attention, since the overburden is very thin at this location, and the conditions are similar to the situation at Celotex prior to the levee failure.

Historic river migration at the Greenville Bend scour pool is evident from the $-100-\mathrm{ft}(-30.5-\mathrm{m})$ NGVD scour pool in Figures $10 \mathrm{~b}$ and $11 \mathrm{~b}$ where it is seen that the pool has been growing in length, both upstream and downstream, and moving in a southeasterly direction. From the 1973-75 pool (see also hydrographic survey in Figure 15), the downstream end of the -100-ft (-30.5-m) NGVD pool was at about revetment range U-24 ( R100.4). From the 1984 hydrographic survey data in Figure 10b, the $-100 \mathrm{ft}(-30.5 \mathrm{~m})$ scour pool extended downstream to approximately range U-18 ( R100.25), an additional $800 \mathrm{ft}(244 \mathrm{~m})$ or so. The pool migration indicates increasing attack along the Greenville revetment reach in the downstream direction. Particular watchfulness appears to be warranted from about revetment range U-30 ( R100.6) to range D-15 ( R99.5). 
In summary, the evidence evaluated to date, i.e., geologic, historic bank migration and early bank lines, thalweg profiles, width/depth ratios, scour pool movement, and river profiles all indicate that future bank instability problems will be associated with the abandoned channel/point bar deposits in the Greenville Bend reach. LMN has in place a long-term monitoring program to detect bank movements and is currently monitoring this river reach for instability problems.

\section{Failure Mechanism}

Krinitzsky (1965) and Krinitzsky, Turnbull, and Weaver (1966) hypothesized a general mechanism for Mississippi riverbank failures as shown schematically in Figure 26. The first step in the bank failure process begins by scouring and erosion of the substratum sands. Loss of the sand causes further flow of the sands into the scour pool and eventually undercuts the river bank to produce instability in the upper cohesive top stratum.

The upper-bank failure progression, however, is more complex than indicated by the general model in Figure 26. If the scour in the sands is very severe indeed such as by an intense vortex, an oversteepened slope (a slope greater than the sand's angle of repose) may be rapidly generated such that retrogression is triggered according to the hypothesis advanced by Torrey (1988) and shown in Figure 27. If the top stratum is sufficiently thin and the retrogression in the underlying sands is triggered at sufficient depth, a typical flow failure develops and can produce a large loss in batture in a matter of hours. On the other hand, if the topstratum is thicker, the retrogression may not remove sufficient substratum sand to produce immediately evident instability of the top stratum at the surface of the batture. If the scour in the sands is not so severe as to trigger retrogression, it may gradually and on a seasonal basis undercut the top stratum leading to smaller shear failures which "chip away" at the batture over a number of years. The longer-term process was evident relative to the Marchand levee failure of 1983 (Dunbar and Torrey 1991).

Similarities in failure geometry in flow slides have numerically and empirically established the concept of a runout angle $\alpha$ and its control of the final geometry of a flow slide assuming no excess removal of sediment by scour occurs (Torrey 1988). A numerical analysis of the retrogressive failure mechanism in dilatant (dense) sands was originally developed by Padfield (1978) and also included in the report by Torrey, Dunbar, and Peterson (1988). Empirically, Torrey (1988) has initially demonstrated a relationship between a 10-deg runout angle $\alpha$ at various flow slide locations below Baton Rouge and the postfailure geometry at each failure. Stages of development in the retrogression mechanism are identified in Figure 27 and explained by Torrey (1988), Torrey, Dunbar, and Peterson (1988), and Torrey and Weaver (1984). 


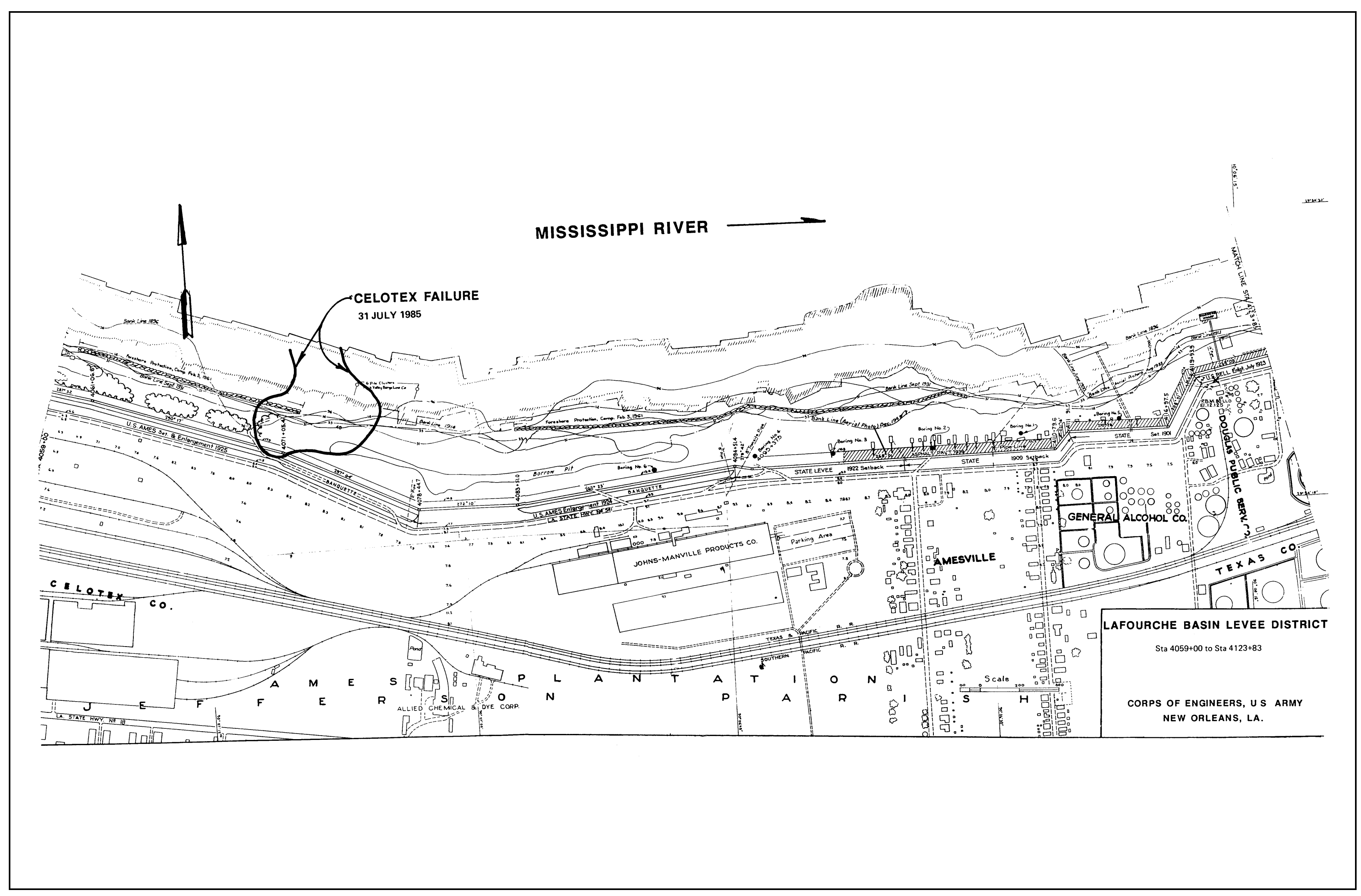

Figure 25. Historic bank lines for the Greenville revetment reach 


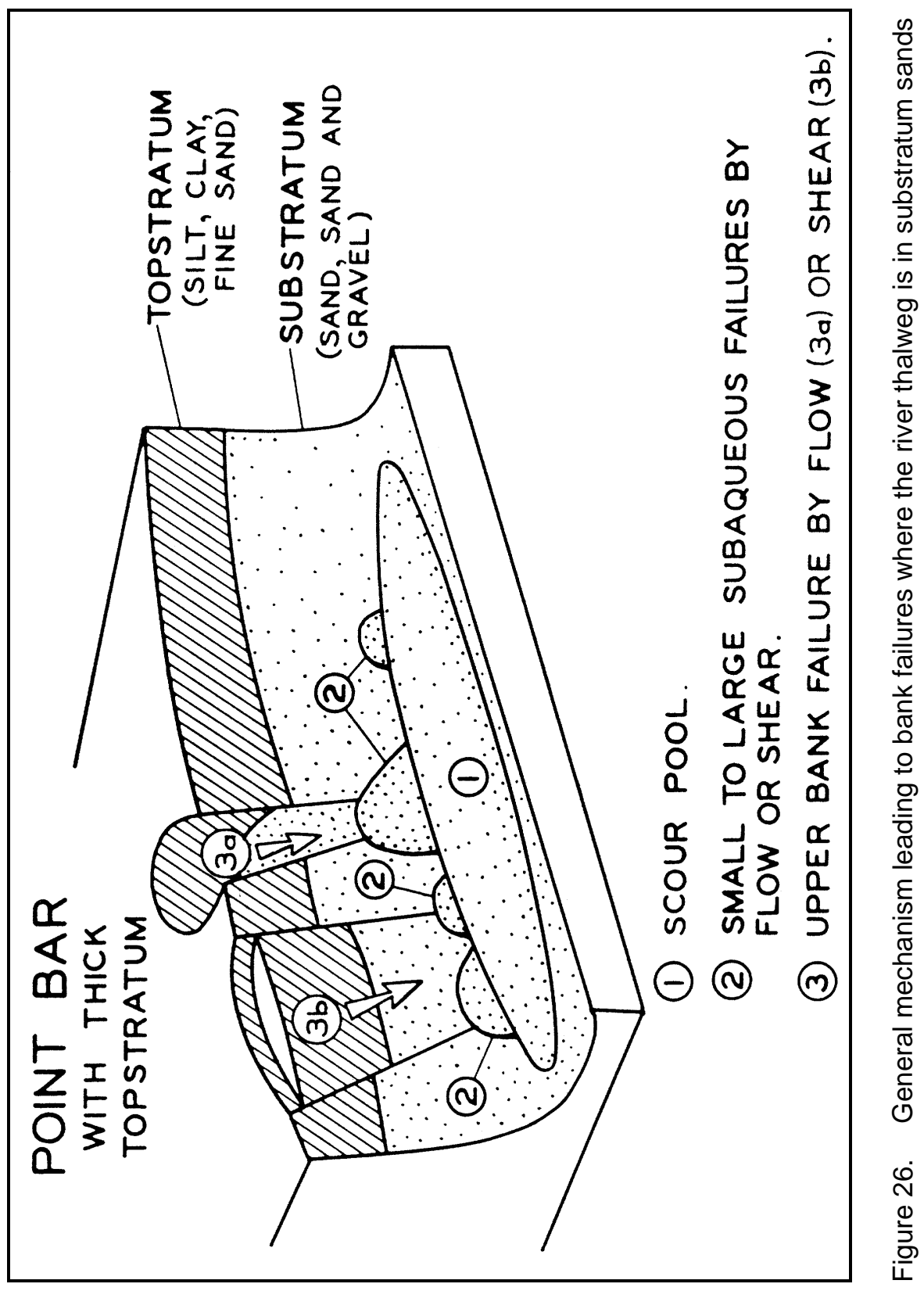




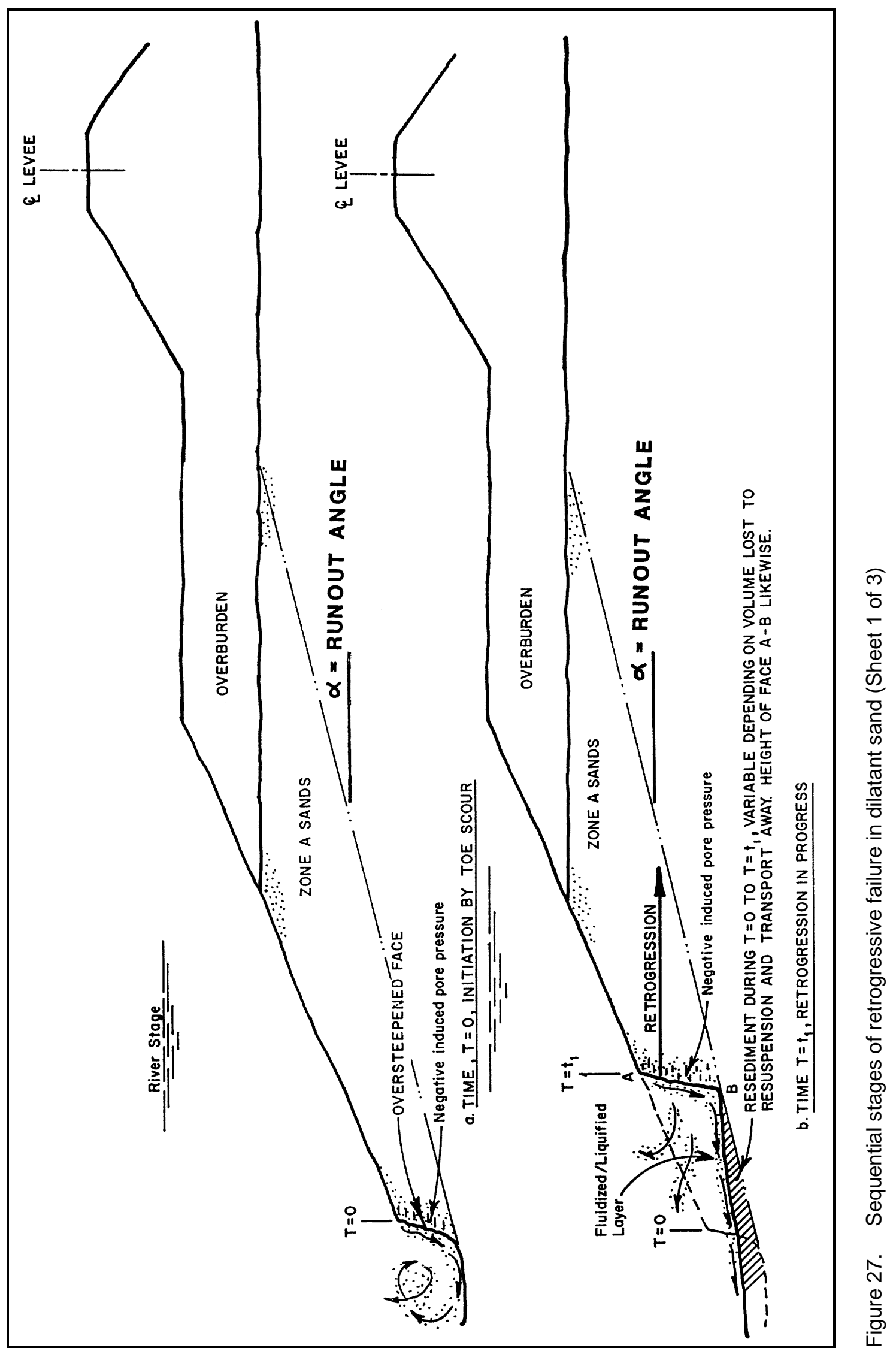




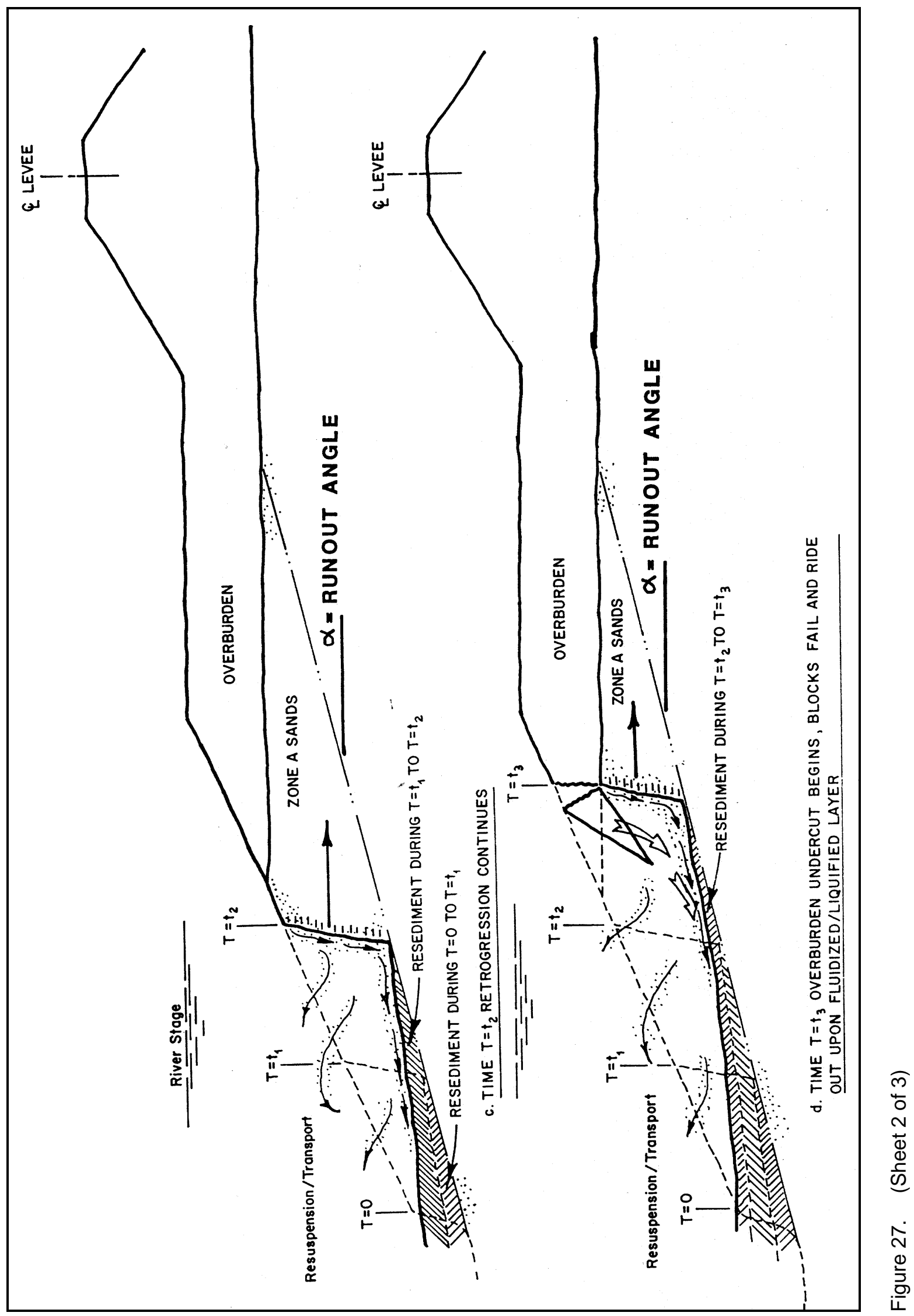




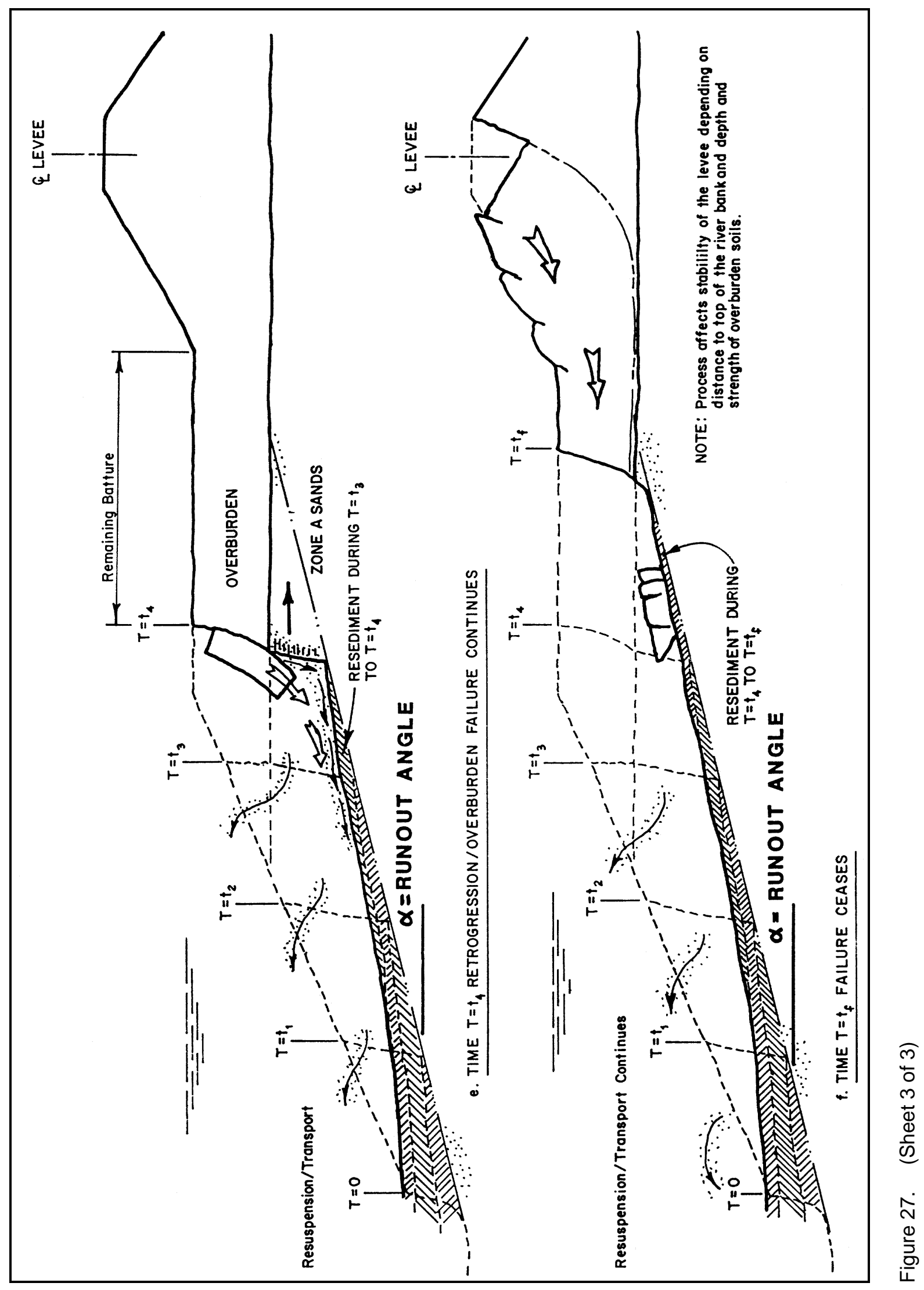




\section{Conclusions and Recommendations}

The following conclusions and recommendations are drawn from the work presented herein:

a. The geology of the failure reach consists of point bar deposits from an abandoned St. Bernard distributary channel. These deposits are primarily coarse-grained, silty sands and clean sands.

$b$. Historic data indicate that channel width at the Celotex failure reach has appreciably declined while experiencing a corresponding deepening of the channel thalweg. Selected historic profiles show the cross-sectional area of the channel throughout the failure reach has generally remained constant through historic time. A constant channel cross-sectional area and a narrowing river channel requires a channel deepening. At the Celotex site, this deepening is occurring in point bar sands.

c. Historic river migration patterns indicate the Greenville Bend revetment reach is an area of active channel migration and will continue to require continued revetment monitoring and maintenance to prevent natural lateral river migration.

d. Thalweg profiles in the Greenville Bend reach indicate the 1985 hydrographic survey was one of the deepest river channels recorded for the nearly past 100 years.

$e$. Scour pool data indicate the Greenville Bend pool has experienced historic downstream and lateral migration. The 1985 scour pool was at the maximum downstream extent.

f. A decline in width/depth ratios has occurred between the 1894 and the 1985 hydrographic survey. This decline corresponds to a narrower and deeper channel between the survey periods.

g. The Celotex batture and levee failure was the result of a flow slide in substratum sands triggered in the scour trench at about Greenville Bend revetment range U-19 (R100.25). This bank reach has been previously classified as susceptible to flow failure. 
$h$. Historic bank lines of record along the Greenville Bend revetment reach inclusive of the Celotex failure site indicate a regular history of failures and a past failure specifically at the Celotex site.

$i$. The Celotex failure occurred during low water. The reasons for the failure at this river stage are not fully understood. In general, scour pool behavior during the different seasons is not completely understood with sufficient clarity to determine the behavior of scour pools at changing river stages.

$j$. Other locations in the greater New Orleans area that are susceptible to bank instability problems include those areas where abandoned distributary channels and point bar deposits occur along the cutbank or concave side of the river. Geologic mapping shows two such locations in the area covered by this study. Distributary channels occur at Algiers Point and at Gretna. Geologic studies utilizing existing boring data should be directed toward further defining the limits of these relic distributary channels. Additionally, side-scanning sonar profiles are effective monitors of submerged slope conditions. 


\section{References}

Autin, W. J., Burns, S. F., Miller, B. J., Saucier, R. T., and Snead, J. I. (1991). "Chapter 18: Quaternary geology of the Lower Mississippi Valley." Vol K-2, The Geology of North America. The Geological Society of North America, Boulder, CO, 547-581.

Bates, R. L., and Jackson, J. A. (1987). Glossary of Geology, 3rd ed., American Geological Institute, Alexandria, VA.

Clough, G. W. (1966). "Ground water level in silty and sandy Mississippi River upper banks," Mississippi River Commission, Corps of Engineers, Vicksburg, MS. (Mr. F. J. Weaver, Lower Mississippi Valley Division, was a principal assistant in this study).

Cullinan, T. A. (1969). "Contributions to the geology of Washington and St. Tammy Parishes, Louisiana," U.S. Army Engineer District, New Orleans, LA.

Dunbar, J. B., Blaes, M. Dueitt, S., and Stroud, K. (1994). "Geological investigation of the Mississippi River deltaic plain, Report 2 of a Series," Technical Report GL-84-15, U.S. Army Engineer Waterways Experiment Station, Vicksburg, MS.

Dunbar, J. B., Blaes, M., Dneitt, S., and May, J. (1995). "Geological investiation of the Mississippi River deltaic plain, Report 3 of a Series," Technical Report GL-84-15, U.S. Army Engineer Waterways Experiment Station, Vicksburg, MS.

Dunbar, J. B., and Torrey, V. H. (1991). "Geologic, geomorphological and geotechnical aspects of the Marchand Levee failure, Marchand, Louisiana," Miscellaneous Paper GL-91-17, U.S. Army Engineer Waterways Experiment Station, Vicksburg, MS.

Eustis Engineering Company. (1984). "Geotechnical investigation: Soil stratification and foundation conditions for residential development," Report for City of New Orleans, Sewerage and Water Board of New Orleans, New Orleans, LA.

Fisk, H. N. (1944). "Geological investigation of the alluvial valley of the Lower Mississippi River," U.S. Army Corps Engineers, Mississippi River Commission, Vicksburg, MS. 
Frazier, D. E. (1967). "Recent deltaic deposits of the Mississippi River: Their development and chronology." Gulf Coast Association of Geological Societies. Transactions 17th annual meeting. San Antonio, TX.

Halbouty, M. T. (1967). Salt Domes, Gulf Region, United States and Mexico. Gulf Publishing Company, Houston, TX.

Hvorslev, M. J. (1956). “A review of the soils studies," Potamology Investigations Report No. 12-5, U.S. Army Engineer Waterways Experiment Station, Vicksburg, MS.

Kemp, E. B. (1967). "Geologic setting of New Orleans." Guidebook New Orleans, LA and vicinity field trip. The Geological Society of America and Associated Societies, Annual meetings.

Kolb, C. R. (1962). "Distribution of soils bordering the Mississippi River from Donaldsonville to Head of Passes," Technical Report No. 3-601, U.S. Army Engineer Waterways Experiment Station, Vicksburg, MS.

Kolb, C. R., and Saucier, R. T. (1982). "Engineering geology of New Orleans," Geological Society of America, Reviews in Engineering Geology 5, 75-93.

Kolb, C. R., Smith, F. L., and Silva, R. C. (1975). "Pleistocene sediments of the New Orleans-Lake Pontchartrain area," Technical Report S-75-6, U.S. Army Engineer Waterways Experiment Station, Vicksburg, MS.

Kolb, C. R., Steinriede, W. B., Krinitzsky, E. L., Saucier, R. T., Mabrey, P. R., Smith, F. L., and Fleetwood, A. R. (1968). "Geological investigation of the Yazoo Basin, Lower Mississippi Valley,” Technical Report 3-480, U.S. Army Engineer Waterways Experiment Station, Vicksburg, MS.

Kolb, C. R., and VanLopik, J. R. (1958a). "Geology of the Mississippi River Deltaic Plain," Technical Report No. 3-483, Vol 1 and 2, U.S. Army Engineer Waterways Experiment Station, Vicksburg, MS.

. (1958b). "Geological investigation of the Mississippi River-Gulf Outlet Channel," Miscellaneous Paper No. 3-259, U.S. Army Engineer Waterways Experiment Station, Vicksburg, MS.

Krinitzsky, E. L. (1965). "Geological influences on bank erosion along meanders of the Lower Mississippi River," Potamology Investigations, Report 12-15, U.S. Army Engineer Waterways Experiment Station, Vicksburg, MS.

Krinitzsky, E. L., and Smith, F. L. (1969). "Geology of backswamp deposits in the Atchafalaya Basin, Louisiana," Technical Report S-69-8, U.S. Army Engineer Waterways Experiment Station, Vicksburg, MS.

Krinitzsky, E. L., Turnbull, W. J., and Weaver, F. J. (1966). "Bank erosion in cohesive soils of the Lower Mississippi Valley," Vol 92, No. SM1, Journal of Soil Mechanics and Foundations Division, Proceedings American Society of Civil Engineers, 121-136. 
May, J. R., Britsch, L. D., Dunbar, J. B., Rodriguez, J. P., and Wlonsinski, L. B. (1984). "Geological investigation of the Mississippi River Deltaic Plain," Technical Report GL-84-15, U.S. Army Engineer Waterways Experiment Station, Vicksburg, MS.

Miller, W. (1983). "Stratigraphy of newly exposed quaternary sediments, Eastern Orleans Parish, Louisiana," Tulane Studies in Geology and Paleontology $17(3,4), 85-104$.

Montgomery, R. L. (1974). "Correlation of engineering properties of cohesive soils bordering the Mississippi River from Donaldsonville to Head of Passes, LA," Miscellaneous Paper S-74-20, U.S. Army Engineer Waterways Experiment Station, Vicksburg, MS.

New Orleans Geological Society. (1962). "Salt domes of South Louisiana," Vol 1 and 2, J. C. Stipe and J. P. Spillers, ed., New Orleans, LA. . (1983). "Salt domes of South Louisiana," Vol 3, S. J. Waguespack, ed., New Orleans, LA.

Padfield, C. J. (1978). "The stability of riverbanks and flood embankments," Final Technical Report, U.S. Army European Research Office, London, England.

Saucier, R. T. (1963). "Recent geomorphic history of the Pontchartrain Basin, Louisiana," Technical Report 16, Part A, United States Gulf Coastal Studies, Coastal Studies Institute, Contribution No. 63-2, Louisiana State University, Baton Rouge, LA.

. (1964). "Geological investigation of the St. Francis Basin,"

Technical Report 3-659, U.S. Army Engineer Waterways Experiment Station, Vicksburg, MS.

. (1967). "Geological investigation of the Boeuf - Tensas Basin Lower Mississippi Valley," Technical Report 3-757, U.S. Army Engineer Waterways Experiment Station, Vicksburg, MS.

. (1969). "Geological investigation of the Mississippi River area, Artonish to Donaldsonville, Louisiana," Technical Report S-69-4, U.S. Army Engineer Waterways Experiment Station, Vicksburg, MS.

Saucier, R. T. (1974). "Quaternary geology of the Lower Mississippi Valley," Arkansas Archeological Survey, Research Series No. 6, Fayetteville, AR.

. (1977). "The Northern Gulf Coast during the Farmdalian Substage: A search for evidence," Technical Report S-69-4, U.S. Army Engineer Waterways Experiment Station, Vicksburg, MS.

Saucier, R. T., and Kolb, C. R. (1967). "Alluvial geology of the Yazoo Basin, Lower Mississippi Valley," 1:250,000 map, U.S. Army Engineer Waterways Experiment Station, Vicksburg, MS. 
Self, R. P., and Davis, D. W. (1983). "Geology of the New Orleans area," The Compass of Sigma Gamma Epsilon 60(2), 29-38.

Smith, F. L., and Russ, D. P. (1974). "Geological investigation of the Lower Red River-Atchafalaya Basin area," Technical Report S-74-5, U.S. Army Engineer Waterways Experiment Station, Vicksburg, MS.

Smith, L. M., Dunbar, J. B., and Britsch, L. D. (1986). "Geomorphological investigation of the Atchafalaya Basin, Area West, Atchafalaya Delta, and Terrebonne Marsh, Vol 1 and 2," Technical Report GL-86-3, U.S. Army Engineer Waterways Experiment Station, Vicksburg, MS.

Snead, J. I., and McCulloh, R. P. (1984). "Geologic map of Louisiana, scale 1:500,000, Baton Rouge, LA."

Torrey, V. H., III. (1988). "Retrogressive failures in sand deposits of the Mississippi River, Report 2, Empirical evidence in support of the hypothesized failure mechanism and development of the levee safety flow slide monitoring system," Technical Report GL-88-9, U.S. Army Engineer Waterways Experiment Station, Vicksburg, MS.

Torrey, V. H., III, Dunbar, J. B., and Peterson, R. W. (1988). "Retrogressive failures in sand deposits of the Mississippi River, Report 1, Field investigations, laboratory studies and analysis of the hypothesized failure mechanism," Technical Report GL-88-9, U.S. Army Engineer Waterways Experiment Station, Vicksburg, MS.

Torrey, V. H., III, and Weaver, F. J. (1984). "Flow failures in Mississippi riverbanks." Proceedings IV International Symposium on Landslides. Vol 2, Toronto, Canada, 355-360.

Turnbull, W. J., Krinitzsky, E. L., and Weaver, F. J. (1966). "Bank erosion in soils of the Lower Mississippi Valley." Proceedings of the American Society of Civil Engineers, Journal of the Soil Mechanics and Foundation Division, 92(SM1), 121-136.

U.S. Army Corps of Engineers. (1909). "Survey of the Mississippi River, Chart Nos. 69 and 70," Mississippi River Commission, Vicksburg, MS.

U.S. Army Corps of Engineers. (1921). "Survey of the Mississippi River, Chart Nos. 69 and 70," Mississippi River Commission, Vicksburg, MS.

. (1950). "Piezometer observations at Reid Bedford Bend and indicated seepage forces," Potamology Investigations Report No. 5-4, Vicksburg, MS.

U.S. Army Corps of Engineers. (1975). "Master index, upper and lower Mississippi River surveys for period 1879-80 to 1928 and some historic maps prior to this period," Vol 2, Mississippi River Commission, Vicksburg, MS.

U.S. Army Engineer District, New Orleans. (1938). "Maps of the Mississippi River, Angola, La., to the Head of Passes," New Orleans, LA. 
U.S. Army Engineer District, New Orleans. (1952). "Mississippi River hydrographic survey, 1949-1952, Angola, La., to Head of Passes and South and Southwest Passes and Pass A Loutre," New Orleans, LA.

. (1965). "Mississippi River hydrographic survey, 1961-1963, Black Hawk, La., to Head of Passes and South and Southwest Passes and Pass A Loutre," New Orleans, LA.

. (1976). "Mississippi River hydrographic survey, 1973-1975, Black Hawk, La., to Head of Passes and South and Southwest Passes and Pass A Loutre," New Orleans, LA.

. (1984). "Mississippi River levees, Item M-181.1 to 180.2-L,

Marchand Levee setback, final report," New Orleans, LA (internal report, unpublished).

. (1986). "Mississippi River levees, Item M-100.4-R, Celotex Levee and Batture restoration, final report," New Orleans, LA (internal report, unpublished).

. (1988). "Mississippi River hydrographic survey, 1983-1985, Black Hawk, La., to Head of Passes and South and Southwest Passes and Pass A Loutre," New Orleans, LA (internal report, unpublished).

Wallace, W. E. (1966). "Fault and salt map of South Louisiana," Gulf Coast Association of Geological Societies, Vol 16. 


\section{Appendix A Environments of Deposition}

\section{General}

This appendix provides a general description of the environments of deposition which produced the surface and subsurface geology encountered in the study reach. The distribution of surface deposits is shown by the geologic map in Figure 4 of the main text. Subsurface limits of the various depositional environments are shown by the cross sections in Figures 5a through 5k. A geologic legend is presented in Figure 51 that identifies symbols used in the geologic cross sections.

In addition to the general descriptions of the individual environments of deposition, this appendix also provides a very generalized indication of the engineering properties for each environment. Correlation of engineering properties and soil types to the different environments of deposition is based primarily on work by Kolb (1962) ${ }^{1}$ and is summarized in Table A1. Additionally, Montgomery (1974) expanded upon Kolb's original work for several of the major depositional environments which form the bulk of the land area in the deltaic plain. Montgomery's work is summarized in Table A2 and provides further engineering data on the following selected environments of deposition: natural levee, point bar, backswamp, prodelta, intradelta, and interdistributary deposits.

In terms of their engineering significance, the biggest contrast occurs between the Pleistocene and Holocene age sediments as shown by the engineering data in Table A1. Pleistocene sediments have higher cohesive strengths, lower water contents, and are much denser than Holocene soils. Holocene deposits in contrast are less consolidated, have higher water contents, and are more variable in density.

The biggest contrast in Holocene soils occurs between the high- and lowenergy depositional environments. High-energy environments are generally associated with maximum fluvial and/or wave activity and are mainly composed of coarse-grained sediments. These environments include point bar, substratum, abandoned course, abandoned distributary, beach, nearshore gulf, estuarine/bay

1 References are listed following the main text. 
sound, and intradelta deposits (Table A1). Low-energy environments are composed primarily of fine-grained sediments and include marsh, swamp, natural levee, prodelta, and interdistributary. Only the environments of deposition that are present in the study area are examined in the following section. The environments are presented and described by their order and distribution of occurrence. Deltaic environments not present in the study area but identified in Table A1 are described in further detail by Kolb (1962) or Kolb and Van Lopik (1958a,b) for readers desiring further information.

\section{Surface Environments of Deposition}

\section{Natural levee}

Natural levees are vertical accretion deposits formed when the river overtops its banks during flood stage and sediment suspended in the flood flow is deposited immediately adjacent to the channel. The resulting landform is a low, wedge-shaped ridge decreasing in thickness away from the channel. The limits of natural levee deposits in the study area are shown in Figure 4 of the main report. Natural levee deposits are mapped in Figure 4 with the underlying environment of deposition (i.e., interdistributary, point bar, or inland swamp). Natural levee deposits cover approximately 40 percent of the study area and involve the Mississippi River and abandoned distributary channels from the active St. Bernard delta complex (i.e., Bayou des Familles-Barataria, Metairie Bayou, Bayou Sauvage, and two unnamed bayous).

Natural levee widths in the study area vary from about 3/4 to approximately 2 miles wide along the Mississippi River, and between 1/4 and 1/2 mile wide along the abandoned St. Bernard distributary channels (Figure 4). Natural levees are thickest adjacent to the main channel, ranging from 10 to $20 \mathrm{ft}$ in thickness (Figures 5a to 5k). Their thickness decreases away from the river, eventually merging with inland swamp deposits.

Natural levee deposits in the study area are composed primarily of clay and silt with minor sand lenses. Soils associated with natural levee deposits are identified in Figures 5a through 5k of the main report. These deposits are generally coarser-grained near the channel, composed of silt (ML) and silty clay (CL), and become finer-grained (i.e., $\mathrm{CL}$ and $\mathrm{CH}$ ) further from the river. Color varies from reddish brown or brown near surface to grayish brown, and medium to dark gray with depth. Darker colored natural levee soils are due to the higher organic content. Organic content is generally low and is in the form of small roots and occasionally disseminated wood fragments. Larger wood fragments are uncommon as oxidation has reduced organic materials to a highly decomposed state. Frequently associated with natural levee deposits are small calcareous nodules, formed as a result of groundwater percolating through the permeable soils and precipitated from solution. Natural levee soils are welldrained, have low-water contents, and generally have a stiff to very stiff consistency (Tables A1 and A2). 


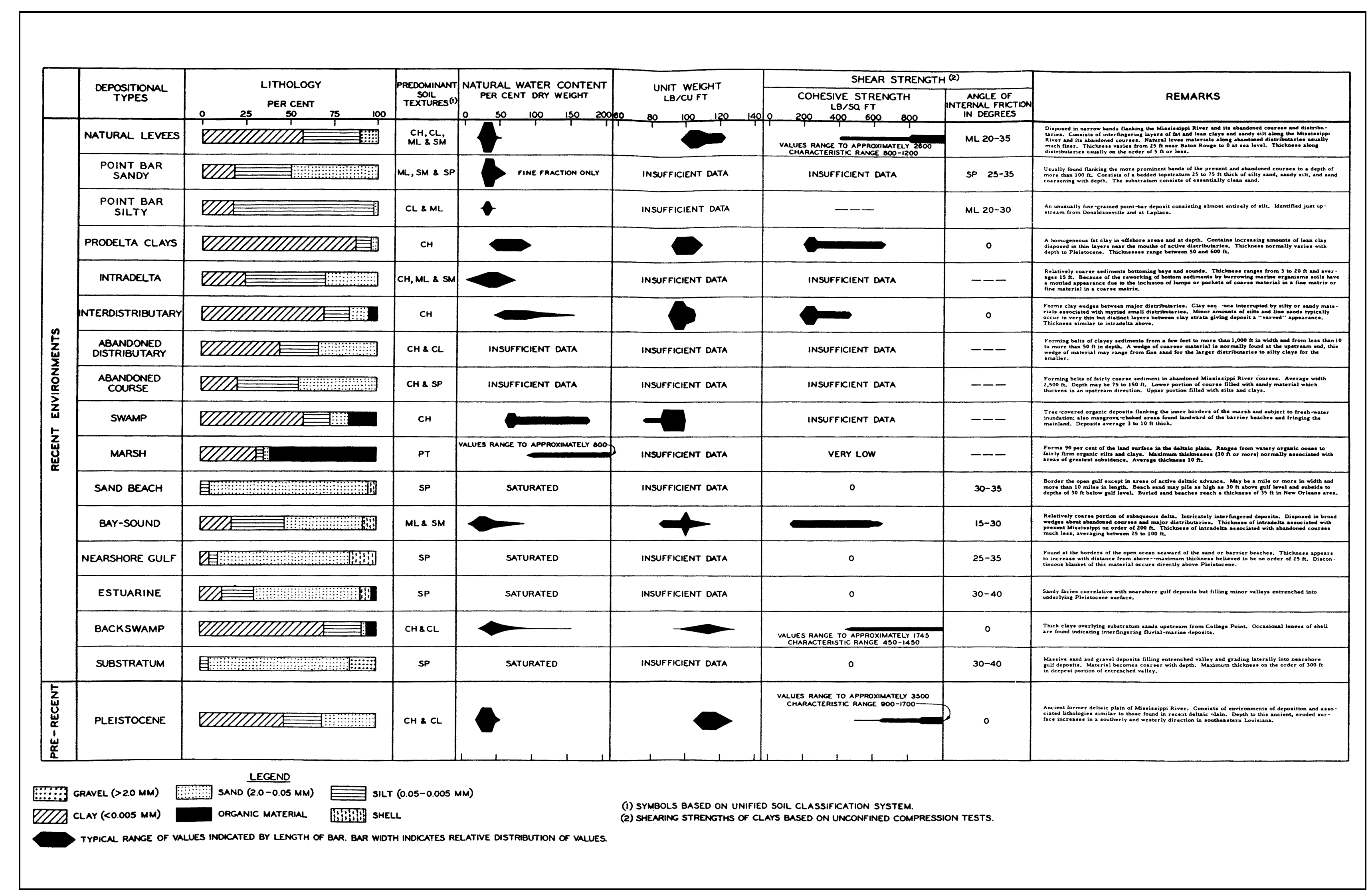

Table A1. Engineering Properties of Depositional Environments from the Mississippi River Deltaic Plain (from Kolb 1962) 


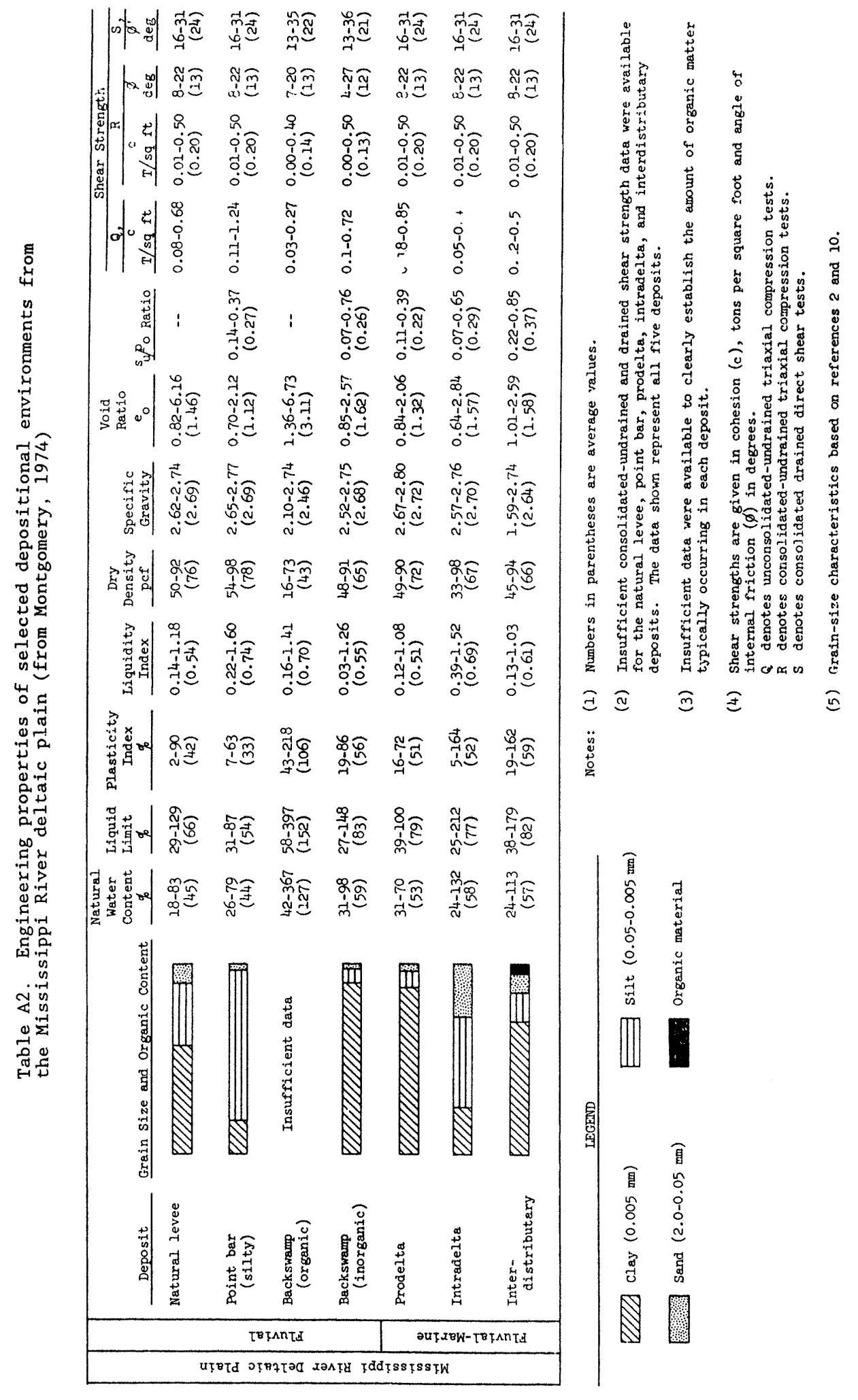




\section{Inland swamp}

Before describing characteristics of inland swamps and their distribution in the study area, a clarification of terminology is in order. Usage of the term inland swamp is restricted to the deltaic plain, whereas the term backswamp is restricted to the Mississippi River alluvial valley. Mapping by May et al. (1984) adopted the usage of the term inland swamp and defined the upvalley margin of this environment. Inland swamps are not bounded by valley margins or older meander belt ridges as in the alluvial valley. Instead, inland swamps in the deltaic plain are areas of high ground and woody vegetation formed because of the high sediment rates from advancing distributary channels.

Kolb (1962) recognized that the term backswamp was inappropriate for the deltaic plain and had reservations about using this term to describe swamp sediments below Donaldsonville, LA. May et al. (1984) have placed the boundary between backswamp and inland swamp near the vicinity of Houma, LA. The boundary separating the two swamp types occurs at the junction of Bayou Teche and Bayou LaFourche, two former Mississippi River courses. Consequently, the summary descriptions and engineering properties in Tables A1 and A2 for backswamp are more appropriate to inland swamp as the samples were derived primarily from inland swamp sediments. The primary distinction here is in process and the ultimate nature of the sediments derived by these processes. In theory, inland swamp sediments are considered to be much finer-grained than backswamp sediments since they are transported by smaller-scale distributary channels to locations on the deltaic plain that are well removed from the main channel. As shown by Figure 3 in the main report, primary Mississippi River flow was not confined to a single main channel during the period of active Holocene delta building but rather was shared by several smaller major distributary courses.

Inland swamps are vertical accretion deposits that receive sediment during times of high-water flow, when the natural levees are crested and suspended sediment in the flood waters is deposited in areas well removed from the main distributary channel. Inland swamp environments are low, often poorly drained, tree-covered areas flanking the main distributary channel. Inland swamps are low areas that are settling basins for flood flow and sediment, and represent one of the final stages in land building by the passing delta front. Sediment supply is sufficient to elevate the land surface to above sea level and allow woody vegetation to develop and become stable.

Inland swamps are the dominant surface environment in the study area and comprise approximately 50 percent of the Holocene deposits depicted in Figure 4. The surface of the inland swamp environment begins at about the $0 \mathrm{ft}$ NGVD elevation. These deposits are approximately 10 to $15 \mathrm{ft}$ thick with the base of this sequence grading into marsh and interdistributary sediments between -10 to $-15 \mathrm{ft}$ NGVD (Dunbar et al. 1994).

Inland swamps are composed of uniform, very fine-grained soils, primarily silty clay (CL) and clay (CH). Sand (SM and SP) and silt (ML) may be present but is considered a minor constituent of the total depositional sequence (Table A1 and A2, and Figures 5a through 5k of the main report). These deposits typically contain moderate to high organic contents in the form of 
decayed roots, leaves, and wood. Disseminated pyrite is a common but a very minor constituent of these soils and is commonly found in more poorly drained areas which promotes reducing conditions. Inland swamp soils may become well drained during times of low water and undergo short periods of oxidation, lending a mottled appearance to the soil. Inland swamp soils are gray, dark gray, or occasionally black. Inland swamp soils have generally high-water contents, between 30 and 90 percent, as shown by Tables A1 and A2 (backswamp environment).

\section{Point bar}

Point bar deposits are lateral accretion deposits formed as a river migrates across its flood plain. River channels migrate across their floodplain by eroding the outside or concave bank and depositing a sandbar on the inside or convex bank. With time the convex bar grows in size and the point bar is developed. Associated with the point bar are a series of arcuate ridges and swales. The ridges are formed by lateral channel movement and represent relic lateral bars separated by low lying swales. The swales are locations for fine-grained sediments to accumulate. Point bar deposits are as thick as the total depth of the river that formed them. These deposits become coarser-grained with increasing depth. Maximum grain size is associated with the river's bedload (coarse sand and fine gravel) while the fine-grained soils occur near the surface. The basal or coarse-grained portion of the point bar sequence is deposited by lateral accretion while the fine-grained or upper portion of the point bar sequence is deposited by vertical accretion.

Point bar deposits in the study area are considered to be young, generally less than 3,500 years old. They began forming along Bayou des Familles-Barataria when the St. Bernard delta system was active but didn't fully develop along the main river until the present Mississippi River course began forming less than 1,000 years before the present.

Soil types in a point bar sequence grade upward from coarse-grained sands and fine gravels near the base to clays near the surface. These deposits are variable, but in the study area are generally composed of at least 50 percent poorly graded fine sand (Figures 5a through $5 \mathrm{~h}$ and Tables A1 and A2). Point bar deposits are separated into two distinct units, a predominantly fine-grained upper sequence or point bar top stratum, and a coarse-grained lower sequence or point bar substratum. Soil types associated with each unit are identified in the geologic sections in Figures 5a through $5 \mathrm{f}$ of the main report.

\section{Abandoned course}

An abandoned course as the name implies is a relic fluvial course that is abandoned in favor of a more hydraulically efficient course. An abandoned course contains a minimum of two meander loops and forms when the river's flow path is diverted to a new position on the river's floodplain. This event usually is a gradual process that begins by a break or a crevasse in the river's natural levee during flood stage. The crevasse forms a temporary channel that may, over time, develop into a more permanent channel. Eventually, the new 
channel diverts the majority of flow and the old channel progressively fills. Final abandonment begins as coarse sediment fills the abandoned channel segment immediately downstream from the point of diversion. Complete filling of the abandoned course is a slow process that occurs by overbank deposition. The complete filling process may take several hundreds or even thousands of years to complete.

The Bayou des Familles-Barataria abandoned course is a prominent physiographic feature that extends due south from the Mississippi River at approximately river mile 100 (Figures 1 and 4 of the report). The abandoned course extends well beyond the limits of the study area and continues south to Barataria Bay (May et al. 1984, Dunbar et al. 1994). It contains broadly developed natural levees which are easily identified on aerial photography and topographic maps. Well developed natural levees and a meandering plan form distinguish the abandoned course from its short lived predecessor, the crevasse channel.

Boring information from the greater New Orleans area indicates channel fill from the Bayou des Familles abandoned course consists primarily of thick sand deposits capped by a thin layer of silt and clay. Detailed boring information from the abandoned course at its confluence with the Mississippi River is presented in Figures $5 \mathrm{c}$ and $5 \mathrm{i}$ of the main report. Engineering properties of abandoned course sediments are not sufficiently categorized in Table A1 due to lack of boring data. However, these sediments are considered to be similar in composition to sandy point bar deposits for which data are present.

\section{Abandoned distributary channel}

Distributary channels are channels that diverge from the trunk channel dispersing or "distributing" flow away from the main course. By definition, distributary channels do not return flow to the main channel on a delta plain (Bates and Jackson 1987). Distributary channels originate initially as crevasse channels during high flow periods when the main channel is unable to accommodate the larger discharge. If the flood is of sufficient duration, a permanent distributary channel is soon established through the crevasse. Abandonment of a distributary channel or distributary network occurs either as a major course shift upstream or the distributary becomes over extended and loses its gradient advantage in favor of a much shorter distributary channel. Complete abandonment usually occurs because of an improved gradient advantage by the new distributary.

Distributary channel abandonment closely parallels the abandonment of a course. During abandonment, the base of the channel is filled with poorly sorted sands, silts, and organic debris. As the channel continues to fill, the flow velocities are decreased, and the channel is filled by clay, organic ooze, and peats. Abandoned distributaries in the study area are approximately their original width, but only a fraction of their original depth due to infilling. Abandoned distributary channels in the study area are Metairie Bayou, Bayou Sauvage, and two unnamed distributaries that intersect the Mississippi River on the east and west banks (Figure 4). These distributary channels have all been partially or completely filled with sediments. 
Often the distal ends of abandoned distributaries have been buried due to subsidence, destroyed by coastal erosion, or closer to the trunk channel, buried by later natural levee deposits (Figure 4). Metarie Bayou in the northern portion of the study area has been buried by later Mississippi River natural levee deposits and altered by the historic activities of man north of the river. Natural levees are ideal for urban development since these areas are topographically higher than the surrounding area.

Abandoned distributaries are recognized on aerial photographs by their natural levees and the urban development associated with these levees. In the subsurface, distributary sediments are recognized by soil types (Table A1) and sedimentary structures characteristic of channel fill deposits. Engineering properties of abandoned distributary sediments are not sufficiently categorized in Table A1 due to lack of boring data. Upper channel fill consists of parallel and wavy laminated silts and silty clays, interbedded with highly burrowed clays with high-water contents. Distorted bedding, slump structures, organic layers, and minor shell material are also common in abandoned distributary deposits.

\section{Freshwater marsh}

In the southwestern portion of the study area there is an area of freshwater marsh, a nearly flat expanse where grasses and sedges are the only vegetation. Organic sedimentation plays an important role in the formation of marsh deposits. Peats, organic oozes (mucks), and humus are formed as the marsh plants die and are buried. Decay is largely due to anaerobic bacteria in stagnant water. Vegetative growth and sedimentation maintain the surface elevation at a fairly constant level, and the marsh deposits thicken as a result of subsidence over time. When marsh growth fails to keep pace with subsidence, the marsh surface is eventually inundated by water.

Peats are the most common form of marsh strata remains, and they consist of black fibrous masses of decomposed plants. Detrital organic particles, carried in by marsh drainage, and vegetative tissues form the mucks. Mucks are watery oozes that can support little or no weight. Sedimentation occurs in the marsh when floodwater overtops the natural levees, depositing clays and silts onto the marsh surface. Sediments are also transported to the marsh during lunar tides, wind tides, and hurricane tides when sediment laden marine waters inundate the marsh surface.

Marsh sediments are found in the subsurface as peats (Figures $5 \mathrm{~b}$ through $5 \mathrm{k}$ ) and represent a time during the Holocene where the land surface was at sea level and supporting marsh vegetation. Often marsh deposits grade vertically upward in a prograding delta system into inland swamp, followed by natural levee deposits. The reverse sequence is also true (i.e., marsh, natural levee, inland swamp, marsh). Engineering properties of marsh sediments are identified in Table A1. 


\section{Subsurface Environments of Deposition}

\section{Interdistributary}

Interdistributary deposits are sediments deposited in low areas between active distributary channels, usually under brackish water conditions. Sediment laden waters overtop the natural levees of distributary channels during flood stage and deposit the coarsest sediment (silt) near the channel. The finer sediment (silty clay and clay) is transported away from the active distributary channel and settles out of suspension as interdistributary deposits. In this manner, considerable thicknesses of clay are deposited as the distributary builds seaward. Interdistributary clays often grade downward into prodelta clays and upward into the highly organic clays of swamp and marsh deposits.

Interdistributary deposits are found throughout the study area in the subsurface (Figure $5 \mathrm{~b}$ through $5 \mathrm{k}$ of the main report). These deposits range in thickness from 30 to $60 \mathrm{ft}$ and start between 0 to $-10 \mathrm{ft}$ NGVD as shown by the cross sections in Figures $5 \mathrm{~b}$ through $5 \mathrm{k}$. Interdistributary deposits consist of saturated gray clays which are highly bioturbated and contain some silt laminae. Shell fragments and minor amounts of organic debris are also commonly distributed throughout the interdistributary sequence as shown by Tables A1 and A2.

\section{Buried beach}

Interdistributary sediments associated with Metairie Bayou, an abandoned St. Bernard distributary in the northern edge of the study area, overlie and grade laterally with buried beach deposits. Buried beach deposits are part of the Pine Island Beach trend, an early Holocene beach trend associated with active sedimentation from the Pearl River (Saucier 1963). Approximately 5,000 years ago, when sea level was slightly lower than the present, longshore drift created a southwest to northeast trending offshore spit or barrier beach complex in the New Orleans area. Sediments forming the spit were derived from sandy fluvial sediments transported by the Pearl River. This spit originated at the river's mouth and extended southwest to the vicinity of New Orleans. This buried beach complex forms the southern shore of Lake Pontchartrain and acted as a natural barrier for filling of Lake Pontchartrain by advancing distributary channels during the active St. Bernard stage of delta growth.

Metairie Bayou (Figure 4) follows the seaward edge of the Pine Island Beach trend and was blocked from entering the main body of Lake Pontchartrain by the higher topography of the relic beach. Instead, Metairie Bayou follows the relic beach trend northeast toward the coastal mainland as the Bayou Sauvage distributary channel. Coastal drainage into Lake Pontchartrain from the Pleistocene uplands breached the beach ridge and formed "The Rigolets," a pass into Lake Pontchartrain at the eastern edge of the deltaic plain (Figure A1 from Saucier 1963). 


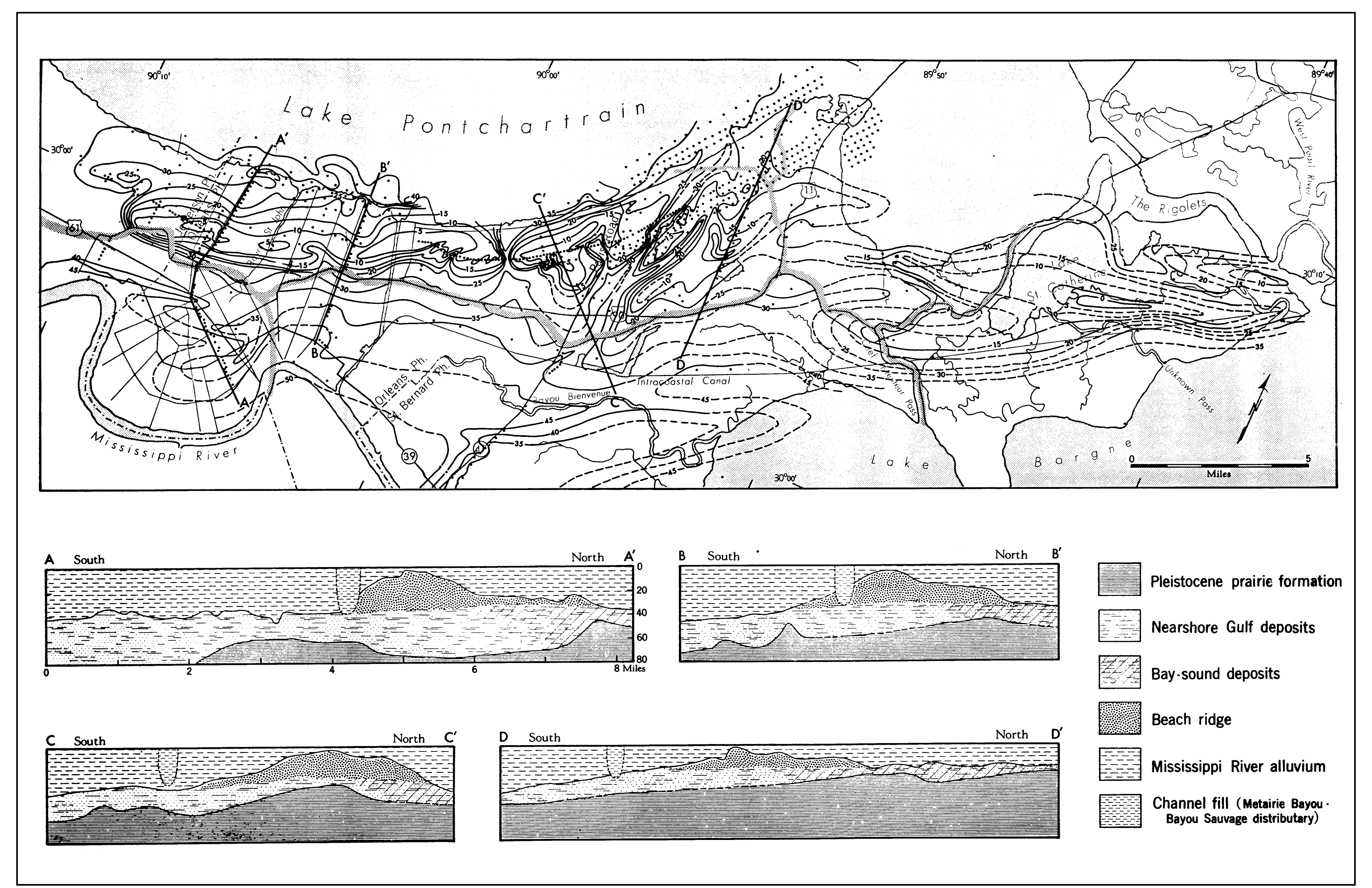

Figure A1. Topography of the buried Pine Island beach trend (Saucier 1963) 
The beach trend grades laterally into intradelta and abandoned distributary deposits (Figure A1). Boring data identifies the buried beach deposits as consisting of uniform, fine to medium grained, quartz sand, ranging in color from gray to tan, and white upon exposure at the surface (Saucier 1963). Beach sand is generally well sorted and contains shell fragments.

\section{Intradelta}

Intradelta deposits form at the mouth of distributary channels and consist of coarse-grained or sandy sediments. At the mouth of a distributary, the water velocity decreases upon entering open water, depositing coarse-grained sediments from suspension as distributary mouth bars. The coarse sediments are deposited on the bar crest or as fans along the sides of the bars. As the distributary is built seaward, it may cut through or split around the bar. The process is then repeated in each of the smaller, branching distributary channels. These deposits interfinger and merge with interdistributary clays.

Intradelta deposits are identified in the subsurface in borings near the Mississippi River (Figures 5a, 5b, 5e, and 5g). They consist primarily of clean sands and silty sands with some silts. Intradelta deposits are thickest nearer the distributary channels or channel source areas. Engineering properties of intradelta sediments are summarized in Tables A1 and A2.

\section{Nearshore gulf}

Nearshore gulf deposits are generally coarse-grained sediments formed by the transgression and interaction of the rising Holocene sea level with the drowned Pleistocene surface. Nearshore gulf deposits represent sediments eroded, transported, and deposited at the land/sea level interface, often at maximum wave energy and under storm conditions. These deposits generally consist of coarse-grained sediments and are primarily characterized by sand and shell hash. Available engineering data is presented in Table A1. The subsurface distribution of this depositional environment is shown by the cross sections in Figures $5 \mathrm{a}$ through $5 \mathrm{k}$ of the main report. Generally, this environment directly overlies the Pleistocene surface throughout the deltaic plain region.

\section{Estuarine and bay sound}

Both of these environments are marine and are a minor environment in the subsurface (see Figures 5a through 51). Both of these environments directly overlie the Pleistocene surface. These two environments were formed early during the Holocene, or perhaps even Late Pleistocene, when sea level advanced onto the Pleistocene surface. As sea level advanced, it drowned the existing Pleistocene drainage network and created small estuaries and bays.

An estuary is a river valley where fresh water comes into contact with sea water (Bates and Jackson 1987). A bay sound is a partly enclosed brackish water body which is sheltered from direct access to the Gulf and is dominated by both fluvial and marine processes. Since the bay sound is partly restricted from 
the Gulf, the depositional energy and associated geomorphic processes are less severe than those associated with the nearshore gulf environment. Sediments deposited within an estuary or bay sound environment have a much greater range in grain size than sediments deposited within the nearshore gulf environment (Table A1). Silt and clay are usually more common within the estuarine and the bay sound environment than the nearshore gulf environment as shown by Table A1.

\section{Substratum}

Substratum or "braided stream/outwash plain" deposits related to glacial melting and sea level rise are not present in the study area. Substratum deposits as identified in this report are coarse-grained sediments associated with the point bar environment. The term substratum as used in this report and on the cross sections in Figures 5a through 5k is used in conjunction with and is a modifier of the point bar environment. Point bar substratum deposits are typically the lateral accretion or coarse-grained component of the point bar sequence. The upper boundary occurs at the base of the fine-grained or vertical accretion component of the point bar sequence and is defined by the first nearly continuous silty sand (SM) contact.

\section{Pleistocene}

Pleistocene deposits are present only in the subsurface and are correlative to the Prairie Formation. The Prairie Formation is the youngest of Fisk's (1944) four major interglacial fluvial and deltaic sequences and was deposited during Sangamonian time, approximately 70,000 to 125,000 years ago. The Prairie Formation is similar in origin to the Holocene age deposits which overlie the Prairie. They were both envisioned by Fisk (1944) as fining upward from a coarse-grained substratum to a fine-grained top stratum. Both are products of rising sea level and deposition following continental glaciation. However, detailed analysis of glacial chronology from the midwest, combined with detailed geologic mapping from the Lower Mississippi Valley in recent years, indicates that the four-cycle model of Pleistocene glaciation and the accompanying interglacial deposition are an oversimplification (Autin et al. 1991). Recent studies indicate that the geology of the Prairie Formation in the study area is highly complex (Cullinan 1969; Kolb, Smith, and Silva 1975; Saucier 1977; Dunbar et al. 1994).

Lithologic and stratigraphic data on the Prairie Formation are based on surface exposures north of Lake Pontchartrain in St. Tammy, St. Helena, Tangipahoa, and Washington Parishes, Louisiana, and foundation engineering borings from the greater New Orleans metropolitan area. Pleistocene age soils outcropping on the north shore of Lake Pontchartrain were mapped by Cullinan (1969) as being typically light gray, light brown, or yellowish orange in color and composed of muddy, fine sandstones or fine to very fine sandy siltstones. Beneath the Holocene sediments in the New Orleans area, numerous engineering borings drilled into the Pleistocene surface identify the Prairie as being composed primarily of clay and silty clay and having the following characteristics (Kolb and VanLopik 1958a,b, Kolb 1962): (a) oxidized tan, yellow, or 
greenish gray color, (b) a marked decrease in water content, (c) distinctive stiffening in soil consistency and a general increase in shear strength, and (d) the presence of concretions. Pleistocene age soils forming the subsurface in the New Orleans area are usually easily distinguished from Holocene age soils by their sharp contrast in engineering properties, lithology, and stratigraphy. Soil color, water content, and shear strength are the most diagnostic criteria distinguishing Pleistocene from Holocene soils (Table A1).

Between the fine-grained Pleistocene sediments beneath the New Orleans area and the more coarse-grained sediments that outcrop at the surface north of Lake Pontchartrain, there is a transition which may be due to variations within environments of deposition or stratigraphy during the Late Pleistocene. The New Orleans area Pleistocene soils may have formed under several depositional settings, including inland swamp, interdistributary, bay sound, and/or estuarine environments, while the coarser-grained soils north of Lake Pontchartrain are perhaps related to mainland beach and terrestrial fluvial environments draining the Pleistocene uplands. The Prairie surface is a highly complex stratigraphic sequence that consists of multiple depositional facies which formed over a period of several tens of thousands of years, followed by thousands of years of subaerial oxidation and erosion during maximum glacial episodes and lowered sea levels, and then later burial by Holocene sediments.

The Pleistocene surface dips gently to the south and southwest at about 3 to $5 \mathrm{ft}$ per mile (Figure 6 of the main report). Elevations on the Pleistocene surface range from approximately $-60 \mathrm{ft}$ NGVD in the northern portions of the study area to more than -100 ft NGVD south of the Mississippi River. The base of the Prairie Formation beneath the Celotex failure site occurs somewhere between elevation -500 and $-600 \mathrm{ft}$ NGVD (Cullinan 1969). 


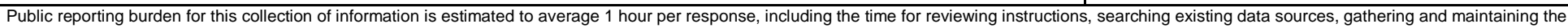

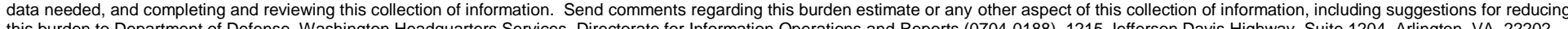

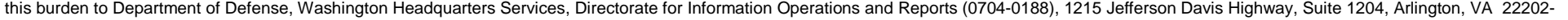

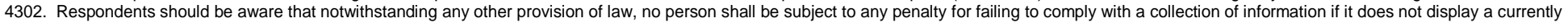
valid OMB control number. PLEASE DO NOT RETURN YOUR FORM TO THE ABOVE ADDRESS.

\section{\begin{tabular}{l|l|l} 
1. REPORT DATE (DD-MM- $Y Y Y Y)$ & 2. REPORT TYPE & 3. DATES COVERED (FrOm - TO)
\end{tabular}}

December 1999

Final report

\section{TITLE AND SUBTITLE}

A Case History of Embankment Failure: Geological and Geotechnical Aspects of the

Celotex Levee Failure, New Orleans, Louisiana

5a. CONTRACT NUMBER

5b. GRANT NUMBER

5c. PROGRAM ELEMENT NUMBER

6. AUTHOR(S)

Joseph B. Dunbar, Victor H. Torrey III, Lillian D. Wakeley

5d. PROJECT NUMBER

5e. TASK NUMBER

5f. WORK UNIT NUMBER

\section{PERFORMING ORGANIZATION NAME(S) AND ADDRESS(ES)}

8. PERFORMING ORGANIZATION REPORT NUMBER

U.S. Army Engineer Research and Development Center

Geotechnical Laboratory

Technical Report GL-99-11

3909 Halls Ferry Road

Vicksburg, MS 39180-6199

9. SPONSORING / MONITORING AGENCY NAME(S) AND ADDRESS(ES)

U.S. Army Engineer Division, Mississippi Valley

Vicksburg, MS 39180-0080

U.S. Army Corps of Engineers Civil Works Research and Development Program NUMBER(S)

Risk Analyses for Dam Safety

12. DISTRIBUTION / AVAILABILITY STATEMENT

Approved for public release; distribution is unlimited.

\section{SUPPLEMENTARY NOTES}

\section{ABSTRACT}

A section of levee along the Mississippi River near Marrero, LA, failed in a nonflood-related event. This report addresses the factors that contributed to that failure, which involved nearly $230,000 \mathrm{cu} \mathrm{m}$, and the mechanisms of failure. The data examined during research on the causes of levee failure included geologic setting, historic bank migration and previous bank lines, thalweg profiles, width/depth ratios, scour pool movement, and river profiles. The geology within the pertinent river reach and Holocene chronology of changes in the river channel profile were critically important factors in revealing the cause of levee failure. The Marrero or Celotex failure occurred within sandy point-bar deposits from a former distributary channel of the St. Bernard delta system. During historic time, the river channel narrowed appreciably in the failure reach, while maintaining a near-constant cross-sectional area. The general failure mechanism involved scouring and erosion of sand from the toe of the river bank, causing an over-steepened slope and resultant instability of the upper bank. That is, severe scour at the toe resulted as the thalweg deepened through the sandy substratum. Flow failure in the sands then led to loss of the upper bank or batture. Thus, the location of the failure was controlled by the nature of the geologic deposits beneath the levee

(Continued)

\section{SUBJECT TERMS}

Delta, Embankment failure, Engineering geology, Levee failure, Mississippi River bank stability, Point-bar deposits, Retrogressive failure, Riverbank stability, River erosion, River morphology

\begin{tabular}{|c|c|c|c|c|c|}
\hline \multicolumn{3}{|c|}{ 16. SECURITY CLASSIFICATION OF: } & \multirow{2}{*}{$\begin{array}{l}\text { 17. LIMITATION } \\
\text { OF ABSTRACT }\end{array}$} & \multirow{2}{*}{$\begin{array}{l}\text { 18. NUMBER } \\
\text { OF PAGES } \\
114\end{array}$} & \multirow{2}{*}{$\begin{array}{l}\text { 19a. NAME OF RESPONSIBLE PERSON } \\
\text { 19b. TELEPHONE NUMBER (include area } \\
\text { code) }\end{array}$} \\
\hline $\begin{array}{l}\text { a. REPORT } \\
\text { UNCLASSIFIED }\end{array}$ & $\begin{array}{l}\text { b. ABSTRACT } \\
\text { UNCLASSIFIED }\end{array}$ & $\begin{array}{l}\text { c. THIS PAGE } \\
\text { UNCLASSIFIED }\end{array}$ & & & \\
\hline
\end{tabular}


14. ABSTRACT (Concluded)

combined with progressive deepening of the river channel at this location. Other locations along the lower Mississippi River, having similar geologic settings of ancient distributary deposits on the concave side of the river, are likely to be susceptible to the same type of levee failure. 
Destroy this report when no longer needed. Do not return it to the originator. 